\title{
RECONNAISSANCE OF BENTHIC INVERTE- BRATES FROM TRIBUTARY STREAMS OF THE YAMPA AND NORTH PLATTE RIVER BASINS, NORTHWESTERN COLORADO
}

\section{U.S. GEOLOGICAL SURVEY}

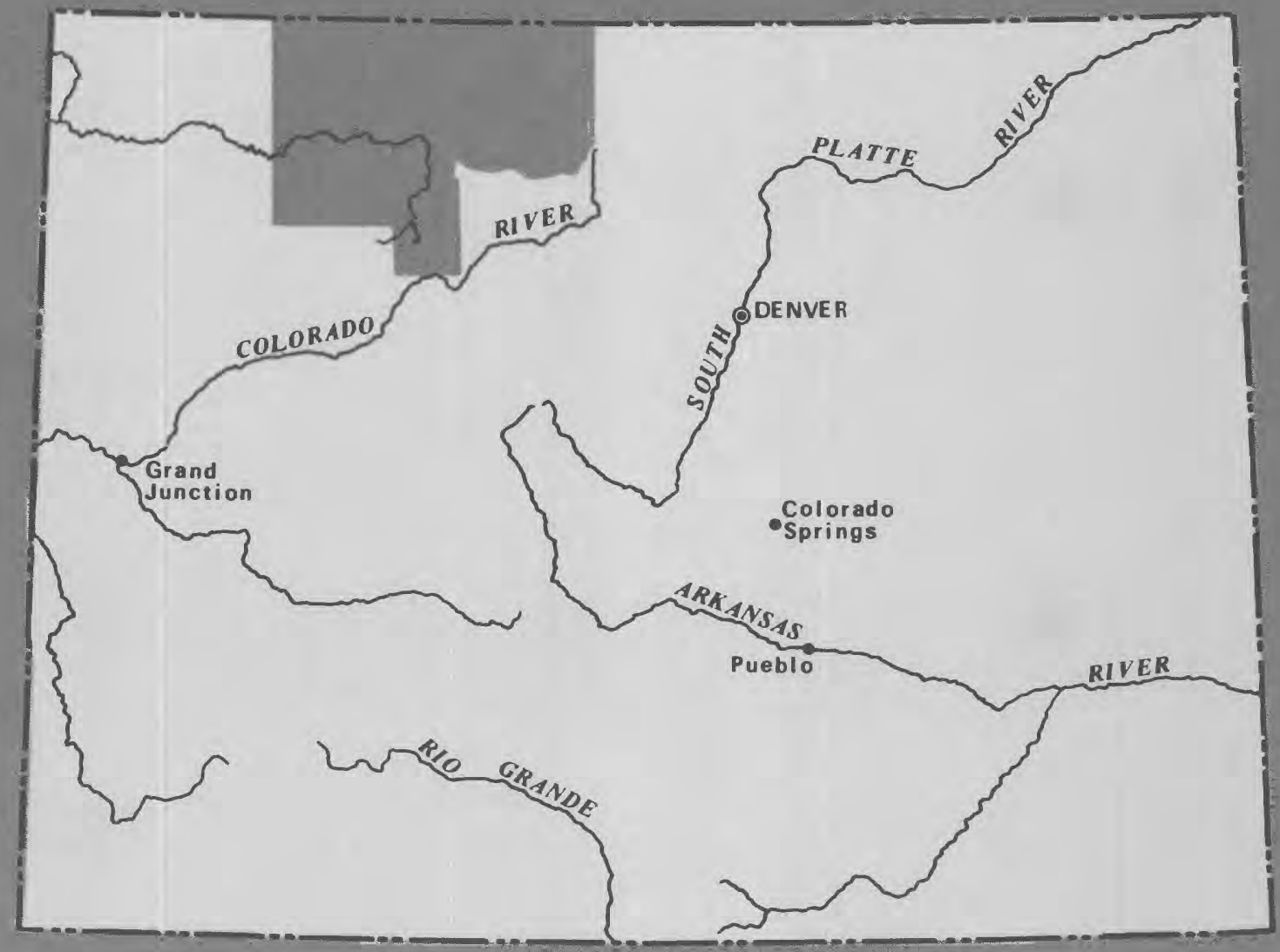

Water-Resources Investigations Report 83-4191 
RECONNAISSANCE OF BENTHIC INVERTEBRATES FROM TRIBUTARY STREAMS OF

THE YAMPA AND NORTH PLATTE RIVER BASINS, NORTHWESTERN COLORADO

By Linda J. Britton

U.S. GEOLOGICAL SURVEY

WATER RESOURCES INVESTIGATIONS REPORT 83-4191

Lakewood, Colorado 1983 


\section{UNITED STATES DEPARTMENT OF THE INTERIOR \\ WILLIAM P. CLARK, Secretary \\ GEOLOGICAL SURVEY \\ Dallas L. Peck, Director}

For additional Information write to:

Colorado District Chief U.S. Geological Survey, MS 415 Box 25046, Denver Federal Center Lakewood, CO 80225
For sale by:

Open-File Services Section Western Distribution Branch U.S. Geological Survey, MS 306 Box 25425, Denver Federal Center Denver, CO 80225 (303) 236-7476 


\section{CONTENTS}

Page

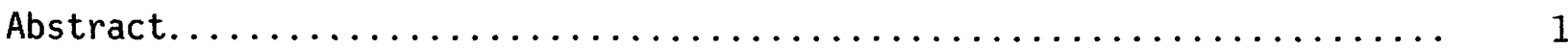

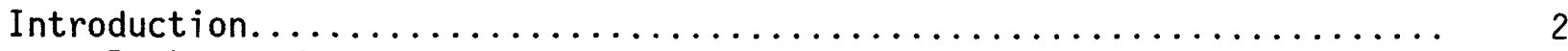

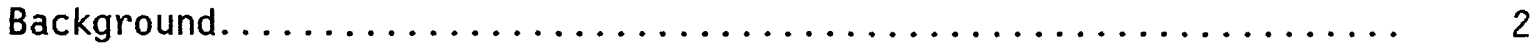

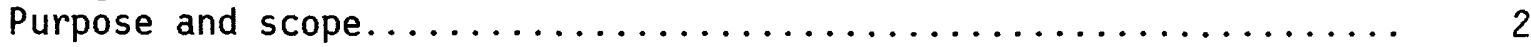

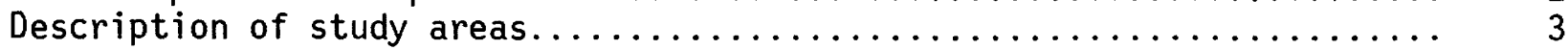

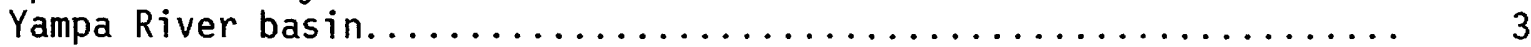

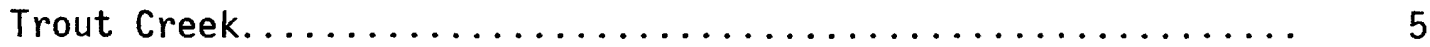

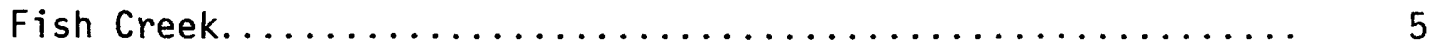

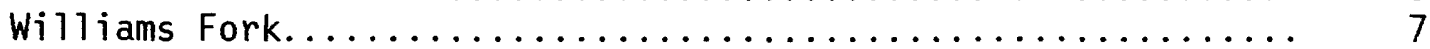

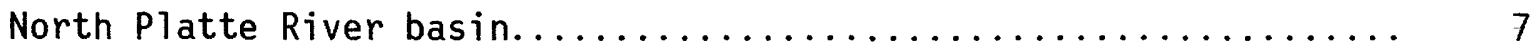

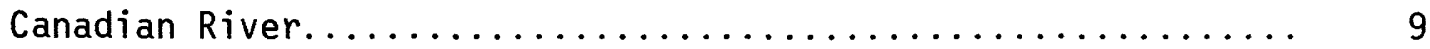

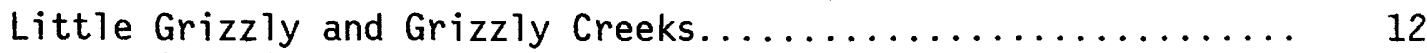

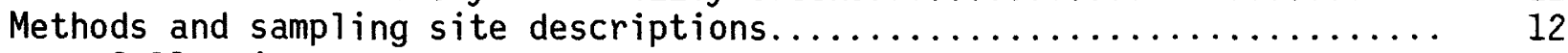

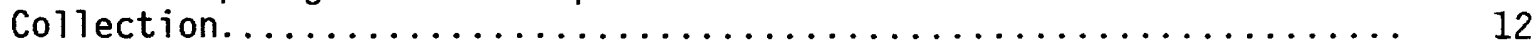

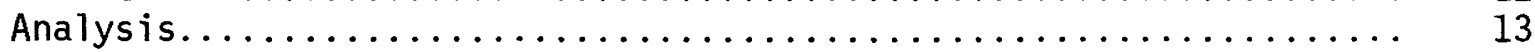

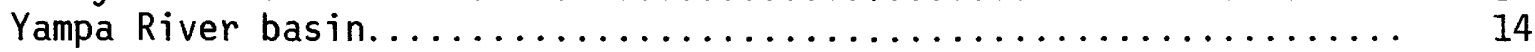

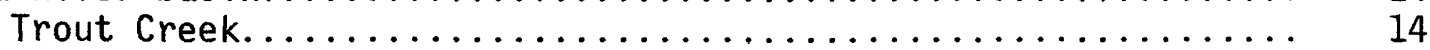

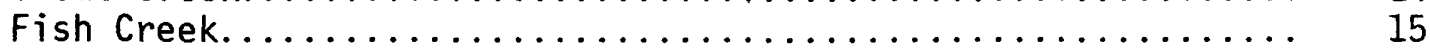

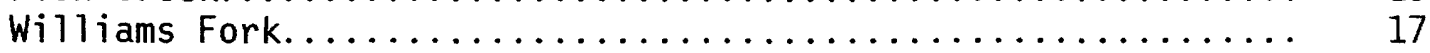

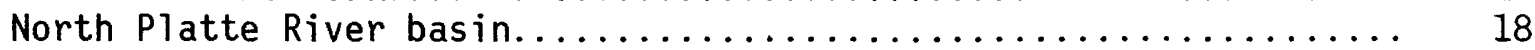

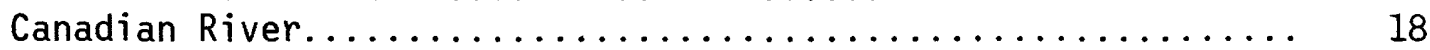

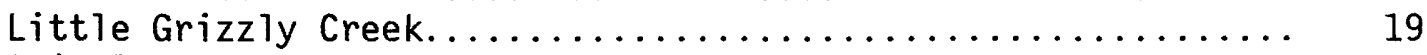

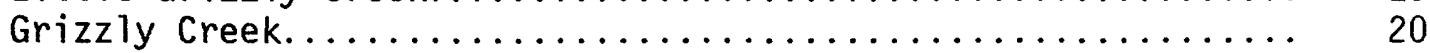

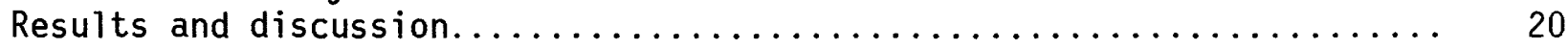

Some general concepts of biological analyses.............. 21

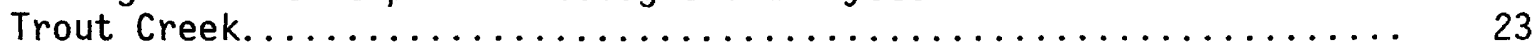

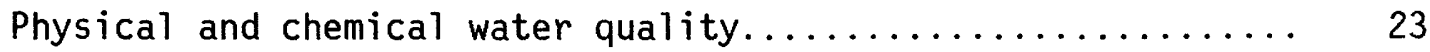

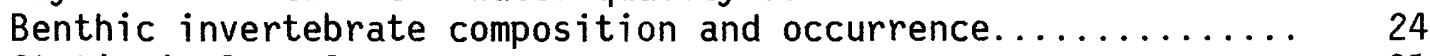

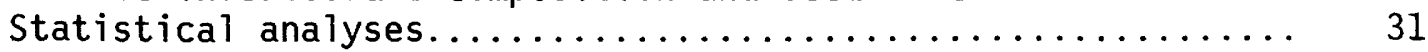

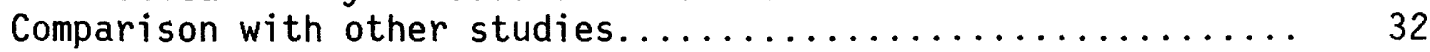

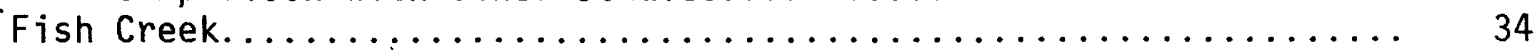

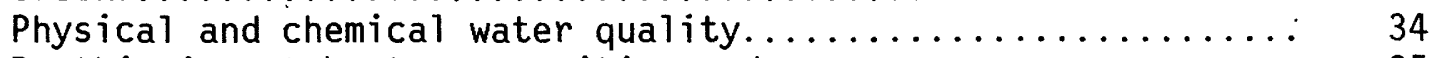

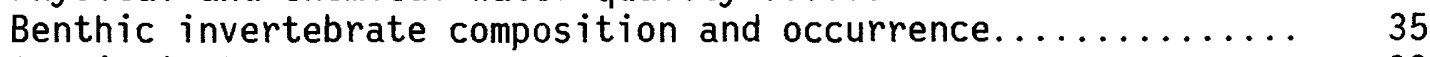

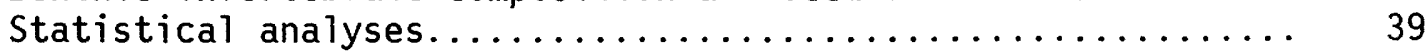

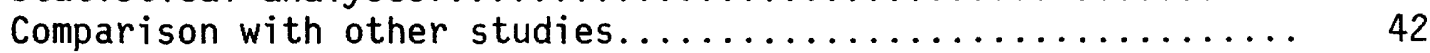

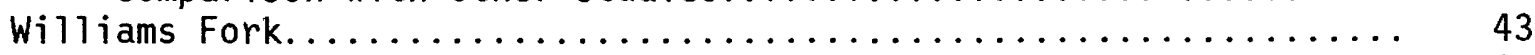

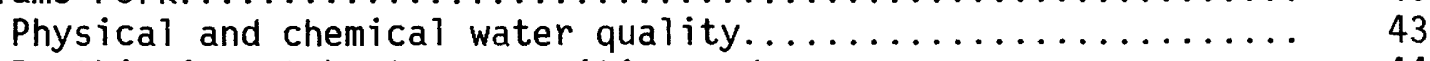

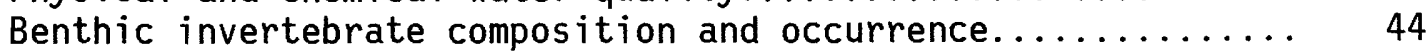

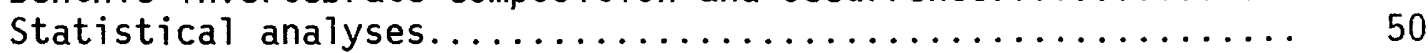

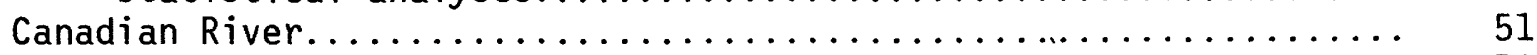

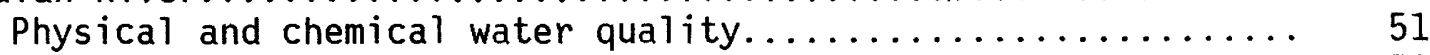

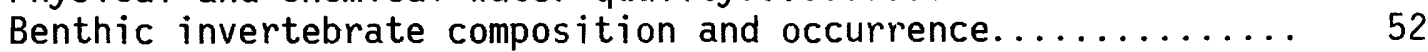

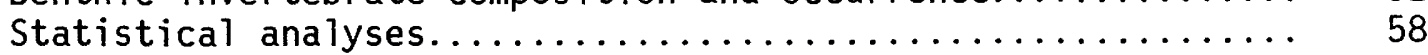

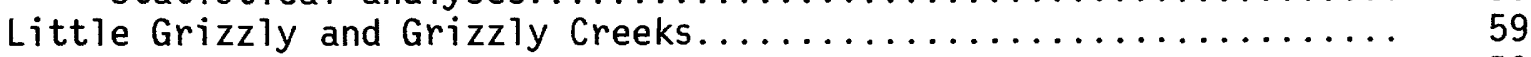

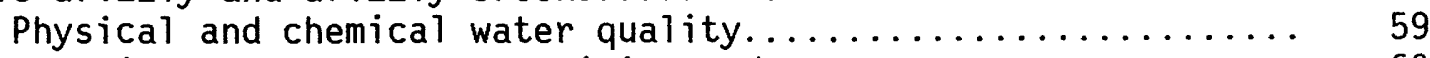

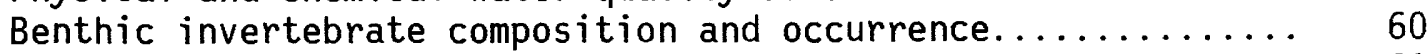

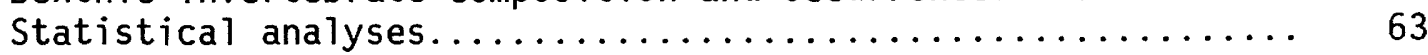


Summary and future monitoring needs $\ldots \ldots \ldots \ldots \ldots \ldots \ldots \ldots \ldots \ldots \ldots$

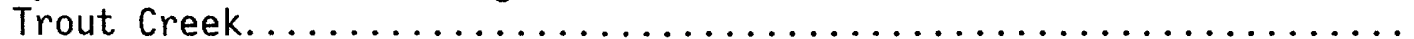

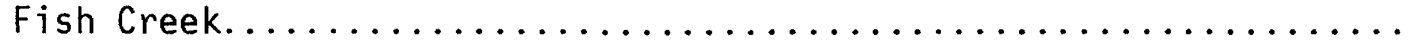

Williams Fork........................................ 69

Canadian River................................... 70

Little Grizzly and Grizzly Creeks....................... 70

References cited................................... 71

ILLUSTRATIONS

Figures 1-5. Maps showing location of:

1. Study area............................. 4

2. Trout Creek, Fish Creek, and sampling sites.......... 6

3. Williams Fork and sampling sites............... 8

4. Canadian River, sampling sites and streamflow-gaging

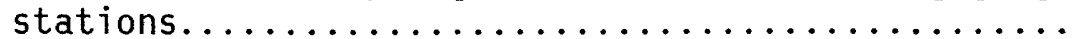

5. Little Grizzly and Grizzly Creeks, sampling sites and streamflow-gaging stations.

6. Diagram showing mean percentage composition of major benthic invertebrate taxonomic groups collected from sites on Trout Creek for all sampling dates............

7. Graph showing percentage composition of major benthic invertebrate taxonomic groups collected from sites on Trout Creek.

8. Graph showing density of benthic invertebrates and taxa, per square meter, collected from sites on Trout Creek...

9. Diagram showing mean percentage composition of major benthic invertebrate taxonomic groups collected from sites on Fish Creek for all sampling dates.............

10. Graph showing percentage composition of major benthic invertebrate taxonomic groups collected from sites on

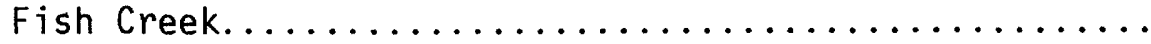

11. Graph showing density of benthic invertebrates and taxa, per square meter, collected from sites on Fish Creek....

12. Diagram showing mean percentage composition of major benthic invertebrate taxonomic groups collected from sites on the Williams Fork for all sampling dates.......

13. Graph showing percentage composition of major benthic invertebrate taxonomic groups collected from sites on

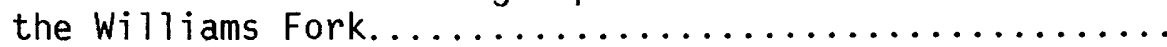

14. Graph showing density of benthic invertebrates and taxa, per square meter, collected from sites on the Williams

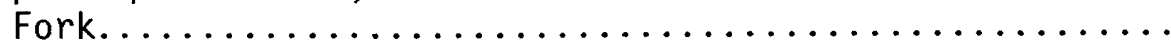




\section{ILLUSTRATIONS}

Figure 15. Diagram showing mean percentage composition of major benthic invertebrate taxonomic groups collected from sites on the

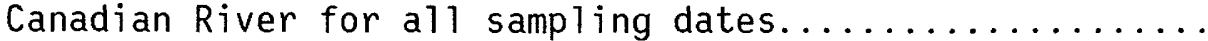

16. Graph showing percentage composition of major benthic invertebrate taxonomic groups collected from sites on the

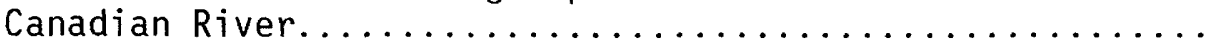

17. Graph showing density of benthic invertebrates and taxa, per square meter, collected from sites on the Canadian River..

18. Diagram showing mean percentage composition of major benthic invertebrate taxonomic groups collected from sites on

Little Grizzly and Grizzly Creeks for all sampling dates..

19. Graph showing percentage composition of major benthic invertebrate taxonomic groups collected from sites on

Little Grizzly and Grizzly Creeks...................

20. Graph showing density of benthic invertebrates and taxa, per square meter, collected from sites on Little Grizzly and

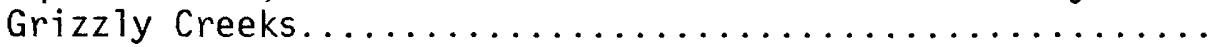

TABLES

Tables 1-5. Mean percentage of size-graded bed-material samples collected from sites on:

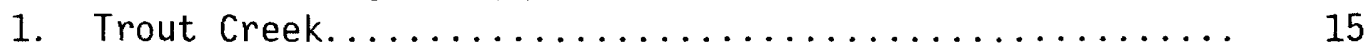

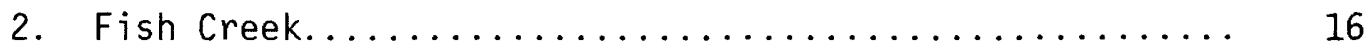

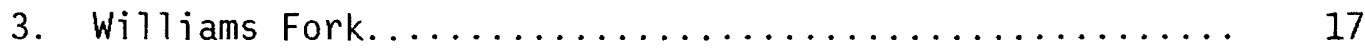

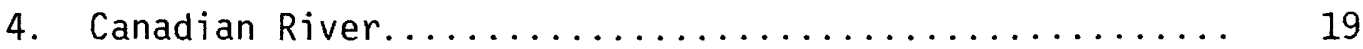

5. Little Grizzly and Grizzly Creeks................ 20

6. Summary of water-quality constituents and properties measured from sites on Trout creek............... 24

7. Relative abundance of benthic invertebrate functional groups collected from sites on Trout creek.......... 26

8. Similarity indices for benthic invertebrates collected from sites on Trout creek.................... 27

9. Species diversity indices for benthic invertebrates collected from sites on Trout creek................ 29

10. Summary of water-quality constituents and properties measured from sites on Fish creek............... 34

11. Relative abundance of benthic invertebrate functional groups collected from sites on Fish creek........... 37

12. Similarity indices for benthic invertebrates collected from sites on Fish creek.................... 37

13. Species diversity indices for benthic invertebrates

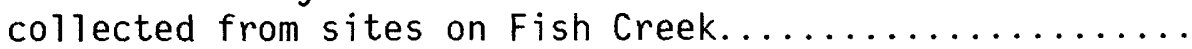


Table 14. Summary of water-quality constituents and properties measured

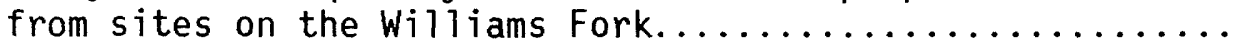

15. Relative abundance of benthic invertebrate functional groups collected from sites on the Williams Fork................

16. Similarity indices for benthic invertebrates collected from

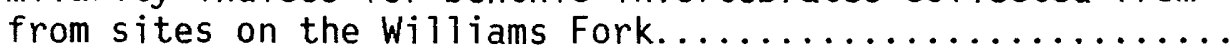

17. Species diversity indices for benthic invertebrates collected

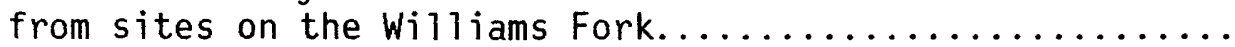

18. Summary of water-quality constituents and properties measured from sites on the Canadian River......................

19. Relative abundance of benthic invertebrate functional groups

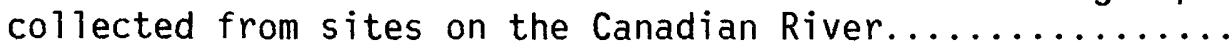

20. Similarity indices for benthic invertebrates collected from sites on the Canadian River...........................

21. Species diversity indices for benthic invertebrates collected

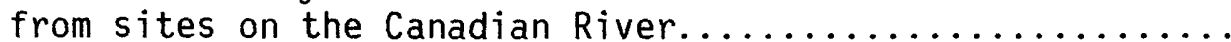

22. Summary of water-quality constituents and properties measured from sites on Little Grizzly and Grizzly Creeks...........

23. Relative abundance of benthic invertebrate functional groups collected from sites on Little Grizzly and Grizzly Creeks..

24. Similarity indices for benthic invertebrates collected from sites on Little Grizzly and Grizzly Creeks...............

25. Species diversity indices for benthic invertebrates collected from sites on Little Grizzly and Grizzly Creeks...........

METRIC CONVERSIONS

Multiply inch-pound unit

foot $(f t)$

inch (in.)

cubic foot per second $\left(\mathrm{ft}^{3} / \mathrm{s}\right)$

mile (mi)

square mile $\left(\mathrm{mi}^{2}\right)$

square foot $\left(\mathrm{ft}^{2}\right)$

ton (short)
$B y$

To obtain metric unit
0.3048
25.40
0.02832
1.609
2.590
0.09290
0.9072

meter

millimeter

cubic meter per second

kilometer

square kilometer

square meter

metric ton

National Geodetic Vertical Datum of 1929 (NGVD of 1929): A geodetic datum derived from a general adjustment of the first-order level nets of both the United States and Canada, formerly called mean sea level. NGVD of 1929 is referred to as sea level in this report. 
RECONNAISSANCE OF BENTHIC INVERTEBRATES FROM TRIBUTARY STREAMS

OF THE YAMPA AND NORTH PLATTE RIVER BASINS, NORTHWESTERN COLORADO

By Linda J. Britton

ABSTRACT

Benthic invertebrates were collected from Trout Creek, Fish Creek, and the Williams Fork (tributaries of the Yampa River in Routt and Moffat Counties), and from the Canadian River, Little Grizzly and Grizzly Creeks (tributaries of the North Platte River in Jackson County). The purpose of the study was to describe and quantify the benthic invertebrate communities in selected streams in coal mining areas. Field water-quality measurements, including water temperature, specific conductance, $\mathrm{pH}$, dissolved oxygen, and bed material size, also were made to aid in assessing the relationship of stream water-quality conditions to benthic invertebrate communities.

Stream sampling sites were located upstream and downstream from potential, existing, or historical coal mining areas. Sampling was conducted on a near bimonthly basis throughout the growing season. Sampling began in April and May 1980 and continued through September 1981.

Density of organisms generally increased downstream in all streams sampled. In Trout Creek there were statistically significant greater densities at a site $(\mathrm{Tr}-3)$ downstream from the Edna Mine, as compared to sites $(\mathrm{Tr}-1, \mathrm{Tr}-2)$ upstream. There was a shift from a we11-balanced community comprised of several functional groups upstream to a community comprised largely of chironomids (collector-type organisms) downstream. In addition, specific conductance increased markedly downstream, probably because of agricultural effects. In Fish Creek there were no significant differences in organism density among the three sites sampled, but there were significantly fewer taxa at the downstream site $(\mathrm{F}-3)$ as compared to upstream. There was very little variation in densities or taxa among the Williams Fork sites. The river has a healthy biotic community with a balanced taxonomic composition, and no particular group dominates. The Williams Fork Strip Mine No. 1 had no discernible effect on the stream biota.

There were no statistically significant differences in densities collected between the two Canadian River sites. The taxa were more diversified at the upstream site $(C R-1)$ than at the downstream site (CR-2), which was also reflected in the diversity index. Diptera comprised mainly of chironimids were much more abundant downstream where they dominated the composition on more than 50 percent of the sampling dates. Composition of the major benthic invertebrate taxa varied slightly between the Little Grizzly Creek sites but was markedly different (because of increased percentage of Diptera) at the Grizzly Creek site. Statistically, mean benthic invertebrate densities were significantly lower at the Grizzly Creek site compared to the two Little Grizzly Creek sites, while mean number of taxa was significantly lower at the Grizzly Creek site. 
Most of the variation in benthic invertebrate densities and taxa among the stream sites was associated with sampling date differences. There were also some strong correlations of mean densities with measured water-quality constituents and properties.

\section{INTRODUCTION}

\section{Background}

As a result of increasing worldwide energy requirements, efforts have been expanded to explore potential energy sources. Development of these sources in Colorado is primarily related to coal extraction and oil shale development. Such activities associated with energy resource development can have a profound effect on local water quality of streams and springs. In general, the potential water-related problems associated with development are: (1) excessive use of available surface waters; (2) increases in dissolved solids and sediment loads in surface waters; and (3) changes in stream morphometry. As a result of these environmental changes, benthic invertebrate communities, as well as other aquatic communities, may be altered. Stream insects may provide a means for detecting gradual changes in the aquatic environment because some species are highly sensitive to pollution. Different types of aquatic insects have become specialized in order to live in particular habitats, and their distribution and abundance can be related to habitat condition.

Specifically, benthic invertebrates have been used as indicators of pollution because (1) they have relatively long life cycles, which cause them to reflect temporary stresses which are difficult to detect by periodic chemical sampling; (2) they are relatively immobile, which keeps them from leaving an area of pollution; and (3) individual groups show different ranges of tolerance to a variety of pollutants (Goodnight, 1973). In earlier studies, benthic invertebrates were sampled and classified using one species as an indicator of pollution. More recently the approach has been to consider the entire fauna at the community level, as well as the stream morphometry, as a measure of water quality.

Benthic invertebrates were sampled in two drainage basins of Colorado where coal is presently or has been previously mined: the Yampa River basin including Trout Creek, Fish Creek, and the Williams Fork; and the North Platte River basin, including the Canadian River, Little Grizzly Creek, and Grizzly Creek.

\section{Purpose and Scope}

The study was designed to describe and quantify the benthic invertebrate communities in selected streams in coal mining areas. A secondary purpose was to compare the results with other data collected prior to this study and to assess possible changes in water quality reflected in the composition of the benthic invertebrate community. 
Generally, sampling provided quantitative and qualitative data on density and on relative abundance of various benthic invertebrate species. In addition, field water-quality constituents and properties, consisting of temperature, specific conductance, $\mathrm{pH}$, and dissolved oxygen, were measured. Bed material was collected for particle-size analyses at selected sampling intervals. The basic data collected in this study is in the report by Britton (1983).

Sampling began in April and May 1980, continued on a nearly bimonthly basis during the growing (open water) season (April-November), and was completed in September 1981. Because of streamflow conditions and the timing of periods of maximum productivity, data were collected mainly after ice had melted in late spring and during the low-flow periods of summer and early autumn.

\section{DESCRIPTION OF STUDY AREAS}

\section{Yampa River Basin}

The Yampa River basin is in northwestern Colorado (fig. 1) and south-central Wyoming (not in study area). The basin occupies an area of approximately 8,080 square miles. Although the basin is in parts of seven counties, the study area reported here includes only parts of two counties: Routt and Moffat. However, the combined basin areas in these counties constitute about two-thirds of the total drainage area. In addition, the majority of the population and economic activity within the basin occurs in these two counties.

Population declines between 1930 and 1960 have been negated by population increases in the 1970's because of increased recreational development and extensive coal mining and powerplant construction, especially in Routt and Moffat Counties. The preliminary 1980 census (U.S. Department of Commerce, 1981, p. 7-4) indicated a population of 13,374 (compared with 6,592 in 1970) for Routt County, and a population of 13,129 (compared with 6,525 in 1970) for Moffat County. Within these counties, 61 percent and 93 percent of the population are in the Steamboat Springs and Craig divisions. Projected population increases for 1990 (Colorado Division of Planning, 1979) are 31 to 55 percent in Moffat County and 48 to 63 percent in Routt County. These increases are expected as a result of energy resource development.

The major energy resource in the Yampa River basin is the near-surface coal deposits (Steele and others, 1979). Other available energy resources are oil and gas, oil shale, uranium, and geothermal springs. The direct and indirect effects from increasing development may cause environmental stresses, including changes in land and water use, and possibly increased levels of domestic and industrial waste-water discharges. Given the limited availability of water in the region, increasing competition is expected among mining-related, agricultural, and municipal-industrial uses (Steele and others, 1979). 


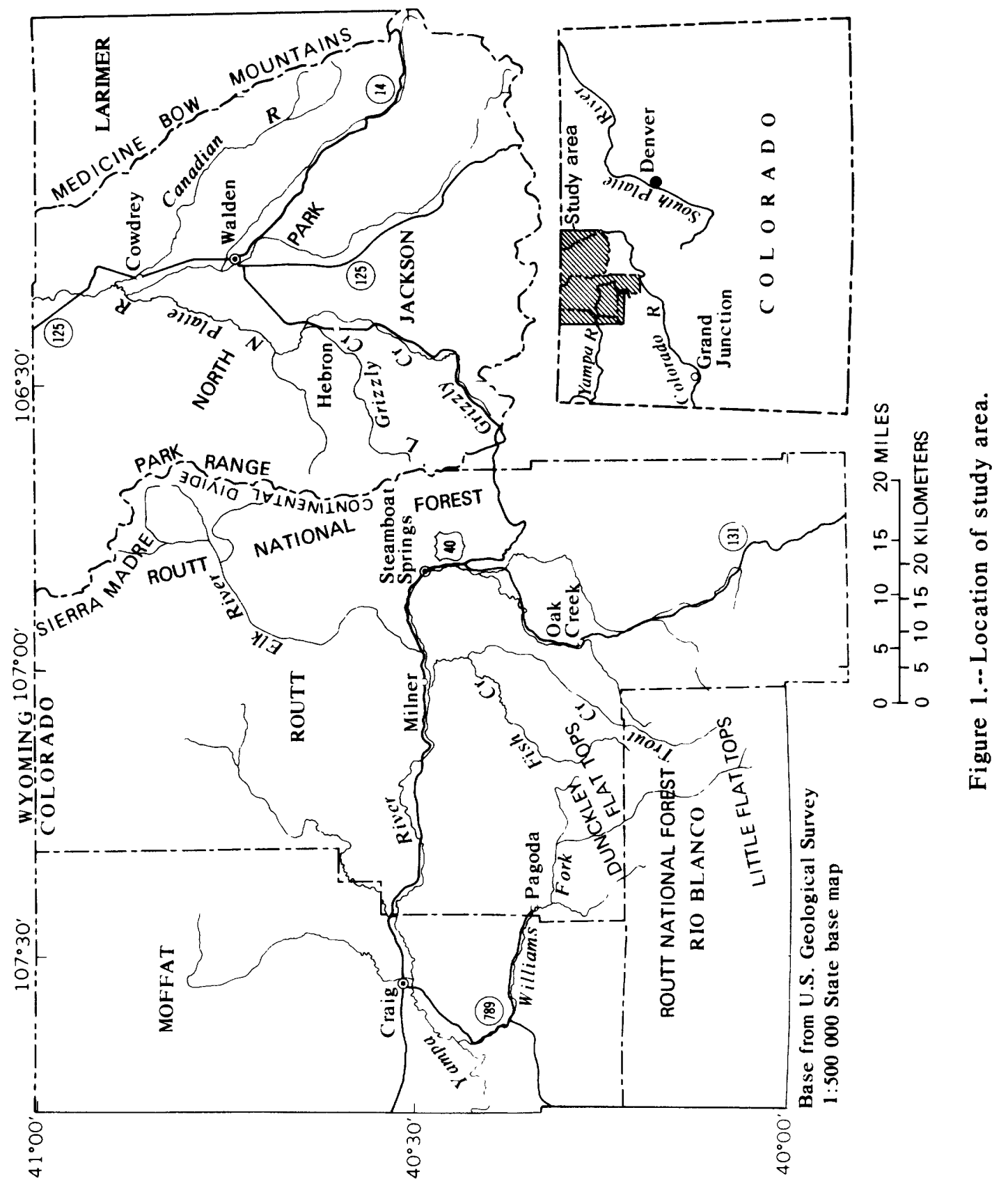


Principal economic activities in the basin are agriculture (dryland farming, livestock production, irrigated crops); recreation; coal, oil-shale, and uranium mining; oil and gas extraction; and miscellaneous municipal and rural services.

\section{Trout Creek}

Trout Creek is a moderate-sized stream which flows in a northerly direction through the northeast part of Rio Blanco County and the southeast and central parts of Routt County (fig. 1). The stream originates in the Little Flat Tops (fig. 1) in the Routt National Forest and flows north to its confluence with the Yampa River south of Milner (fig. 2). Altitude of land surface ranges from near 12,000 feet in the upper part of the basin to 6,500 feet near the confluence. The amount of precipitation decreases as altitude decreases, which affects vegetation patterns. The upper part of the basin is heavily vegetated with aspens, willows, conifers, and native grasses. Stands of willows provide shaded pools, overhanging cover, and stable undercut banks, all of which provide good fish habitat. Vegetation in the lower part of the basin is sparse and consists of sagebrush, woody shrubs, and grasses. The middle and lower reaches are a mixture of forested, farmed, and surface-mined lands. Irrigated hay meadows and grazing lands are more extensive in these reaches than upstream.

The Pittsburg and Midway Coal Mining Co. has been operating a strip-coal mine (Edna Mine) in the basin for more than 40 years. The coal spoils at the mine are regraded and vegetated, and settling ponds have been constructed for all point source discharges. The mine produced about 1.1 million tons during 1980 and about 1 million tons during 1981 (Pittsburg and Midway Coal Mining Co., oral commun., 1982).

Upstream of the Edna Mine, Sunland Mining Corp. operates a coal mine about 5 miles west of Oak Creek (fig. 2). In 1980, the mine produced about 4,000 tons of coal, and in 1981 it produced about 10,000 tons (Sunland Mining Corp., oral commun., 1982). A settling pond prevents direct discharge to Trout Creek.

\section{Fish Creek}

Fish Creek, a tributary to Trout Creek, originates in the Dunckley Flat Tops (fig. 1) at an altitude near 10,000 feet. The creek flows in a northeasterly direction to its confluence with Trout Creek at an altitude of 6,700 feet, approximately 5 miles southeast of Milner, Colo. (fig. 2). Fish Creek drains 77.5 square miles and has an average gradient of 0.2 percent. Basin vegetation consists of sagebrush, oak brush, rabbit brush, and various types of native grasses; woody riparian vegetation is sparse, providing little cover. The lands are used for range and wildlife grazing. 


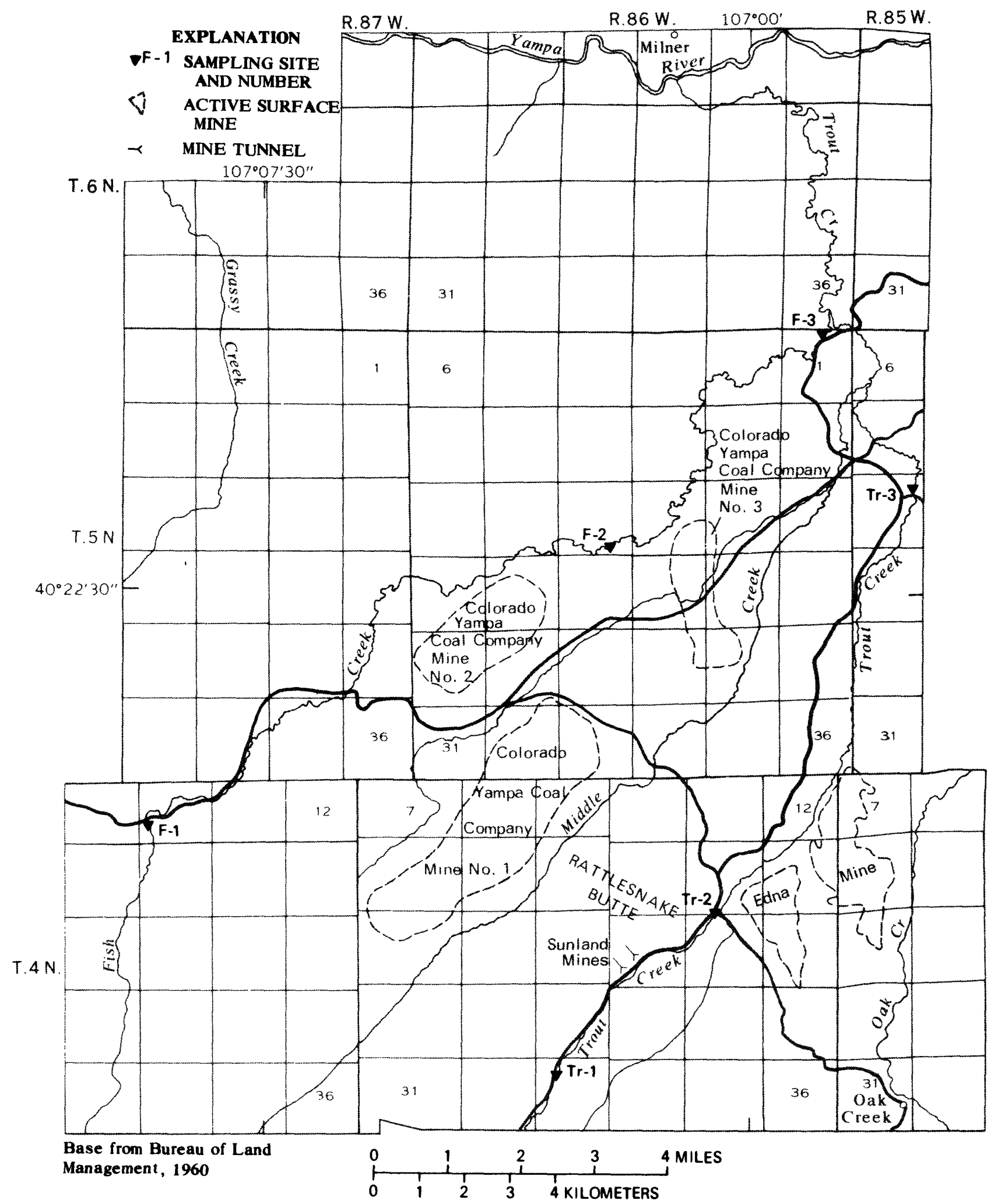

Figure 2.-- Location of Trout Creek, Fish Creek, and sampling sites. 
Parts of the creek flow along the northwest sides of three surface coal mines, that are now operated by the Colorado Yampa Coal Co., a subsidiary of Getty 0 il Co. In 1980, the surface mines (mines 1, 2, and 3) produced a combined total of about 3.6 million tons of coal (Colorado Yampa Coal Co., oral commun., 1981). In 1981 only one surface mine was in operation, and through October 1981 it produced about 2.9 million tons of coal.

\section{Williams Fork}

The Williams Fork, the principal southern tributary of the Yampa River, rises from two forks at altitudes near 10,000 feet. After the forks join near Pagoda, the river flows northwesterly along the south side of the Williams Fork Mountains to its confluence with the Yampa River about 5 miles northwest of Hamilton (fig. 3).

Upper parts of the Williams Fork basin are heavily forested, but the river in the study area flows through an alluvial valley covered with native grasses and aspens, and land use is primarily for livestock grazing and hay production. Water from the river is used primarily for irrigation and for livestock watering. Near the confluence with the Yampa River, the Williams Fork flows alongside a coal mine (Williams Fork Strip No. 1), operated by Empire Energy Corp. In 1980 the No. 1 mine produced about 3.3 million tons of coal, and in 1981 the mine produced about 3.4 million tons of coal (Empire Energy Corp., oral commun., 1982).

\section{North Platte River Basin}

The North Platte River basin is in the north central part of Colorado (fig. 1), and has a drainage area of about 2,030 square miles. Most of the population and economic activity are centered near Walden, the Jackson County seat. The 1980 census (U.S. Department of Commerce, 1981, p. 7-3) indicated a population of 1,865 in Jackson County, with 950 residents in Walden. The population is projected (Colorado Division of Planning, 1979) to increase as much as 50 percent by 1990 . Coal resource development and recreation, including a proposed ski area, are expected to provide the greatest potential for growth.

Most prominent of the wide variety of topographical features in the basin is an open plateau known as North Park. The Park is bordered on the east by the Medicine Bow Mountains, on the west by the Sierra Madre and Park Ranges, and is drained by an extensive network of streams. A major part of the bottom land along streams in North Park is irrigated hay meadows and pastures. Sagebrush and dry grassland lie between the water courses and the forested mountainsides. The mountain slopes are covered with aspen, spruce, pine, and fir up to timberline at an altitude of about 11,000 feet. Above timberline, tundra and rock extend up to the mountain summits. 


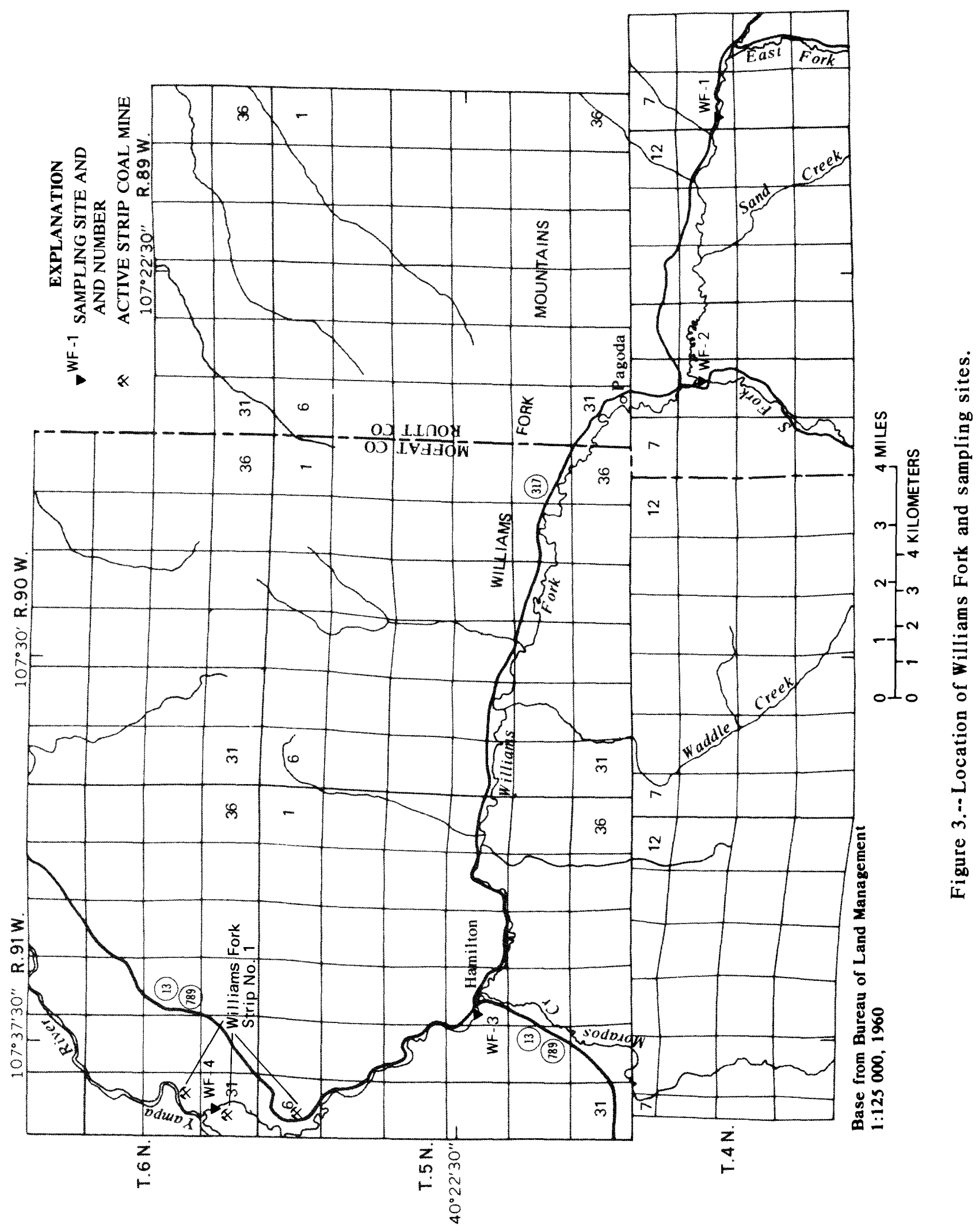


About 50 percent of the total land area is in Federal ownership, 12 percent in State ownership, and the remaining 38 percent in private ownership. The major economic base is ranching and irrigated croplands; 12 percent of Jackson County's 1,628 square miles is irrigated hay and pasture land. Ranching is predominant not only on privately-owned land but also on U.S. Bureau of Land Management and U.S. Forest Service lands. Secondary land uses include mining and logging.

Coal mining has taken place in Jackson County sporadically since about 1885. Mining ceased in 1960 and was resumed in 1974. In 1975, three coal mines were in operation: two in the McCallum District east of Walden (fig. 4), and one in the Coalmont Mining area south of Hebron (fig. 5). Three strip mines presently (1982) operate, but only in the area east of Walden. The largest is the Kerr Coal Company Mine, operated by Energy Fuels Corporation, which produced about 723,000 tons in 1980 (Energy Fuels Corp., oral commun., 1982), about a threefold increase since production started in 1975. However, production decreased during the period of January through September 1981 to about 258,000 tons. Two other mines operate on a smaller scale: Walden Coal Co. Mine, which broke ground in 1979 and produced about 120,000 tons during its first year, and the Canadian Strip Mine operated by Wyoming Fuels Corp., which produced about 85,000 tons in 1981 (Colorado Division of Mines, oral commun., 1982). Plans for a new lease indicate a continuing production of about 300,000 tons per year.

According to Gerhard Kuhn and R. S. Williams, Jr. (U.S. Geological Survey, written commun., 1982), streamflow in North Park can be described as follows: Phase 1 begins in early spring when ice breakup and snowmelt at low elevations cause sharp increases in stream discharge. Streamflow during this phase is a variable mix of ground-water discharge and snowmelt runoff. Phase 2 begins in late June, when snowmelt subsides. In July and August, rainstorms cause moderate increases in streamflow. In September, baseflow conditions become established and prevail throughout winter except for minor fluctuations caused by precipitation and temperature. Baseflow is sustained primarily by ground-water discharge to streams from the alluvial aquifer adjoining the river channel.

\section{Canadian River}

The Canadian River rises from two forks on the west side of the Medicine Bow Mountains at an altitude of about 11,000 feet (fig. 1). The river flows northwesterly to its confluence with the North Platte River near Cowdrey, at an altitude of about 8,000 feet. Upper parts of the river lie in a heavily forested area, but downstream the river enters a relatively broad valley of brush and native grassland. In the valley, the river meanders for about 40 miles descending only about 200 feet. During higher flows, the river comprises relatively deep, slow-moving pools, but lower flows expose sandbars and large riffle areas. Most of the river is completely open, and little shade is provided by scant vegetative cover. 


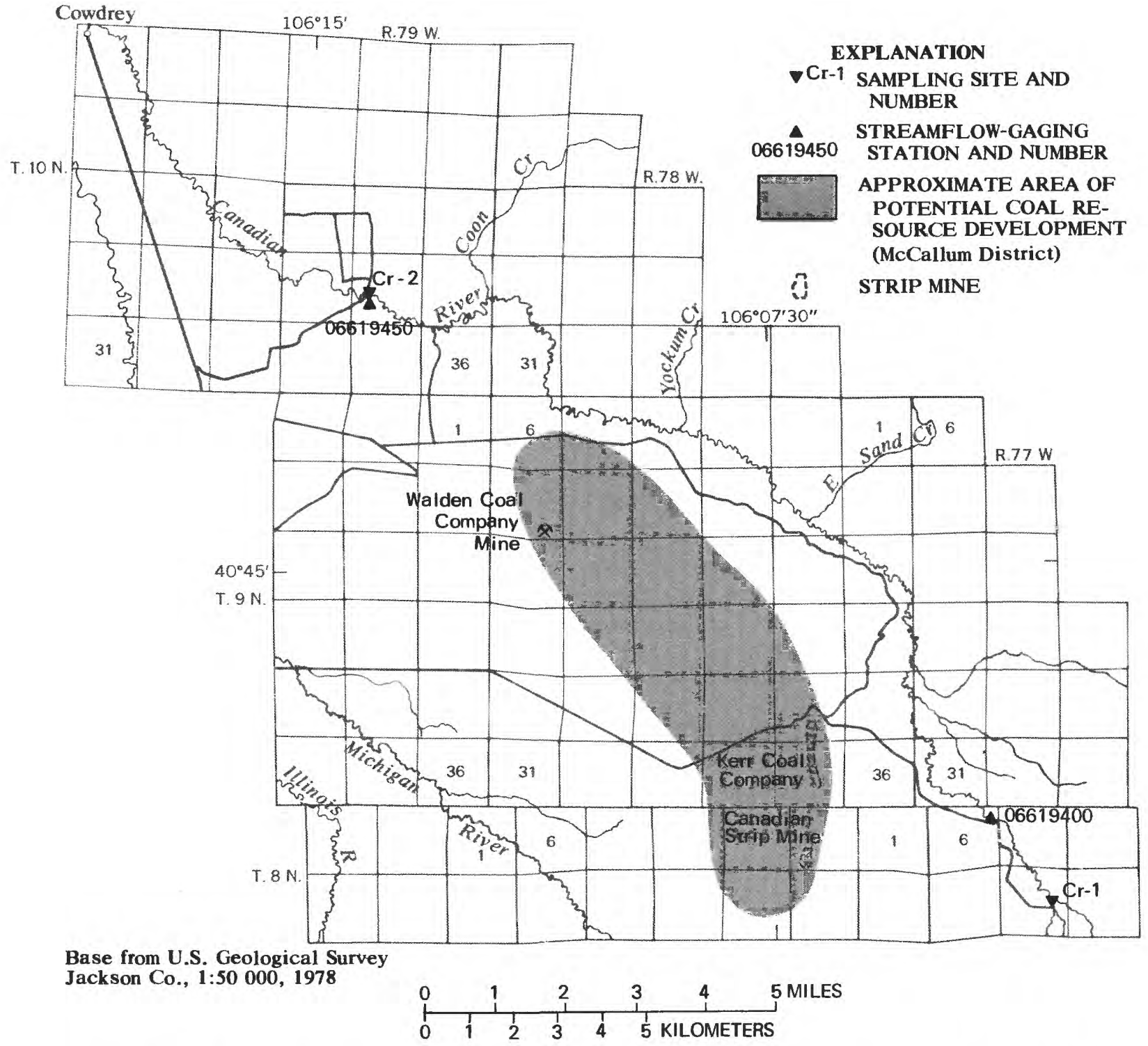

Figure 4.-- Location of Canadian River, sampling sites and streamflow-gaging stations. 


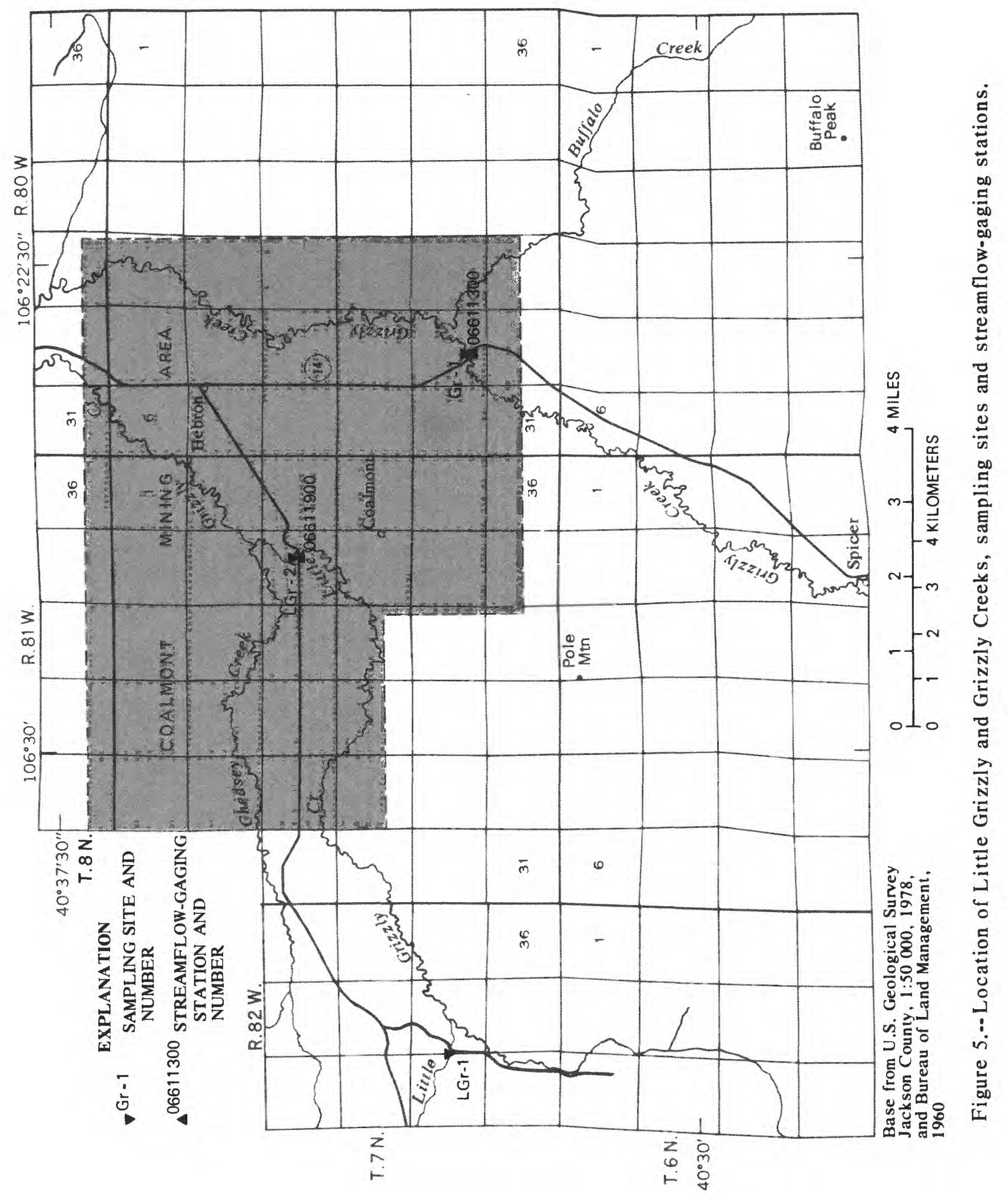


Land in the basin is used almost entirely for ranching which includes grazing and irrigated crop production. During the growing season of May through August, a considerable demand is placed on Canadian River water for flood-type irrigation of hay meadows within and adjacent to its flood plains. These diversions, together with the associated return flows, greatly affect the natural flow of the river and its tributaries. In addition to ranching, there are coal mines, several oil and gas wells, and a fluorspar mine operating in the Canadian River basin.

\section{Little Grizzly and Grizzly Creeks}

Little Grizzly and Grizzly Creeks originate from the west-central and southwest parts of the Park Range near the Continental Divide at altitudes of about 10,000 feet and 9,000 feet (fig. 1). The creeks flow out of the heavily forested mountains into the western parts of North Park's valley bottom. Like the Canadian River, Little Grizzly and Grizzly Creeks flow through ranchland consisting of irrigated hay meadows and pasture. The two creeks join about 3 miles north of Hebron, forming the North Platte River (fig. 1).

Within the Grizzly Creek basin lies the Coalmont Mining area (fig. 5), which was a center of coal mining operations from 1909 to 1940, and from which about 1.5 million tons of coal were produced (Erdmann, 1941). For comparison, Jones and Murray (1976) indicated that about 1.1 million tons were extracted between 1909 and 1960. Little mining has taken place recently, but Speltz (1976) estimated that about 123 million tons of strippable coal remain in the area.

\section{METHODS AND SAMPLING SITE DESCRIPTIONS}

Biological and water-quality sampling sites were selected in areas where coal was being mined, or where mining was expected. Control sites were selected upstream from all mining, and at least one site on each stream was located downstream from each mine or potential mining area. Sites also were selected in conjunction with an ongoing study determining traveltime and reaeration rates on the same stream reaches. Whenever possible, biological sampling sites were located at existing U.S. Geological Survey water-quality stations or streamflow gaging stations.

\section{Collection}

Beginning in April 1980, benthic invertebrates were collected at selected sites with a square-foot Surber sampler having a 210- $\mu$ m (micrometer) mesh net, using the methods described by Greeson and others (1977). In most instances, three replicate samples were collected in riffle areas at each site. According to Gaufin and others (1956), three Surber samples will generally contain one-half to two-thirds of the species observed in ten samples. In addition, the separate analysis of each sample indicates differences in distribution of numbers and taxa at a site. 
Field measurements of water temperature, specific conductance, $\mathrm{pH}$, and dissolved oxygen were made with a multiparameter unit. At sites having staff gages, streamflow was determined from a rating curve. Bed-sediment samples were collected in 1980 for particle-size analyses according to procedures in Guy (1969). Results of percentage compositions of bed-material samples for each stream site are given in the following sections. The results are reported as mean percentages for all samples collected at each site.

\section{Analysis}

Benthic invertebrates were identified and counted by a private laboratory. The first set of benthic invertebrate samples (collected April and May 1980) was analyzed by a different laboratory than were the other sets of samples. Although the results from the first set of samples are given in Britton (1983), for consistency purposes they are not included as part of the summaries or calculations of this report. Bed-material samples were analyzed for particle size at the U.S. Geological Survey laboratory in Lakewood, Colo., according to the procedures in Guy (1969). The bed material finer than $320 \mathrm{~mm}$ was sieved into size fractions according to the recommended scale in Guy (1969, table 2). Silt-sized bed material (finer than $0.062 \mathrm{~mm}$ ) was analyzed by the pipet method.

A computer program was used to statistically analyze the biological and water-quality data. The Statistical Analysis System (SAS) was employed to test for differences in the biological data and to measure the strength of relationships between variables (SAS Institute, Inc., 1982). Analys is of variance (ANOVA), t-test, and correlation procedures were used in this study. A11 tests were performed at the 95-percent probability level $(p=0.05)$, and were based on data transformed to the log base 10 .

The analysis of variance is a statistical test whereby the total variation in a set of data is partitioned into components associated with possible sources of variability (Elliott, 1971). A two-way analys is of variance was used to test for significant differences in density of organisms and taxa between and within sites and for effects of different sampling dates. Variation in density from site to site or from date to date is considered the between-group variance. Another part of the total variance is due to natural variations and sampling and analytical error.

The $t$-test is a simple statistical procedure which evaluates the difference bewtween two means. The two means being tested may be a sample and a population mean, or two sample means from two populations. The t-test procedure was used to analyze for significant differences in densities collected in replicate samples at a given site. A t-statistic was computed to determine whether the means of any two groups of data were equal. 
A final procedure used to analyze the biological and water-quality data was the determination of correlation coefficients. Correlation measures the strength of the relationship between two variables. For example, densities of benthic invertebrates were correlated with each of the measured water-quality constituents and properties and a correlation coefficient ( $r$ ) was determined. Coefficients range from -1 to 1 , with 0 indicating no relationship and -1 or 1 indicating a perfect relationship. In addition, a stepwise procedure was used to determine if more than one water-quality constituent or property contributed to the density of benthic invertebrates. The procedure searches for the best model by bringing into the regression equation the independent variables, one by one.

The small sample size at each site (less than 10 samples) may be a factor in the statistical results. Some strong correlations between benthic invertebrate densities and water-quality data were calculated, and these results should be reinvestigated using a larger sample (greater frequency of sampling). The correlations given in this report are intended to show only that benthic invertebrate densities may tend to vary in relationship to the tested water-quality constituents and properties. Thus, they are not shown as cause and effect relationships. In fact, there are many other untested variables that may effect these relationships.

In the following sections, the sampling site descriptions are preceded by a sampling site number, ( $\mathrm{Tr}-1$, for example) that corresponds to the numbers on the location maps (figs. 2-5). Following the sampling site number in parenthesis, is the latitude and longitude.

Yampa River Basin

Trout Creek

$\operatorname{Tr}-1$ (1at $40^{\circ} 16^{\prime} 40^{\prime \prime}$ N., long $107^{\circ} 03^{\prime} 05^{\prime \prime}$ W. )

This upstream sampling site on Trout Creek, at an altitude of about 7,500 feet, is approximately 6 miles west of 0 ak Creek and 2 miles upstream from the Sunland Mines (fig. 2). The bed material is composed of gravel, sand, and silt (table 1). Riparian vegetation is mainly willows, cottonwoods, and grass. The stream site has riffles interspersed with a few deep pools. The site is along a county road, but the stream and surrounding land are private and are used for grazing livestock and hay production.

Tr-2 (lat $40^{\circ} 18^{\prime} 33^{\prime \prime}$ N., long $107^{\circ} 00^{\prime} 34^{\prime \prime}$ W. )

This site on Trout Creek is about 3 miles west of Oak Creek, at an altitude of 7,200 feet. The site is about 2 miles downstream from the Sunland Mines and immediately upstream from the Edna Mine (fig. 2). At this point, the stream leaves a narrow valley and enters a flood plain downstream. The bed material is composed of gravel with sand and silt (table 1). The riparian vegetation consists of willows and grass. 
Table 1.--Mean percentage of size-graded bed-material samples collected from sites on Trout Creek

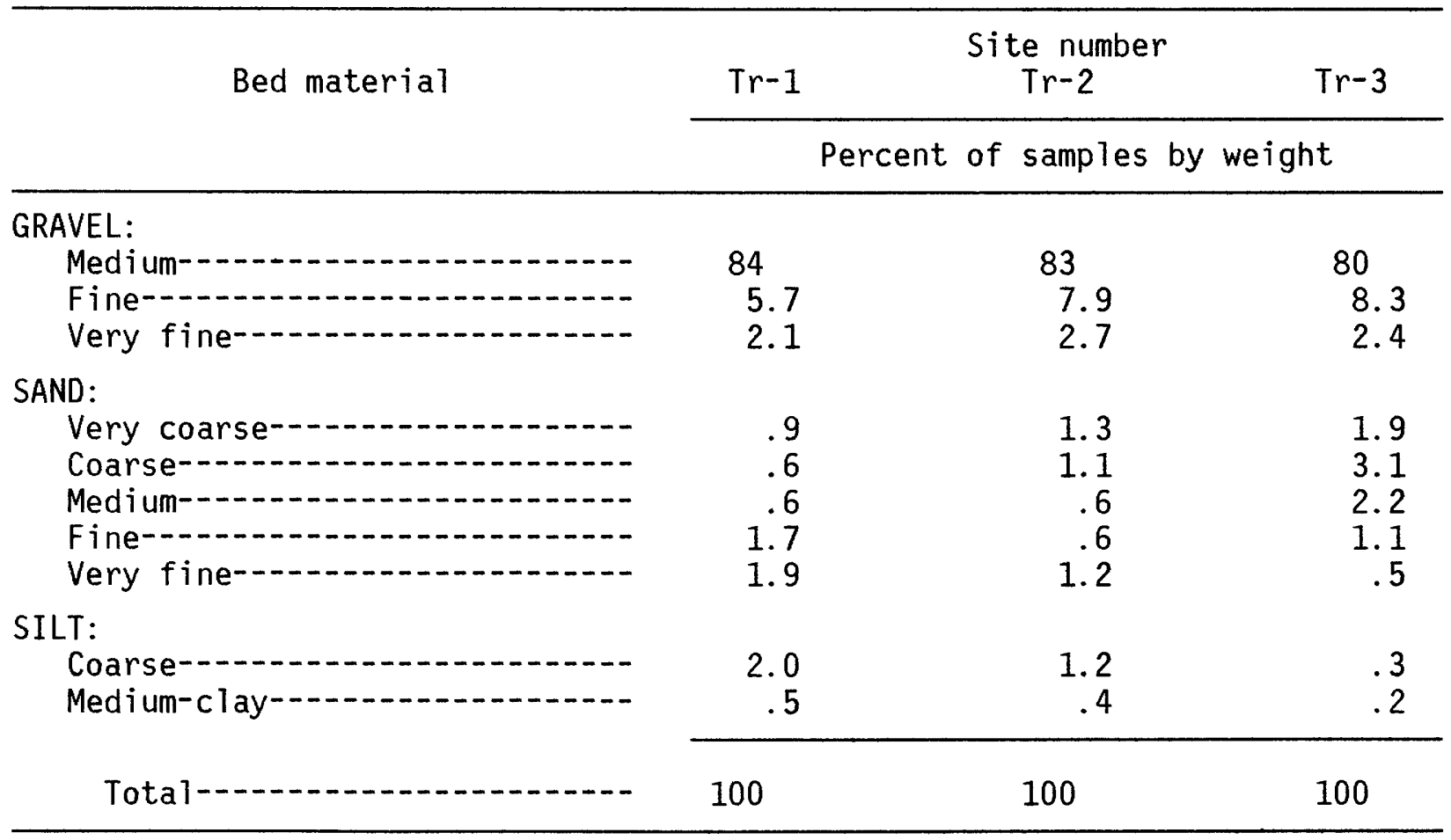

$\operatorname{Tr}-3$ (lat $40^{\circ} 23^{\prime} 38^{\prime \prime}$ N., long $106^{\circ} 57^{\prime} 36^{\prime \prime}$ W.)

This is the downstream sampling site on Trout Creek at an altitude of about 7,000 feet. This site is approximately $12 \mathrm{miles}$ southwest of Steamboat Springs, Colo., (fig. 1) and is downstream from all present mining and related activities (fig. 2). The creek is within a broad valley, and increased grazing has left mainly grasses which provide little shade bordering the stream. The bed material consists of small-size gravel and sand (table 1 ). There is a greater proportion of fine material, especially sand, than at the upstream sites.

\section{Fish Creek}

F-1 (lat $40^{\circ} 20^{\prime} 10^{\prime \prime}$ N., long $107^{\circ} 08^{\prime} 20^{\prime \prime}$ W. )

This upstream sampling site on Fish Creek is at a water-quality monitoring and streamflow-gaging station operated by the U.S. Department of Agriculture-Science and Education Administration (USDA-SEA). The site is 12 miles southwest of Milner and 3.5 miles upstream from Colorado Yampa Coal Co. Mine 2 (fig. 2). The drainage area is 34.3 square miles, and the sampling site is at an altitude of 6,910 feet. The bed material is mainly gravel and sand (table 2). The stream is in an arid, narrow valley characterized by some willows and dry grasses on steeply eroding banks. 
F-2 (lat $40^{\circ} 23^{\prime} 00^{\prime \prime}$ N., long $107^{\circ} 02^{\prime} 27^{\prime \prime}$ W. )

This site on Fish Creek is the middle USDA-SEA sampling station and is about 7 miles south of Milner, at an altitude of about 6,700 feet (fig. 2). The station lies approximately 4 miles north of Colorado Yampa Coal Co. Mine 1 and is immediately downstream from Mine 2. This site drains an area of about 54 square miles. The bed material is mainly medium to fine material consisting of fine gravel, sand, and silt (table 2). The riparian vegetation consists of dry grasses and brush, and the surrounding land is used for grazing and some dryland crop production.

Table 2.--Mean percentage of size-graded bed-material samples collected from sites on Fish Creek

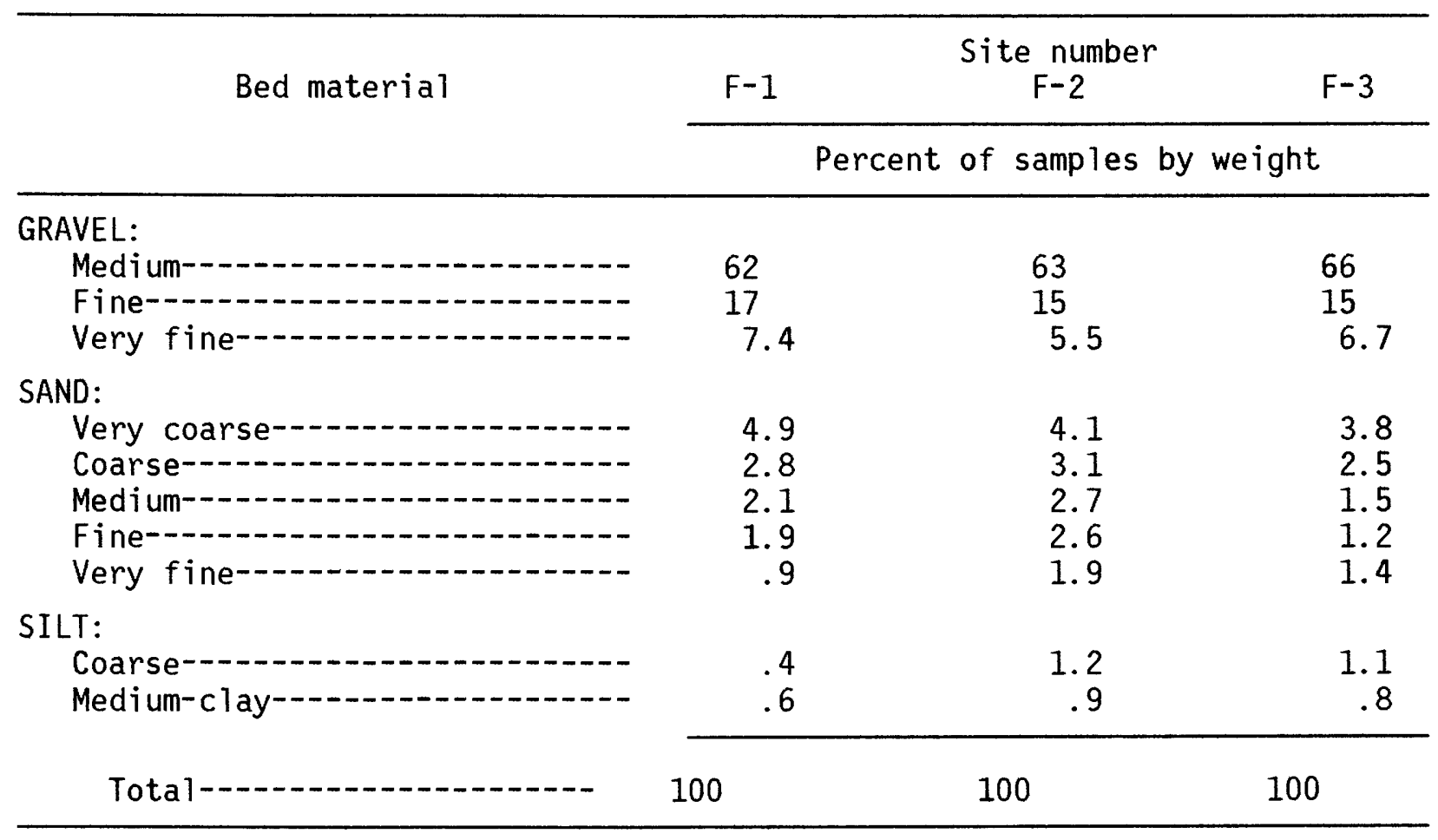

F-3 (lat $40^{\circ} 25^{\prime} 30^{\prime \prime}$ N., long $106^{\circ} 58^{\prime} 57^{\prime \prime}$ W.)

This sampling site on Fish Creek is at the downstream USDA-SEA station, about 5.5 miles southeast of Milner. The site is downstream from Colorado Yampa Coal Co. Mine 2 and parts of Mine 3 (fig. 2). The site receives drainage from 77.5 square miles and is at an altitude of 6,580 feet. The bed material is mainly medium and fine gravel underlain by sand (table 2). The riparian vegetation consists of dry grasses and brush, and surrounding lands are used primarily for livestock and wildlife grazing. 


\section{Williams Fork}

WF-1 (1at $40^{\circ} 18^{\prime} 47^{\prime \prime}$ N., long $107^{\circ} 19^{\prime} 35^{\prime \prime}$ W. )

This is the upstream sampling site on the main stem (East Fork) of the Williams Fork (fig. 3). The site is at an altitude of about 6,800 feet and is about 25 miles west of Oak Creek (fig. 1). The site is at the upstream end of a relatively narrow valley comprised of irrigated meadow and pasture 1 and. The major land use is ranching including livestock and hay production. Water from the Williams Fork is used for stock watering and irrigation. The bed material is composed of large cobbies and small boulders (not in table 3 ), underlain by medium gravel and sand (table 3 ).

Table 3.--Mean percentage of size-graded bed-material samples collected from sites on Williams Fork

\begin{tabular}{|c|c|c|c|c|}
\hline \multirow[t]{2}{*}{ Bed material } & \multicolumn{4}{|c|}{$\begin{array}{c}\text { Site number } \\
W F-2\end{array}$} \\
\hline & \multicolumn{4}{|c|}{ Percent of samples by weight } \\
\hline $\begin{array}{l}\text { GRAVEL: } \\
\text { Medium } \\
\text { Fine } \\
\text { Very fine }\end{array}$ & $\begin{array}{r}72 \\
10 \\
4.8\end{array}$ & $\begin{array}{l}83 \\
11 \\
3.6\end{array}$ & $\begin{array}{r}71 \\
13 \\
5.9\end{array}$ & $\begin{array}{r}64 \\
11 \\
4.8\end{array}$ \\
\hline $\begin{array}{l}\text { SAND: } \\
\text { Very coarse } \\
\text { Coarse } \\
\text { Medium } \\
\text { Fine } \\
\text { Very fine }\end{array}$ & $\begin{array}{l}3.1 \\
3.1 \\
2.1 \\
2.4 \\
1.5\end{array}$ & $\begin{array}{r}1.4 \\
.4 \\
.3 \\
.2 \\
.0\end{array}$ & $\begin{array}{l}2.6 \\
1.8 \\
2.1 \\
1.7 \\
1.2\end{array}$ & $\begin{array}{l}2.6 \\
2.5 \\
2.7 \\
2.9 \\
5.2\end{array}$ \\
\hline $\begin{array}{l}\text { SILT: } \\
\text { Coarse } \\
\text { Medium-clay- }\end{array}$ & $\begin{array}{l}.6 \\
.4\end{array}$ & $\begin{array}{l}.0 \\
.1\end{array}$ & $\begin{array}{l}.3 \\
.4\end{array}$ & $\begin{array}{l}3.0 \\
1.3\end{array}$ \\
\hline Total- & 100 & 100 & 100 & 100 \\
\hline
\end{tabular}

WF-2 (lat $40^{\circ} 18^{\prime} 57^{\prime \prime}$ N., long $107^{\circ} 24^{\prime} 35^{\prime \prime}$ W. )

This site is on the South Fork of the Williams Fork, about one-fourth mile upstream from the confluence with the East Fork (main stem) and about 1.5 miles south of Pagoda (fig. 3). The site is at an altitude of about 6,600 feet. The vegetation is primarily cottonwoods, willows, and grasses, and 1 and is used for grazing of livestock and wildlife and for production of hay and crops. The river water is used for stock watering and irrigation. The bed material is fist-sized cobbles (not in table 3 ), with a mixture of sand and fine gravel (table 3 ). 
WF-3 (lat $40^{\circ} 22^{\prime} 17^{\prime \prime}$ N., long $107^{\circ} 33^{\prime} 56^{\prime \prime}$ W. )

This site on the Williams Fork is at an altitude of about 6,200 feet at the junction of Highway 13-789 and County Road 317 in Hamilton (fig. 3). The river at this point is within the lower end of a narrow steep-sided valley and enters a broader flood plain immediately downstream. The vegetation is willows, cottonwoods, and grasses. The bed material is composed of large material, including boulders mixed with cobbles (not in table 3 ), and is underlain by a mixture of gravel and sand (table 3 ).

WF-4 (1at $40^{\circ} 26^{\prime} 14^{\prime \prime}$ N., long $107^{\circ} 38^{\prime} 50^{\prime \prime}$ W.)

This is the downstream sampling site on the Williams Fork about 1,500 feet upstream from the confluence with the Yampa River (fig. 3), and 8 miles southwest of Craig ( $f i g .1$ ), at an altitude of about 6,200 feet. The vegetation consists primarily of willows and grass. Water from the Williams Fork at this site is used for limited irrigation of grasslands. The bed material ranges from small boulders to fist-sized cobbles (not in table 3 ), mixed with gravel, sand, and silt (table 3 ).

\section{North Platte River Basin}

Canadian River

CR-1 (lat $40^{\circ} 40^{\prime} 37^{\prime \prime}$ N., long $106^{\circ} 03^{\prime} 01^{\prime \prime}$ W. )

This upstream sampling site on the Canadian River is about 14 miles southeast of Walden, at an altitude of about 8,200 feet (fig. 1). The site is about 1.5 miles upstream from U.S. Geological Survey streamflow-gaging station 06619400 (fig. 4). The river channel is about 25 feet wide and flows within a broad valley of irrigated meadow and pasture land. The riparian vegetation consists primarily of grasses and willows. The river water is used for irrigation and stock and wildlife watering. The bed material is sand and gravel (table 4).

CR-2 (1at $40^{\circ} 48^{\prime} 29^{\prime \prime}$ N., long $106^{\circ} 14^{\prime} 09^{\prime \prime}$ W. )

This downstream sampling site on the Canadian River is at U.S. Geological Survey streamflow-gaging station 06619450 (fig. 4), about 5 miles north of Walden (fig. 1), at an altitude of about 7,900 feet. Upstream from the site are numerous diversions for irrigation of hay meadows. The natural flow is affected by return flows from these irrigated areas. The vegetation consists of grasses and brush, and the land is used for grazing except for the meadows which are used for hay production. Water from the river is primarily used for irrigation and watering stock. The site is also about 7 miles downstream from the McCallum District coal mining area, and in addition oil and gas wells are also present in the upper part of the basin. The bed material consists of finer-grained material than upstream and is predominantly a gravel and sand mixture (table 4). 
Table 4.--Mean percentage of size-graded bed-material samples collected from sites on the Canadian River

\begin{tabular}{|c|c|c|}
\hline \multirow{3}{*}{ Bed material } & \multicolumn{2}{|c|}{ Site number } \\
\hline & $\mathrm{Cr}-1$ & $\mathrm{Cr}-2$ \\
\hline & \multicolumn{2}{|c|}{ Percent of samples by weight } \\
\hline $\begin{array}{l}\text { GRAVEL: } \\
\text { Medium } \\
\text { Fine } \\
\quad \text { Very fine }\end{array}$ & $\begin{array}{r}65 \\
18 \\
5.6\end{array}$ & $\begin{array}{r}47 \\
14 \\
4.7\end{array}$ \\
\hline $\begin{array}{l}\text { SAND: } \\
\text { Very coarse } \\
\text { Coarse } \\
\text { Medium } \\
\text { Fine } \\
\text { Very fine }\end{array}$ & $\begin{array}{r}3.0 \\
2.3 \\
2.4 \\
2.4 \\
.9\end{array}$ & $\begin{array}{c}2.4 \\
2.3 \\
5.0 \\
13 \\
9.8\end{array}$ \\
\hline $\begin{array}{l}\text { SILT: } \\
\text { Coarse } \\
\text { Medium-clay }\end{array}$ & $\begin{array}{l}.2 \\
.2\end{array}$ & $\begin{array}{r}1.5 \\
.3\end{array}$ \\
\hline Total-non & 100 & 100 \\
\hline
\end{tabular}

\section{Little Grizzly Creek}

LGr-1 (lat $40^{\circ} 32^{\prime} 56^{\prime \prime}$ N., long $106^{\circ} 34^{\prime} 32^{\prime \prime}$ W. )

This upstream sampling site on Little Grizzly Creek (fig. 5) is at an altitude of about 8,500 feet and is about 25 miles southwest of walden (fig. 1). The site is upstream from all previous and potential coal mining operations. The creek at this site is less than 20 feet wide and flows within a valley covered with grass, willows, and brush. The land is used for ranching including grazing, and hay is grown in irrigated meadows. The bed material is composed of fist-sized cobbles (not in table 5), mixed with gravel and sand (table 5).

LGr-2 (lat $40^{\circ} 37^{\prime} 57^{\prime \prime}$, N., long $106^{\circ} 26^{\prime} 58^{\prime \prime}$ W.)

This downstream sampling site on Little Grizzly Creek is at U.S. Geological Survey streamflow-gaging station 06611900 (fig. 5). The site is at an altitude of about 8,100 feet and is 2.5 miles southwest of Hebron. This site lies downstream from the historical Coalmont mining area. Land uses are primarily agricultural including livestock grazing and irrigated crop production. The bed material is composed of fist-sized cobbles (not in table 5), mixed with fine sand and gravel (table 5). 
Table 5.--Mean percentage of size-graded bed-material samples collected from sites on Little Grizzly and Grizzly Creeks

\begin{tabular}{|c|c|c|c|}
\hline \multirow[t]{2}{*}{ Bed material } & \multicolumn{3}{|c|}{$\begin{array}{l}\text { Site number } \\
\text { LGr-2 }\end{array}$} \\
\hline & \multicolumn{3}{|c|}{ Percent of samples by weight } \\
\hline \multicolumn{4}{|l|}{ GRAVEL: } \\
\hline Medium-1 & 73 & 64 & 67 \\
\hline 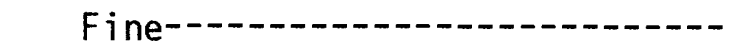 & 13 & 17 & 19 \\
\hline Very fine-- & 4.3 & 5.6 & 6.2 \\
\hline \multicolumn{4}{|l|}{ SAND: } \\
\hline Very coarse--1- & 2.9 & 3.2 & 2.7 \\
\hline Coarse---1-n & 2.4 & 3.2 & 1.8 \\
\hline 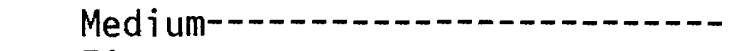 & 2.2 & 3.3 & 1.3 \\
\hline 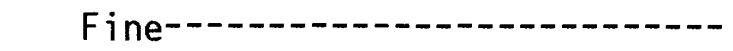 & 1.3 & 3.2 & 1.2 \\
\hline Very fine---1- & .5 & .4 & .4 \\
\hline \multicolumn{4}{|l|}{ SILT: } \\
\hline Coarse-1-n- & .2 & .0 & .2 \\
\hline Medium-clay-----1 & .2 & .1 & .2 \\
\hline Total--1- & 100 & 100 & 100 \\
\hline
\end{tabular}

\section{Grizzly Creek}

GR-1 (lat $40^{\circ} 33^{\prime} 27^{\prime \prime}$ N., long $106^{\circ} 23^{\prime} 22^{\prime \prime}$ W.)

This is the only sampling site on Grizzly Creek, at U.S. Geological Survey streamflow-gaging station 06611300 (fig. 5). This site is at an altitude of about 8,100 feet, and is about $3 \mathrm{miles}$ southeast of Hebron. The creek flows in a broad valley of grass and brush with meadows used for hay production and livestock grazing. The site is comprised of deep pools and a few riffles. Bed material in the pools is a fine silt and in the riffles is a mixture of sand and gravel (table 5).

\section{RESULTS AND DISCUSSION}

The basic data collected on streams in the Yampa River basin and North Platte River basin during the study are in Britton (1983). Included in Britton (1983) are the results of water-quality field measurements, the instantaneous discharge measurements (where available), and the tabulated benthic invertebrate data (including densities and taxa of organisms and diversity index calculations). 
A discussion of the taxonomic composition, seasonal trends, densities, and statistical analyses of the benthic invertebrate data given in Britton (1983) follows in this section for each stream reach sampled. Comparisons of benthic invertebrate results from past studies on similar stream reaches also are presented.

\section{Some General Concepts of Biological Analyses}

Benthic invertebrates or bottom fauna are studied because immediate responses to changes in water quality can be identified. Biological data do not replace chemical and physical data but only provide another line of evidence that supplements other water-quality data. If a short-term exposure of poor quality water occurs, organisms that cannot tolerate the stress are destroyed, and the community structure changes. This community structure will require time to return to its original condition even after the stress is removed. In other words, short-term exposures to pollution can be picked up by biological sampling, whereas they may be missed in chemical sampling.

In general, clean, unpolluted water will support many kinds of bottom fauna but, because of natural predation and competition effects, the number of individuals representing each kind will be low. Consequently, no one type of organism will dominate the community. This high diversity (many different kinds of organisms) lends stability to the aquatic system. However, most forms of stress (natural or man-induced) reduce or simplify the complexity of the aquatic ecosystem. Because bottom fauna vary greatly in their sensitivity to various types of pollution, the introduction of a pollutant or stress will reduce the number of species by eliminating those sensitive to the pollutant. Therefore, only those organisms that can survive adverse water-quality conditions will remain. These tolerant organisms generally increase in numbers because of the lack of competition and predation until checked by the amount of food and space available.

Even though no two bottom fauna organisms react equally to pollution, certain types of organisms are intolerant to various types of pollution. Therefore, some organisms are often associated with certain water-quality conditions. This is the indicator organism concept. In general, immature or larval stages of mayflies, stoneflies, caddisflies, riffle beetles, and hellgrammites are quite sensitive, and environmental changes will of ten cause their elimination (Cairns and Dickson, 1971). Pollution-tolerant organisms such as sludgeworms, certain midge (Diptera) larvae (bloodworms), leeches, and certain snails usually increase in number under polluted conditions. Organically enriched water can abound in organisms able to use atmospheric oxygen or have special modifications to survive under conditions of low oxygen tension (Diptera larval forms). Most snails, scuds, blackfly larvae, cranefly larvae, fingernail clams, dragonfly nymphs, and some midge larvae are intermediate in tolerance. However, tolerant organisms are found in both clean and polluted situations, and their presence does not mean a body of water is polluted; but a population of tolerant organisms combined with an absence of intolerant organisms is a good indication of pollution (Cairns and Dickson, 1971). 
Most groups of aquatic organisms are valuable indicator species. All groups have some merit as indicators, but none is adequate alone. The tendency now is to study the entire community as a unit in determining the health of a stream. Thus, a study of total populations and their composition is more useful. In addition to the presence of pollution-tolerant forms, the lack of clean water forms becomes an important indicator of polluted water. Relative numbers of individuals present in each species are thus more important than a simple listing of the presence of any one species. A continuation of this approach has been the development of biotic indices through the use of mathematical models.

The community diversity index is such a model based upon information theory that attempts to give a numerical value to environmental changes (Wilhm and Dorris, 1968). This diversity index takes into account the number of species (taxa) encountered and their relative abundance.

Initially, benthic invertebrate samples are collected and sorted into species or other taxonomic level, and the number of individuals within each taxa at each sampling site is counted. The diversity index (Wilhm and Dorris, 1968) is then calculated using the following formula:

$$
\mathrm{d}=-\sum_{i=1}^{s} \frac{n_{i}}{n} \quad \log _{2} \frac{n_{i}}{n}
$$

where:

$$
\begin{aligned}
\bar{d} & =\text { diversity index; } \\
n_{i} & =\text { number of individuals of each single taxa in the sample; } \\
n & =\text { total number of individuals of all taxa in the sample; } \\
s & =\text { total number of taxa. }
\end{aligned}
$$

The diversity index values range from 0 to some positive number. Maximum diversity occurs when each individual in the sample belongs to a different species, and minimum diversity occurs when all individuals belong to the same species. Generally, diversity index values less than 1 are indicative of severe pollution, values from 1 to 3 indicate moderate pollution, and values greater than 3 are characteristic of clean water areas (Goodnight, 1973).

Another index used to quantify differences is the index of percentage of similarity (0dum, 1971). This index facilitates a meaningful comparison of taxa between various sites. However, the index does not take into account the relative abundance of taxa. The reported fauna (taxa) are compared between sites using the following formula: 


$$
S=\frac{2 c}{a+b}
$$

where:

$$
\begin{aligned}
& S=\text { similarity index } \\
& a=\text { number of species in sample or site } a ; \\
& b=\text { number of species in sample or site } b ; \\
& c=\text { number of species common to both samples or sites. }
\end{aligned}
$$

The similarity index values lie between 0 and 1 ( 0 and 100 percent); the closer the value to 1 , the greater the similarity in taxonomic composition between samples or sites.

Functional feeding groups of the community as well as taxonomic composition and densities of the benthic invertebrates can be useful in describing the morphological characteristics of a stream (Cummins and Klug, 1979). Benthic invertebrates generally can be categorized into five distinct functional feeding groups. Shredders are the organisms which feed on decaying plant material such as leaf litter. Scrapers or grazers feed on living material such as periphyton that is attached to submersed surfaces like rocks and logs. Collectors are divided into two subcategories--the gatherers and the filterers. The collector-gatherers harvest small particles of deposited detritus, such as organic debris from bacterial decomposition products. The collector-filterers feed on detrital particles in suspension. Predators feed on other living animals.

\section{Trout Creek}

\section{Physical and Chemical Water Quality}

Water-quality field measurements and discharge data for Trout Creek are in Britton (1983). A summary showing means (median for $\mathrm{pH}$ ) and ranges of these water-quality measurements is in table 6 .

Specific conductance was always greater at site $\mathrm{Tr}-3$ than at the upstream sites. This increase was probably a combination of two factors. One was the increase in agricultural practices downstream, such as irrigation, which may have had an enriching effect on the stream causing greater amounts of soluble salts at site $\mathrm{Tr}-3$. The second factor for the increase in conductivity was probably due to leaching of soluble salts from the overburden strip-mining operations upstream. The $\mathrm{pH}$ values at these sites ranged from 7.5 to 8.7 . Unlike drainage from coal mining in the Eastern United States, western stream waters draining coal mines are well buffered, and major inputs of acid or base would be required to shift the pH significantly (Canton and Ward, 1978). Higher water temperatures at the downstream site $(\mathrm{Tr}-3)$ did not appear to affect the dissolved oxygen concentration; in fact, the dissolved oxygen was more often supersaturated at site $\mathrm{Tr}-3$ than at the upstream sites. 
Table 6.--Summary of water-quality constituents and properties measured from sites on Trout Creek

$\left[{ }^{\circ} \mathrm{C}\right.$, degree Celsius; $\mu$ mho, micromhos per centimeter at $25^{\circ} \mathrm{C}$; $\mathrm{mg} / \mathrm{L}$, milligrams per liter]

\begin{tabular}{|c|c|c|c|c|c|c|c|c|}
\hline \multirow[t]{2}{*}{ Sites } & \multicolumn{2}{|c|}{$\begin{array}{c}\text { Water } \\
\text { temperature } \\
\left({ }^{\circ} \mathrm{C}\right)\end{array}$} & \multicolumn{2}{|c|}{$\begin{array}{c}\mathrm{pH} \\
\text { (units) }\end{array}$} & \multicolumn{2}{|c|}{$\begin{array}{c}\text { Specific } \\
\text { conductance } \\
(\mu \mathrm{mho})\end{array}$} & \multicolumn{2}{|c|}{$\begin{array}{c}\text { Dissolved } \\
\text { oxygen } \\
\text { (mg/L) }\end{array}$} \\
\hline & Mean & Range & Median & Range & Mean & Range & Mean & Range \\
\hline Tr-1--- & 11.3 & $0.0-18.8$ & 8.0 & $7.6-8.5$ & 205 & $142-275$ & 8.4 & $7.2-11.2$ \\
\hline Tr-2--- & 11.6 & $0.0-17.9$ & 8.0 & $7.6-8.7$ & 218 & $151-290$ & 8.3 & $7.3-10.6$ \\
\hline Tr-3- - & 15.8 & $0.0-25.3$ & 8.2 & $8.0-8.6$ & 514 & $369-600$ & 8.4 & $6.4-12.1$ \\
\hline
\end{tabular}

A size classification of bed material samples collected from the Trout Creek sites is presented in table 1 but does not depict the actual differences between the three sites. Sampling of benthic invertebrates and observations indicated that site $\mathrm{Tr}-3$ had a greater percentage of fine material than the upstream sites. A study conducted over two 2-week intervals using jars placed on the stream bottom at similar sites on Trout Creek showed as much as a threefold increase in sediment deposition at the lower site (near $\operatorname{Tr}-3$ ) compared with a site directly downstream from the mine spoils (Harner-White Ecological Consultants, oral commun., 1982). These data indicate that increased sediment deposition was probably the result of agricultural activities as opposed to mining effects, because sediment deposition at the site directly downstream from the mine spoils was not greater than at the upstream control site.

\section{Benthic Invertebrate Composition and 0ccurrence}

There were 71 benthic invertebrate taxa identified at site $\operatorname{Tr}^{-1}, 77$ at site $\mathrm{Tr}-2$, and 78 at site Tr-3 (Britton, 1983). The increase in number of taxa downstream was partly because of increases in the number of taxa in the Diptera (true fly) order. The ranges and means of the percentage composition of major taxonomic groups at each site are shown in figure 6 . The percentage of Diptera increased downstream from a mean of 16 percent at site Tr-1 to 55 percent at site $\mathrm{Tr}-3$. In conjunction with this increase, the percentage of Trichoptera (caddisfly) decreased from a mean of 40 percent at site $\mathrm{Tr}^{-1}$ to 14 percent at site $\mathrm{Tr}-3$. 

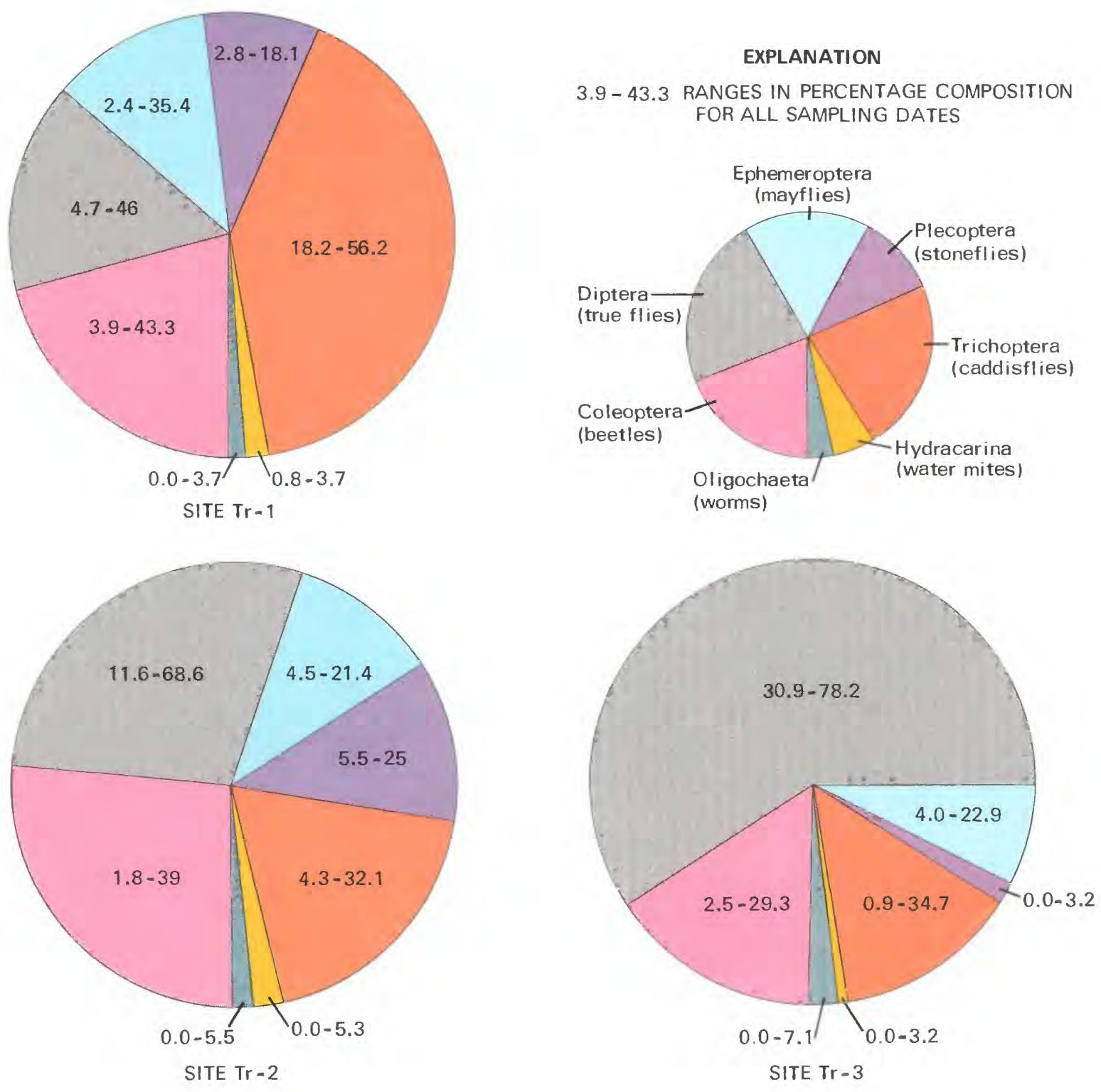

Figure 6.-- Mean percentage composition of major benthic invertebrate taxonomic groups collected from sites on Trout Creek for all sampling dates. 
On all sampling dates the five orders of aquatic insects--Coleoptera (beetles); Diptera (true flies); Ephemeroptera (mayflies); Plecoptera (stoneflies); and Trichoptera (caddisflies)--comprised wel1 over 90 percent of the mean density of organisms. A caddisfly (Lepidostoma) was the most frequently occurring and abundant organism collected at site $\mathrm{Tr}^{-1}$. Two beetles (Zaitzevia parvula and optioservus castanipennis) were found as frequently but less abundantly. These two beetles were again the most abundant organisms collected at site $\mathrm{Tr}-2$, but a chironomid (Chironomidae Form 1) of the order Diptera was the next most dominant organism collected at this site. At site $\mathrm{Tr}-3$, downstream from all coal mining, the same chironomid was the most abundantly found organism followed by the beetle optioservus castanipennis, and another chironomid (Chironomidae Form 3).

Along with changes in species composition of the benthic invertebrates, there were also differences in functional (feeding groups) aspects of the Trout creek community. The relative abundance of the functional groups is shown for al1 Trout Creek sites in table 7. Differences in the functional structure of the benthic communities can be related to minor differences in environmental conditions. The most obvious trend indicated in table 7 is the decrease in shredders (such as the caddisfly Lepidostoma) downstream combined with an increase in collectors. For example, the dominant shredder (Lepidostoma) was replaced by collector-filterer caddisflies such as Hydropsyche and Cheumatopsyche. More extensive woody riparian vegetation at upstream sites may account for some of the variation. Leaf 1itter is less abundant downstream as Trout Creek changes from a shaded headwater stream to a more open lowland stream where the food base consists of more algae and particulate organic detritus imported from upstream. The result is a shift from a more balanced functional community at site $\mathrm{Tr}^{-1}$ to a community at site $\mathrm{Tr}-3$ comprised heavily of collector-type organisms, such as Diptera, that feed on suspended and deposited detritus. The reduced importance of shredders relative to collectors in streams such as Trout Creek, which increase in size downstream, is a feature of most eastern deciduous forest and western montane streams (Cummins and Kiug, 1979).

Table 7.--Relative abundance of benthic invertebrate functional groups collected from sites on Trout creek

\begin{tabular}{|c|c|c|c|}
\hline \multirow{2}{*}{ Functional group } & \multicolumn{3}{|c|}{ Percentage of total } \\
\hline & $\operatorname{Tr}-1$ & $\operatorname{Tr}-2$ & $\operatorname{Tr}-3$ \\
\hline Shredders & 34 & 13 & 8 \\
\hline Grazers- & 20 & 20 & 15 \\
\hline Collectors-gatherers-_- & 30 & 42 & 53 \\
\hline Collectors - filterers & 5 & 12 & 18 \\
\hline Predators & 11 & 13 & 6 \\
\hline Total- & 100 & 100 & 100 \\
\hline
\end{tabular}


Faunal taxa present at each site were compared using an index of percentage similarity (Odum, 1971). The number of species at one site was compared with the number of species at another site until taxonomic composition at all sites had been compared. The mean and ranges in similarity indices between the Trout Creek sites is shown in table 8 . Sites $\mathrm{Tr}-1$ and $\mathrm{Tr}-2$ had the most similar taxa, while sites $\mathrm{Tr}-1$ and $\mathrm{Tr}-3$ had the least similar taxa. This is partly because sites $T r-1$ and $T r-2$ are physically nearest to each other and sites $\mathrm{Tr}-1$ and $\mathrm{Tr}-3$ are the furthest apart. However, as will be discussed later, physical and chemical water-quality differences may also have had an effect. The greatest similarity in taxonomic composition between sites was in November 1980, whereas the least similarity was in June and July 1981. Similarity was least during the summer because similarity is affected by scour during spring runoff and by emergence of adult organisms.

Table 8.--Similarity indices for benthic invertebrates collected from sites on Trout Creek

\begin{tabular}{|c|c|c|c|c|c|c|}
\hline \multirow{2}{*}{ Site } & \multicolumn{2}{|c|}{$T r-1$} & \multicolumn{2}{|c|}{$T r-2$} & \multicolumn{2}{|c|}{$\operatorname{Tr}-3$} \\
\hline & Mean & Range & Mean & Range & Mean & Range \\
\hline Tr-1 $1-\cdots$ & --- & $-\cdots$ & 0.77 & $0.68-0.88$ & 0.54 & $0.39-0.70$ \\
\hline Tr $-2-\cdots-\cdots$ & 0.77 & $0.68-0.88$ & $\cdots$ & ---- & .57 & $.40-.71$ \\
\hline Tr-3- $-\cdots$ & .54 & $.39-.70$ & .57 & $.40-.71$ & --- & ---- \\
\hline
\end{tabular}

Changes in percentage composition of the major taxonomic groups between sampling dates are shown in figure 7. At site $\mathrm{Tr}-1$, Trichoptera were dominant during late summer and early fall, but Ephemeroptera, Diptera, and Coleoptera dominated the percentage composition on at least one sampling date. These fluctuations are a function of life-cycle stages of the organisms, but also indicate that this site provides habitat for the development of several groups of organisms. At site $\mathrm{Tr}-2$, there again was some fluctuation in dominance of the major groups of organisms. In April and September 1981, the density of Diptera reached a peak, and Coleoptera and Trichoptera dominated the composition for the remainder of the sampling dates. However, as at site $\operatorname{Tr}-1, a$ taxonomic group rarely comprised more than 50 percent of the composition. Seasonal trends and taxonomic composition differed considerably at site Tr-3. Diptera dominated the composition on all sampling dates except September 1981 and comprised more than 50 percent of the composition on five of the eight sampling dates. The higher percentage of Diptera is primarily because of greater midge larvae density at this site. Midges can often complete many generations in the warmer, lower reaches of a stream like Trout Creek and maintain high numbers through recruitment of larvae during the summer and fall as a result of multiple adult emergence. 

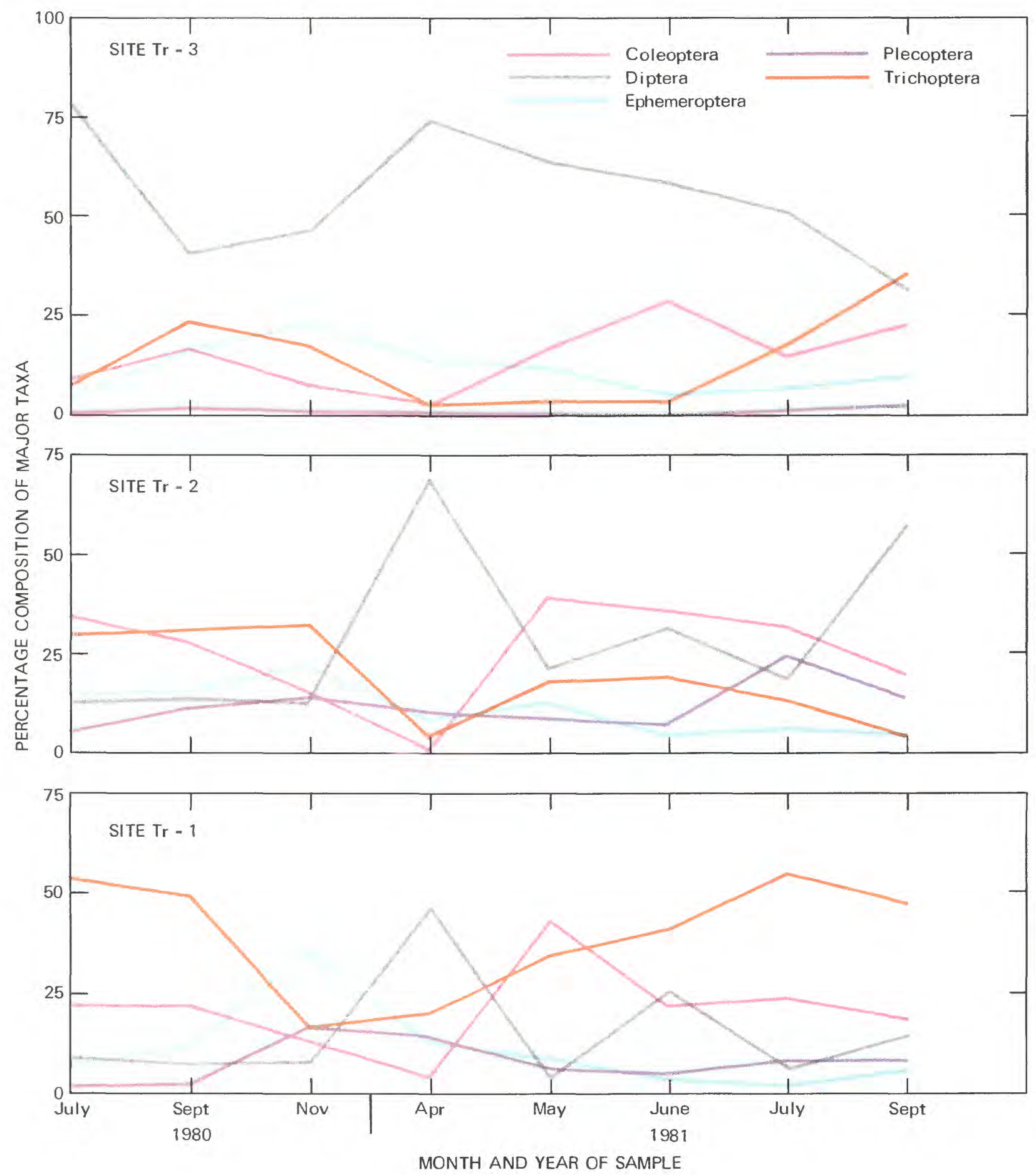

Figure 7.-- Percentage composition of major benthic invertebrate taxonomic groups collected from sites on Trout Creek. 
Organism densities per square meter at the Trout Creek sites, along with number of taxa collected on each sampling date, are shown in figure 8 . Generally, in Colorado streams invertebrate densities are low in late spring and early summer due to emergence of adults and the effects of scour from spring runoff. This low is followed by an increase through the summer and fall as larvae hatch from eggs laid during the summer. Organism density is often at a maximum in late fall followed by a general decline through the winter due to the severe effects of ice formation and little organism replacement. Benthic invertebrate density in Trout Creek did not follow this pattern. At site $\mathrm{Tr}^{-1}$, the lowest numbers of organisms were found in April, and numbers continued to increase through June but decreased in July, possibly because of scour from heavy rains prior to sampling. At site $\mathrm{Tr}-2$, lowest numbers of organisms were in July 1980 and July 1981 and highest numbers in June and September, which is similar to the upstream site. Site $\mathrm{Tr}-3$ showed three peaks in organism density in November 1980 and May and July 1981. Dominance of Diptera taxa at this site, and their ability to complete several life cycles, may explain this alternating pattern.

Generally, the density of organisms per square meter increased downstream from a mean of 6,300 organisms at site $\mathrm{Tr}-1$, to 6,400 at site $\mathrm{Tr}-2$, and to nearly 13,000 at site $\mathrm{Tr}-3$. In conjunction with this increase, the mean density of Diptera per square meter increased from 990 organisms at site $\mathrm{Tr}-1$, to 1,800 at site $\mathrm{Tr}-2$, and to 7,000 at site $\mathrm{Tr}-3$. The mean density of Trichoptera per square meter varied from 2,600 organisms at site Tr-1, to 1,200 at site $\mathrm{Tr}-2$, and to 1,700 at site $\mathrm{Tr}-3$.

Species diversity was used as another tool to quantify differences in the biological quality of Trout Creek. Species diversity indices shown in table 9 conform to those typically found in clean water streams (Wilhm, 1970), in which there is little apparent difference between sites. As will be discussed later, these indices do not accurately depict differences in the biotic community of Trout Creek.

Table 9.--species diversity indices for benthic invertebrates collected from sites on Trout Creek

\begin{tabular}{|c|c|c|c|c|c|}
\hline \multirow{3}{*}{ Site } & \multicolumn{5}{|c|}{ Diversity Index (d) } \\
\hline & \multirow{2}{*}{ Mean } & \multicolumn{4}{|c|}{ Range } \\
\hline & & Minimum & (Date) & Maximum & (Date) \\
\hline 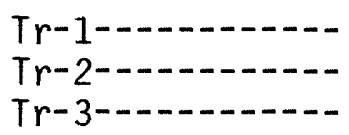 & $\begin{array}{l}3.32 \\
3.69 \\
3.36\end{array}$ & $\begin{array}{l}2.61 \\
3.28 \\
2.58\end{array}$ & $\begin{array}{l}(5-81) \\
(6-81) \\
(7-80)\end{array}$ & $\begin{array}{l}4.00 \\
4.20 \\
3.79\end{array}$ & $\begin{array}{r}(11-80) \\
(11-80) \\
(9-80)\end{array}$ \\
\hline
\end{tabular}



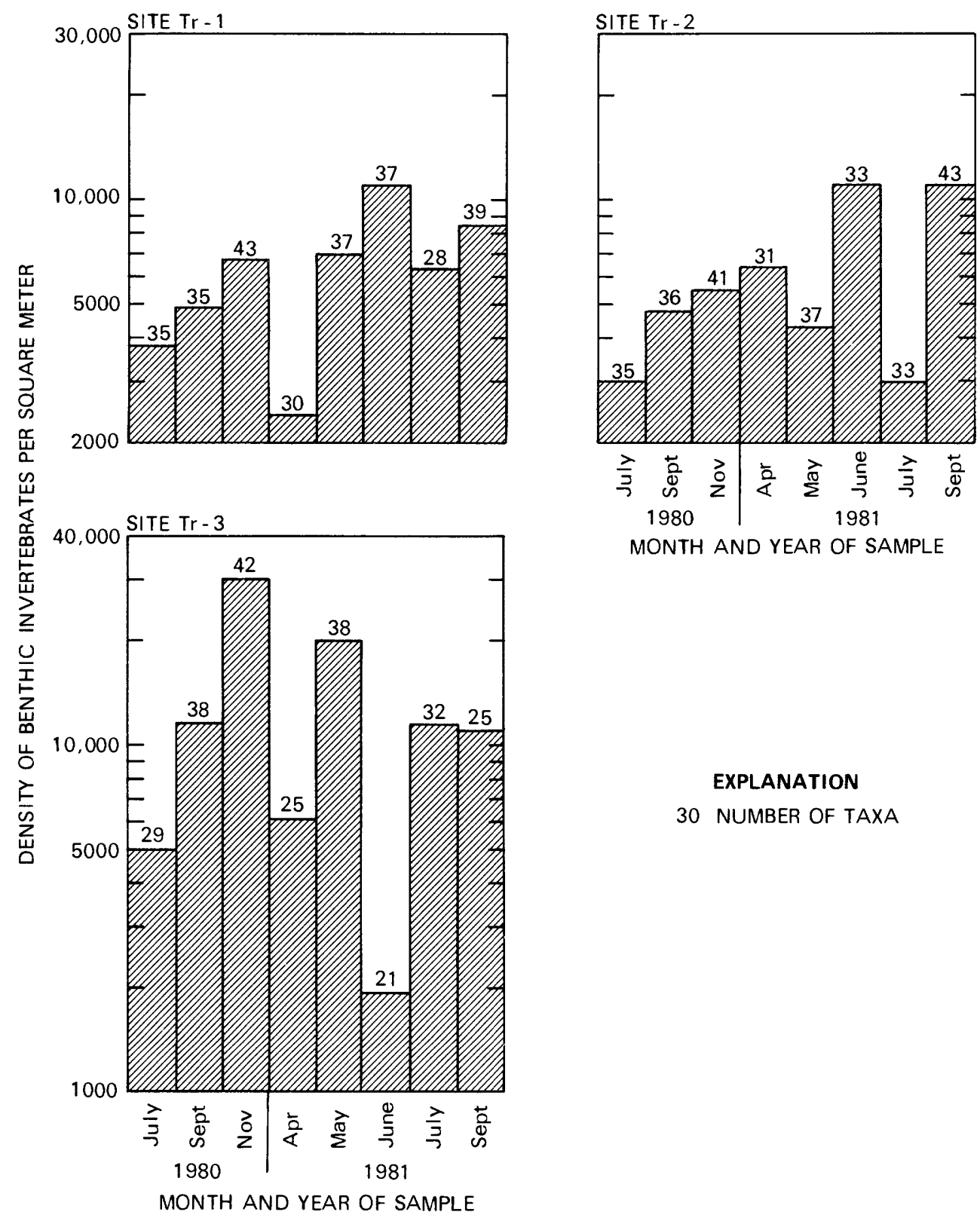

EXPLANATION

30 NUMBER OF TAXA

Figure 8.--Density of benthic invertebrates and taxa, per square meter, collected from sites on Trout Creek. 


\section{Statistical Analyses}

The benthic invertebrate data were tested using several statistical techniques. The data were analyzed for normality, and in the case of Trout Creek, benthic invertebrate densities were less skewed after transformation to the $\log$ base 10 . Therefore, all statistical testing of benthic invertebrate densities was done on transformed data. All tests were performed at the 95-percent probability level.

An analysis of variance was run on the transformed densities to determine if there was a significant difference in densities among the three sites. Testing the mean densities on individual dates showed that there were significant differences between sites $\mathrm{Tr}^{-1}$ and $\mathrm{Tr}-2$ in Apri1, May, and July 1981. The means between sites $\mathrm{Tr}-1$ and $\mathrm{Tr}-3$ were significantly different for all dates except July 1980. Mean densities between sites $\mathrm{Tr}-2$ and $\mathrm{Tr}-3$ were significantly different on all dates except April and September 1981. Summarizing the statistical results for all dates showed that mean densities from site $\mathrm{Tr}-3$ were significantly higher than sites $\mathrm{Tr}-1$ and $\mathrm{Tr}-2$, while the mean densities between sites $\mathrm{Tr}-1$ and $\mathrm{Tr}-2$ were not significantly different. An assessment of seasonal or sampling date variations showed significant differences in mean densities for all sites combined on individual sampling dates. Therefore, significant differences occurred between dates, as well as between and within sites on different sampling dates.

An evaluation was also made of the effect of replicate samples. A t-test was run on the benthic invertebrate densities collected in replicate samples for all sites and dates. At sites $\mathrm{Tr}^{-1}$ and $\mathrm{Tr}-2$ densities determined in replicate samples were significantly different only for the November 1980 sampling date. There were no significant differences of replicate sample densities collected at site $\mathrm{Tr}-3$. In addition, there were no significant differences in mean number of taxa collected in replicate samples at Trout Creek sites.

The analysis of variance procedure also showed that there were no significant differences in number of taxa between the Trout Creek sites. In addition, only 5 percent of the variation in taxa was related to site, whereas 95 percent was related to sampling date. However, figure 7 shows that there were distinct differences in the taxonomic composition, especially between upstream sites $(T r-1, T r-2)$ and the downstream site $(T r-3)$.

In summary, the analysis of variance and t-test results indicated significant variations in densities of benthic invertebrates at different sites and on different sampling dates. The analysis of variance model showed more than 50 percent of the variation in mean densities was due to sampling date differences within and between sites, and about 47 percent of the variation in mean densities was due to differences in replicate samples and to sampling and analytical error. The remaining 3 percent was due to differences in densities between sites. 
The log-transformed benthic invertebrate densities were correlated with each measured water-quality constituent or property to determine if there was a significant relationship. At site $\mathrm{Tr}^{-1}$, the best correlation obtained was with specific conductance. The correlation coefficient ( $r$ ) was 0.40 . This correlation, however, was not significant. A better correlation was obtained using a model consisting of four independent variables. Specific conductance, $\mathrm{pH}$, dissolved oxygen, and temperature were correlated with densities, which resulted in a significant correlation having an $r$-value of 0.76 . The $r$-square value of 0.58 indicated that 58 percent of the variation in benthic invertebrate densities at site $\mathrm{Tr}-1$ was associated with these four water-quality variables.

At site $\mathrm{Tr}-2$, benthic invertebrate densities correlated best with $\mathrm{pH}$ $(r=-.47)$, but this was not a significant correlation. A stepwise regression model correlating $\mathrm{pH}$, temperature, and specific conductance with densities, gave a calculated $r$-value of 0.60 . The determined r-square value of 0.36 indicated that 36 percent of the variation in benthic invertebrate densities was associated with these three water-quality variables.

At site $\mathrm{Tr}-3$, correlation of temperature and dissolved oxygen with benthic invertebrate densities yielded correlation coefficients of -0.71 and 0.69 respectively; both relationships were significant. A stepwise modeling procedure indicated that the four independent variables (temperature, $\mathrm{pH}$, specific conductance, and dissolved oxygen) provided the best correlation, which resulted in an $r$-value of 0.99 . The $r$-square value of 0.98 indicated that 98 percent of the variation in densities of benthic invertebrates was associated with these four water-quality variables.

\section{Comparison with Other Studies}

Results of previous studies conducted on Trout Creek, beginning in July 1975 and continuing to 1980, are used as comparison for assessing possible changes in the benthic invertebrate community, as well as effectiveness and agreement on sampling techniques. Canton and Ward (1977, 1978, 1981) and Ward and others (1978) present results from a study conducted on Trout Creek from July 1975 through April 1977. The study included sampling of seven sites (upstream and downstream from the Edna Mine), of which three were similar to the sites sampled in this study. For comparative purposes, it will be assumed that the numbered sites sampled in the present study coincide with similar sites sampled in previous investigations by others. They collected multiple samples at each site using a Surber sampler having a 700- $\mu \mathrm{m}$ mesh net, as compared with a $210-\mu \mathrm{m}$ mesh net used in this study.

The composition of benthic invertebrates collected in the 1975-1977 study was similar to the present study, and more than 90 percent of the density at all sites was comprised of aquatic insects. As in the present study, the densities were greater downstream. Canton and Ward (1977, 1978, 1981) and Ward and others (1978) concluded that this increase was probably due to the enriching effect of agricultural practices upstream, such as irrigation. However, mean densities were greater at each site during the present study, and the increase was probably due to the use of a net having a smaller mesh size which enabled more organisms, especially the smaller varieties, to be captured. 
The major difference in results of the present study and the 1975-1977 study was the change in taxonomic composition. In the 1975-1977 study, Trichoptera dominated the composition at all sites, although there was a similar decrease in percentage composition of Trichoptera from site $\mathrm{Tr}^{-1}$ to site Tr-2. Canton and Ward (1977, 1978, 1981) and Ward and others (1978) concluded that this decrease may have been due to effects of drainage from a coal mine upstream from site $\mathrm{Tr}-2$. As in the present study, the caddisfly Lepidostoma and elmid beetles dominated the composition at the upstream site. In conjunction with a decrease in percentage of Trichoptera, there was an increase in percentage of Diptera at site $\mathrm{Tr}-2$; a change similar to that found in this study. However, in the 1975-1977 study, Trichoptera continued to dominate even at the furthest downstream site $(\mathrm{Tr}-3)$, whereas, Diptera dominated the composition and comprised more than 50 percent of the composition at site $\mathrm{Tr}-3$ on nearly all sampling dates of the present study. These differences were probably due to the smaller mesh size of the Surber sampler used in the present study which captured smaller organisms, such as chironomids.

Chadwick and Canton (1983) also conducted a study on Trout Creek and sampled quarterly from August 1979 to April 1980 at four sites (two of which coincide with $\mathrm{Tr}-2$ and $\mathrm{Tr}-3$ ). They also used a Surber sampler having a $700-\mu \mathrm{m}$ mesh net. Mean densities obtained in the present study were about 20 percent higher than those found in the 1979-1980 study, again probably due to the differences in mesh size of the sampling net. The trend of increasing densities downstream, however, was found in both studies. In contrast to the present study, Trichoptera dominated the density at all sites, although the study did show a downstream increase in Diptera at a station near site $\mathrm{Tr}-3$. There was also a similar shift from the shredder Lepidostoma and scraper-type Glossosoma caddisflies at the upstream site to filter-feeding collector caddisflies such as Hydropsyche and Cheumatopsyche at the downstream site.

As in the present study, specific conductance also was greater downstream, especially at the most downstream site. Unlike the present study, Chadwick and Canton (1983) found organism density and biomass were significantly correlated $(r=0.9)$ with specific conductance. Like the present study, the taxonomic composition varied between sites, but the diversity indices did not reflect these differences with very little change in diversity index values between sites. Diversity index values were comparable to those obtained in this study and fell within the normal range for clean-water streams defined by Wilhm (1970).

Relative abundance and trend of functional groups collected at sites $\mathrm{Tr}-2$ and $\mathrm{Tr}-3$ in the Chadwick and Canton (1983) study were nearly identical to those of the present study. They found a similar change in functional structure from shredder-type organisms to collector-type organisms and concluded that this change was a function of environmental and physical changes in the character of Trout Creek downstream rather than a decrease in water quality. 
Canton and Ward (1977, 1978, 1981), Ward and others (1978) and Chadwick and Canton (1983) concluded that the Edna Mine (between sites Tr-2 and Tr-3) had only a mild effect on the biota of Trout Creek, and settling ponds and a substantial buffer zone of unmined land adjacent to the stream were primary factors minimizing adverse effects.

\section{Fish Creek}

Physical and Chemical Water Quality

Water-quality field measurements and discharge data for Fish Creek are in Britton (1983). A summary showing means (median for $\mathrm{pH}$ ) and ranges of these water-quality measurements is in table 10.

Table 10.--Summary of water-quality constituents and properties measured from sites on Fish Creek

$\left[{ }^{\circ} \mathrm{C}\right.$, degree Celsius; $\mu$ mho, micromhos per centimeter at $25^{\circ} \mathrm{C}$; $\mathrm{mg} / \mathrm{L}$, milligrams per liter]

\begin{tabular}{lrrrrrrrr}
\hline Site & $\begin{array}{c}\text { Water } \\
\text { temperature } \\
\left({ }^{\circ} \mathrm{C}\right)\end{array}$ & \multicolumn{2}{c}{$\begin{array}{c}\text { Specific } \\
\text { conductance } \\
(\mu \mathrm{mho})\end{array}$} & $\begin{array}{c}\mathrm{pH} \\
(\text { units })\end{array}$ & \multicolumn{2}{c}{$\begin{array}{c}\text { Dissolved } \\
\text { oxygen } \\
(\mathrm{mg} / \mathrm{L})\end{array}$} \\
\cline { 2 - 9 } & Mean & Range & Mean & Range & Median & Range & Mean & Range \\
\hline F-1-- & 12.4 & $0.0-24.5$ & 582 & $262-812$ & 8.4 & $7.9-8.8$ & 8.6 & $6.5-11.1$ \\
F-2-- & 16.1 & $.5-24.2$ & 713 & $585-808$ & 8.1 & $7.9-8.7$ & 8.2 & $6.9-12.6$ \\
F-3-- & 17.5 & $.8-27.0$ & 785 & $370-970$ & 8.3 & $7.9-8.7$ & 8.6 & $4.7-11.9$ \\
\hline
\end{tabular}

In general, water temperature and specific conductance increased downstream. The increase in water temperature was because of decreasing elevation and cover or shade at the downstream sites. The increase in specific conductance was probably due to changes in land use including the increased development of irrigation and other agricultural activities, and mined lands (U.S. Department of Agriculture, 1981). Dissolved oxygen concentrations were nearly always saturated or supersaturated at the three sites, but the low value of 4.7 milligrams per liter measured at site $\mathrm{F}-3$ was less than the limit recommended to sustain a well-balanced aquatic fauna (U.S. Environmental Protection Agency, 1977).

A size classification of bed material samples collected from Fish Creek sites is presented in table 2. The analysis shows very little difference in sediment size between the sites, but sampling observations indicated that larger material (greater than gravel-size material) is more abundant at the upstream site $(F-1)$ than the downstream sites $(F-2, F-3)$. 
Benthic Invertebrate Composition and Occurrence

There were 70 benthic invertebrate taxa identified at site $F-1,64$ at site F-2, and 64 at site F-3 (Britton, 1983). Ranges and means of the percentage composition of major taxonomic groups at each site are shown in figure 9. The percentage of Diptera increased downstream from a mean of 38 percent at site $\mathrm{F}-1$ to 51 percent at site $\mathrm{F}-3$. In conjunction with this increase, the percentage of Coleoptera decreased from a mean of 12 percent at site $\mathrm{F}-1$ to about 4 percent at site $\mathrm{F}-2$.

On most sampling dates, five orders of aquatic insects (Coleoptera, Diptera, Ephemeroptera, Plecoptera, and Trichoptera) comprised well over 90 percent of the mean density. However, during the early summer months of 1981 an aquatic worm (Limodrilus) of the class 01 igochaeta comprised from 12 to 48 percent of the taxonomic composition at site F-1 and 7 to 31 percent at site F-3. Limnodrilus is adapted to burrowing in soft sediments and is able to withstand considerable oxygen depletion in its environment. According to Brinkhurst and Cook (1974), this organism is very resistant and tolerant of pollution and is often considered an indicator species. However, they also warn that studies have shown Limnodrilus to be present in clean-water environments as well. The habitat provided by Fish Creek does provide the sediment conditions needed by Limnodrilus which will ingest large volumes of sediment continuously in order to extract the nutrient material.

A Chironomid (Chironomidae Form 1), a beetle (optioservus castanipennis), and a caddisfly (Hydropsyche) were the most frequently collected and abundant organisms at site $\mathrm{F}-1$. Limnodrilus was not collected during every sampling date, but had the highest mean concentration at this site. Chironomidae Form 1 was the most frequently occurring and abundant organism at site F-2, followed by a mayfly (Tricorythodes) and a caddisfly (Cheumatopsyche). Another Diptera (simulium arcticum) also was found in high concentrations at this site. Chironomidae Form 1 was again the most frequently occurring organism collected at site F-3. Simulium arcticum and Limnodrilus were present in higher mean concentrations but were collected less frequently.

Not only did species composition change between sites, but functional groups differed between sites as well (table 11). An obvious trend was the increase of collector-filterers and decrease of collector-gatherers at site $\mathrm{F}-3$, as compared with upstream sites. This trend is accounted for by the morphological and land use changes that occur at site F-3. Upstream from site F-3, runoff from agricultural lands probably provide favorable conditions for collector-filterers which can feed on the large amounts of sediment that are transported downstream. The associated decreasing importance of grazers (predominantly beetles) at the two downstream sites again points out differences in environmental conditions between sites, because there is no habitat provided for attached periphyton on which organisms can graze.

Faunal taxa present at each site were compared using the index of percentage similarity. Mean and ranges in similarity indices between Fish Creek sites are shown in table 12 . Sites $F-2$ and $F-3$ had the most similar taxa, and site $\mathrm{F}-1$ and $\mathrm{F}-3$ had the least similar taxa. 


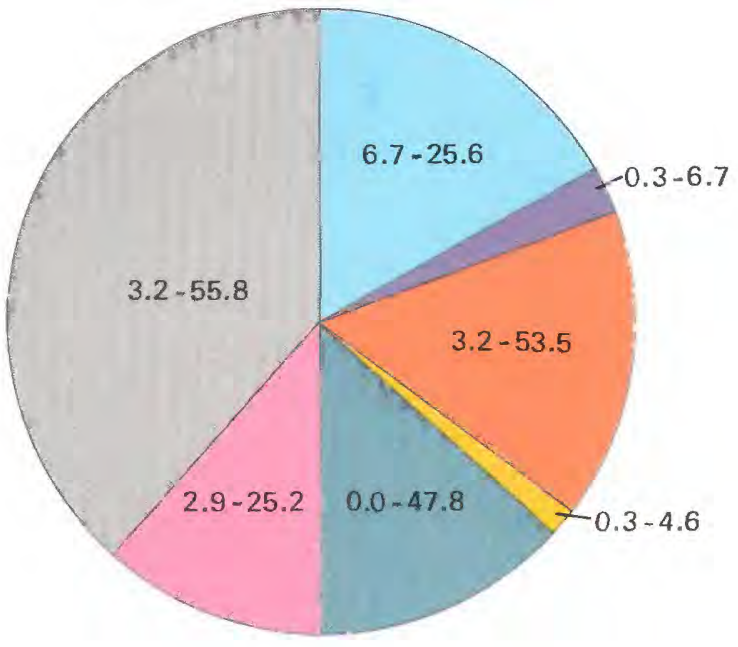

SITE F-1

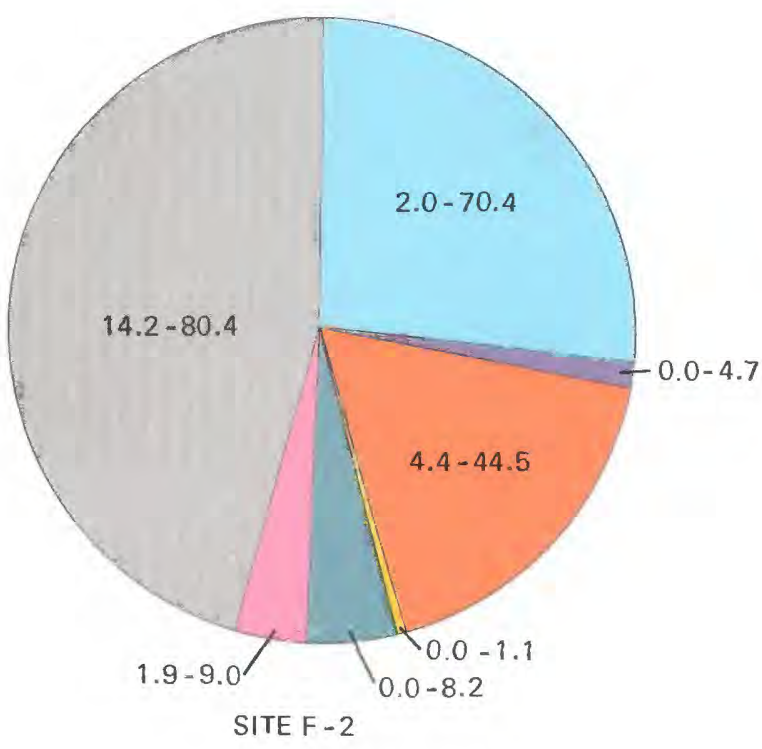

\section{EXPLANATION}

14.2 - 80.4 RANGES IN PERCENTAGE COMPOSITION FOR ALL SAMPLING DATES
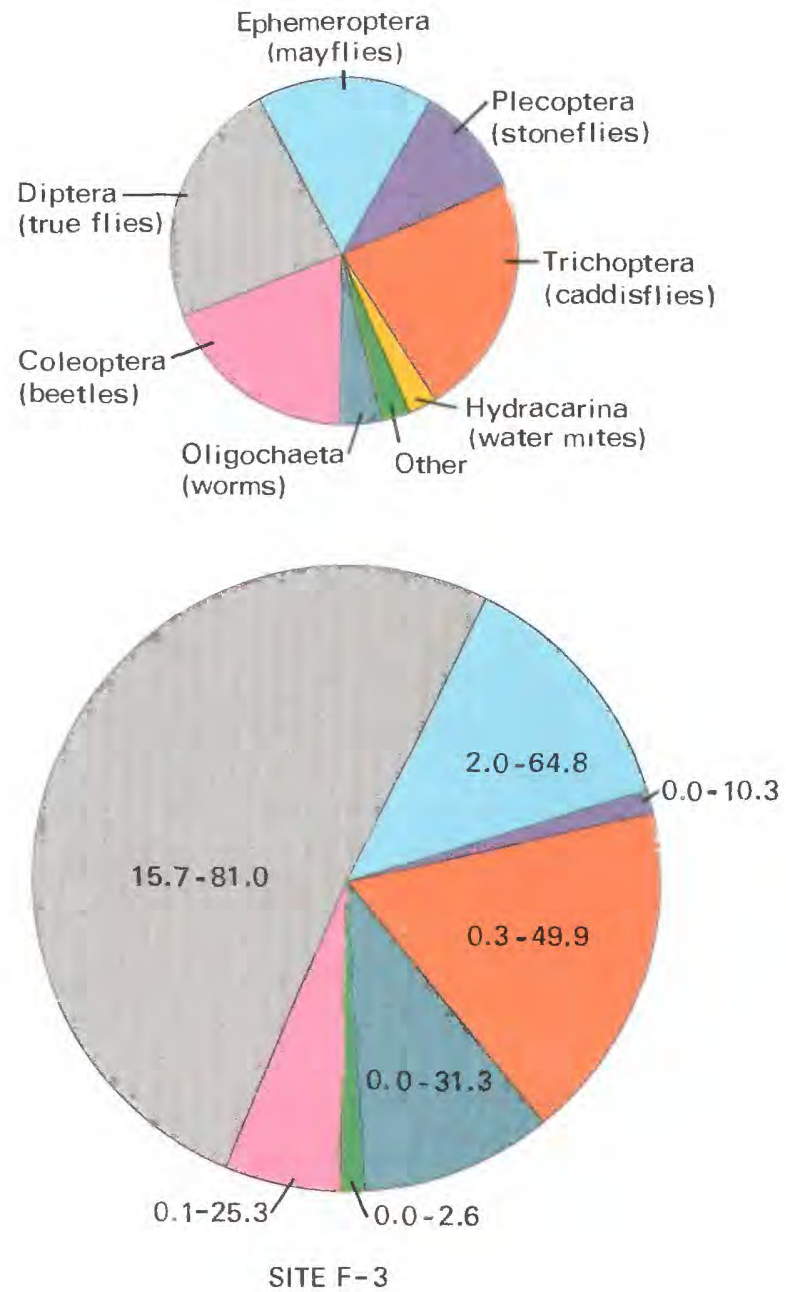

Figure 9.-- Mean percentage composition of major benthic invertebrate taxonomic groups collected from sites on Fish Creek for all sampling dates. 
Table 11.--Relative abundance of benthic invertebrate functional groups collected from sites on Fish Creek

\begin{tabular}{|c|c|c|c|}
\hline \multirow{2}{*}{ Functional group } & \multicolumn{3}{|c|}{ Percentage of total } \\
\hline & $\mathrm{F}-1$ & $\mathrm{~F}-2$ & $\mathrm{~F}-3$ \\
\hline Shredders & 5 & 8 & 9 \\
\hline Grazers & 13 & 2 & $<1$ \\
\hline Collectors-gatherers & 55 & 57 & 36 \\
\hline Collectors-filterers & 20 & 29 & 50 \\
\hline Predators & 7 & 4 & 5 \\
\hline Total- & 100 & 100 & 100 \\
\hline
\end{tabular}

Table 12.--Similarity indices for benthic invertebrates collected from sites on $F$ ish Creek

\begin{tabular}{|c|c|c|c|c|c|c|}
\hline \multirow{2}{*}{ Site } & \multicolumn{2}{|c|}{$\mathrm{F}-1$} & \multicolumn{2}{|c|}{$F-2$} & \multicolumn{2}{|c|}{$\mathrm{F}-3$} \\
\hline & Mean & Range & Mean & Range & Mean & Range \\
\hline$F-1 \cdots \cdots$ & $-\cdots$ & $-\ldots$ & 0.64 & $0.48-0.78$ & 0.54 & $0.38-0.65$ \\
\hline$F-2 \cdots$ & 0.64 & $0.48-0.78$ & $\ldots$ & $\ldots$ & .67 & $.61-.71$ \\
\hline $\mathrm{F}-3-\cdots$ & .54 & $.38-.65$ & .67 & $.61-.71$ & --- & $---\cdots$ \\
\hline
\end{tabular}

Changes in the percentage composition of the major taxonomic groups between sampling dates are shown in figure 10. At site F-1, Diptera dominated during late fall and spring months, whereas Trichoptera dominated only in September 1980, and 01igochaeta in July 1981. The trend of Diptera dominance is prevalent at downstream sites as well. Trichoptera and Ephemeroptera were next in dominance at site F-2, and Trichoptera, Ephemeroptera, and 01igochaeta were next in dominance at site $\mathrm{F}-3$. However, it is clear that Diptera was the dominant group and comprised more than 50 percent of the composition on three sampling dates at site $\mathrm{F}-1$, on two dates at site $\mathrm{F}-2$, and on five dates at site $\mathrm{F}-3$. The high percentage of Diptera is due to large concentrations of midge larvae. 

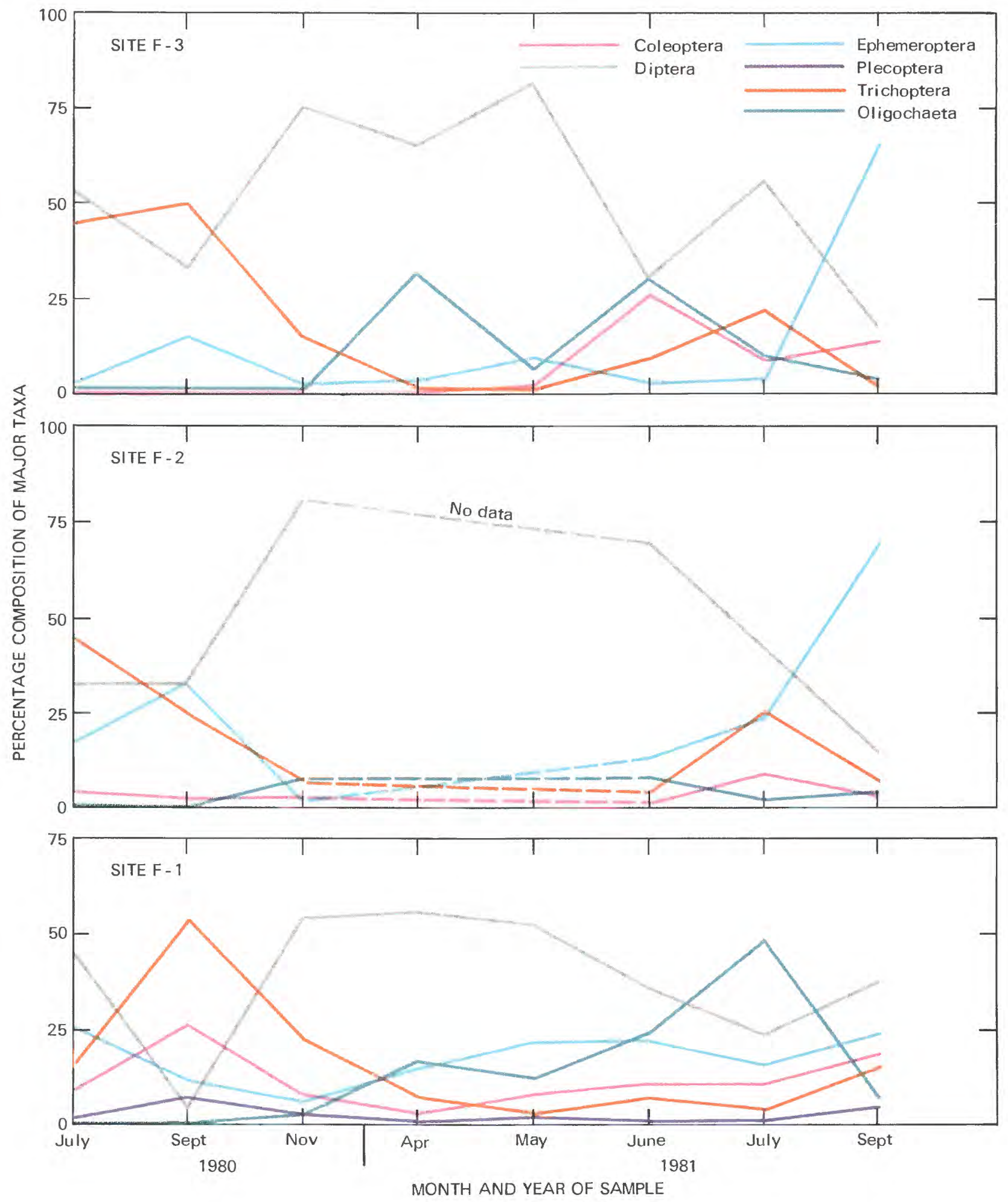

Figure 10.-- Percentage composition of major benthic invertebrate taxonomic groups collected from sites on Fish Creek. 
Organism densities per square meter at the Fish Creek sites are shown in figure 11. Density follows the trend of most Colorado streams where smallest concentrations of organisms generally occurred in late spring and early summer, and maximum concentrations occurred in late fall (November 1980) at all sites. The highest density $(51,000)$ was at site F-2 in November 1980 , and the lowest density $(1,000)$ occurred at site $\mathrm{F}-3$ in September 1981 . Mean density also was greatest at site $F-2(14,000)$ and least at site $F-3(10,000)$. Number of taxa generally decreased downstream with a mean of 33 taxa at site $\mathrm{F}-1,27$ at site $\mathrm{F}-2$, and 24 at site $\mathrm{F}-3$.

Species diversity was also used to quantify differences in the biological water quality of $\mathrm{Fish}$ Creek. Species diversity indices, including ranges and means for Fish Creek sites, are shown in table 13. There are apparent differences in species diversity between sites and diversity decreases downstream. This decrease coincides with increasing dominance of Diptera downstream indicating a less balanced environment, especially at site F-3.

Table 13.--species diversity indices for benthic invertebrates collected from sites on Fish Creek

\begin{tabular}{lccccc}
\hline & \multicolumn{5}{c}{ Diversity Index (d) } \\
\cline { 2 - 6 } Site & Mean & \multicolumn{4}{c}{ Range } \\
\cline { 2 - 6 } & & Minimum & (Date) & Maximum & (Date) \\
\hline F-1 & 3.43 & 2.89 & $(9-80)$ & 3.95 & $(9-81)$ \\
F-3-19-8 & 2.04 & $(9-81)$ & 3.44 & $(9-80)$ \\
& 2.92 & 2.40 & $(4-80)$ & 3.41 & $(5-81)$ \\
\hline
\end{tabular}

\section{Statistical Analyses}

Prior to statistical analyses, benthic invertebrate count data were tested for normality, and the results indicated a more normal distribution after transformation to the $\log$ base 10 . Therefore, all statistical analyses of benthic invertebrate densities were made on the transformed data at the 95-percent probability level. In addition, statistical tests for site F-2 are based on an unequal number of sampling dates.

An analysis of variance was run on the transformed densities to determine if there was a significant difference in densities between Fish Creek sites. Testing mean densities on individual sampling dates showed that there were significant differences between sites $\mathrm{F}-1$ and $\mathrm{F}-2$ in July and September 1980 and June and September 1981. The mean densities between sites $F-1$ and $F-3$ were significantly different for all sampling dates except November 1980, and there were no significant differences in mean densities between sites $F-2$ and F-3. However, summarizing results for all sampling dates showed no significant differences in mean densities between the three sites. 


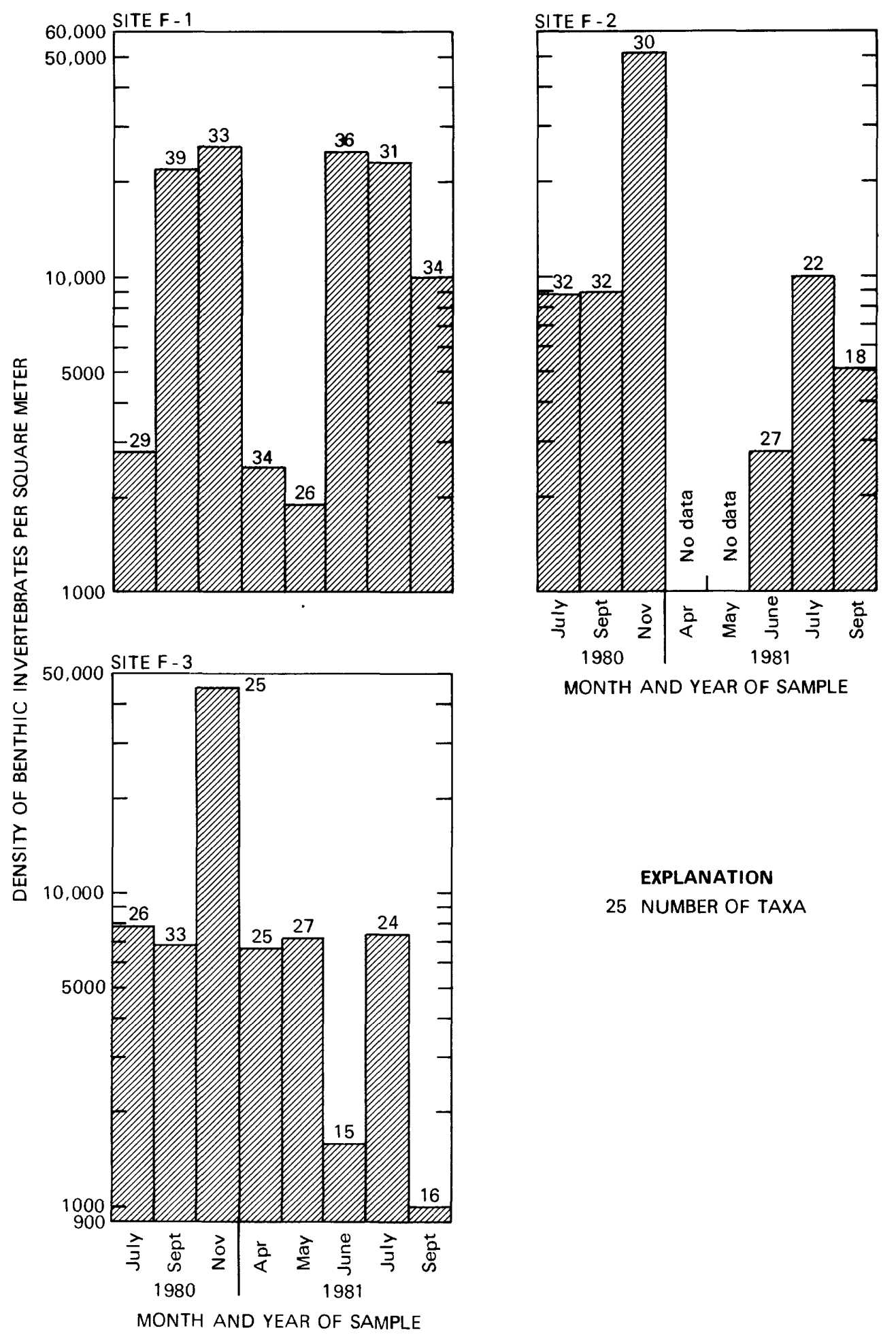

Figure 11.--Density of benthic invertebrates and taxa, per square meter, collected from sites on Fish Creek. 
Assessment of the trends in seasonal or sampling date differences showed significant differences in mean densities at all sites combined on certain sampling dates. For example, mean densities for Fish Creek sites on July and September 1980 and April, May, June, and July 1981 were not significantly different from each other; whereas mean densities for November 1980 and September 1981 were significantly different from each other. Highest mean densities were generally in November 1980 (fig. 11). Although there were significant differences in mean densities at the Fish Creek sites, these were accounted for by sampling date differences and not site differences.

A $t$-test was run on the densities of replicate samples collected at all sites on all dates. The only significant difference was for replicates sampled at site $\mathrm{F}-2$ in June 1981. In addition, there were no significant differences in mean number of taxa between replicate samples collected at the Fish Creek sites.

The analysis of variance procedure also showed that there was a significant difference in mean number of taxa between site $F-1$ and sites $F-2$ and $F-3$ but not between sites $\mathrm{F}-2$ and $\mathrm{F}-3$. The lowest mean number of taxa (24) was co.llected at site $F-3$, and highest mean number (33) at site F-1. In addition, about 45 percent of the variation in number of taxa was associated with the sites and about 55 percent of the variation in number of taxa was due to differences in sampling dates.

In summary, the analysis of variance and t-tests indicated significant variation in mean densities of benthic invertebrates between some sites and on most sampling dates. The analysis of variance test showed that about 50 percent of the variation in benthic invertebrate densities was due to sampling date (between and within site) differences, 34 percent to replicate sampling differences and sampling and analytical error, and about 16 percent of the variation can be explained by site differences.

The log-transformed benthic invertebrate densities were correlated with each measured water-quality constituent and property to determine if there was a significant relationship. At site $\mathrm{F}-1$, the best correlation, which was not significant, was density with specific conductance; the resulting r-value was 0.37. A better correlation of benthic invertebrate densities with water-quality data was obtained with a model using four independent variables (specific conductance, temperature, $\mathrm{pH}$, and dissolved oxygen) which resulted in an $r$-value (not significant) of 0.58 . The $r$-square value of 0.33 indicated that 33 percent of the variation in benthic invertebrate densities at site $\mathrm{F}-1$ was associated with these water-quality constituents.

At site $\mathrm{F}-2$, benthic invertebrate densities were significantly correlated with dissolved oxygen $(r=0.91)$, and water temperature $(r=-0.82)$. The mode 1 that gave the best correlation of density with water quality was again a model using four independent variables. The model included pH and specific conductance with the above-mentioned constituents. This correlation was highly significant $(p=0.0001)$, and the $r$-value was 1.0 . The determined $r$-square value of 1.0 indicated that 100 percent of the variation in benthic invertebrate densities was associated with the four water-quality constituents. 
Variation in densities associated with dissolved oxygen alone was about 83 percent. This association may occur because emergence of insects is influenced by water temperature which also affects the dissolved oxygen concentration. This strong correlation may also be a factor of small sample size and possibly because of an unequal number of samples.

At site $\mathrm{F}-3$ there was a significant correlation of benthic invertebrate densities with dissolved oxygen $(r=0.98)$. The stepwise modeling procedure indicated the four-variable model (adding $\mathrm{pH}$, water temperature, and specific conductance to dissolved oxygen) did not produce significant improvement in the correlation. An $r$-square value of 0.96 indicated that 96 percent of the variation in benthic invertebrate densities was associated with dissolved oxygen.

\section{Comparison with Other Studies}

A biological sampling program was conducted on Fish Creek on a near-quarterly basis from August 1979 to April 1981 by Harner-White Ecological Consultants, Inc. (1981). They sampled benthic invertebrates at two sites (similar to sites $\mathrm{F}-2$ and $\mathrm{F}-3$ in present study), using a Surber sampler having a 700- $\mu \mathrm{m}$ mesh size net. In 1980, Harner-White Ecological Consultants, Inc. (1981) found no significant difference $(p>0.01)$ in benthic invertebrate densities at the two sites. The results of the present study also indicated no significant differences in the densities $(p>0.05)$ between sites $F-2$ and $\mathrm{F}-3$. Mean densities were 23,000 organisms at site F-2 and 20,000 organisms at site F-3 during the present study (1980 sampling dates). Mean densities were much lower for the Harner-White Ecological Consultants, Inc. (1981) study. This is probably because the smaller $(210-\mu \mathrm{m})$ mesh size net used in the present study allowed for collection of the smaller aquatic insects. However, mean number of taxa collected at site $F-2$ was similar in both studies, but Harner-White Ecological Consultants, Inc. (1981) collected more at site F-3.

Seasonal trends in density were similar in the two studies. In both studies, lowest densities at both sites generally were found in the early summer months (June or July). These low densities reflected the effects of scour from spring runoff in a soft substrate stream like Fish Creek. At site $\mathrm{F}-2$, in the Harner-White Ecological Consultants, Inc. (1981) study, largest densities occurred in the August sample, but at site F-3 the greatest densities occurred in the fall (October). In the present study, the greatest densities occurred in the fall (November).

For 1980 sampling, Harner-White Ecological Consultants, Inc. (1981) showed an increase in percentage of caddisfly and stonefly densities, but a decrease in percentage of Diptera or true-fly densities from site F-2 to F-3. In the present study, there was a slight increase in percentage of Diptera but also an increase in percentage of caddisfly and stonefly densities between the two sites. However, the same organisms were dominant in the two studies.

Diversity indices calculated for the 1980 samples of the present study were a little less at each site than in the Harner-White Ecological Consultants, Inc. (1981) study. However, a similar decrease occurred in diversityindex values from site $\mathrm{F}-2$ to $\mathrm{F}-3$. 
Data collected by Harner-White Ecological Consultants, Inc. (1981) in 1979 and 1981 showed increasing benthic invertebrate densities between sites $\mathrm{F}-2$ and F-3. However, for 1981 the present study showed decreasing densities downstream. However, both 1979 and 1981 results were similar to results of the 1981 sampling of the present study which showed increasing Diptera densities downstream. As in the present study, the increases were due to higher densities of chironomids.

In general, results from the two studies were similar especially with respect to taxonomic composition. Basically, densities of Diptera and Ephemeroptera (mostly collector-type organisms) increased downstream. Although Trichoptera varied seasonally, the percentage was similar at the two sites. Percentages of Plecoptera and Coleoptera were similar for both studies, and neither group (except Coleoptera at site F-2) was an important contributor to the faunal density. Results, however, including densities and percentage composition of taxonomic groups were more variable both seasonally and by site in the Harner-White Ecological Consultants, Inc. (1981) study than in the present study.

Harner-White Ecological Consultants, Inc. (1981) concluded that differences in the biological communities of $\mathrm{Fish}$ Creek were insignificant and highly variable and that the benthic invertebrate communities were similar at both sites.

\section{Williams Fork}

\section{Physical and Chemical Water Quality}

Water-quality field measurements and discharge data for the Williams Fork are in Britton (1983). A summary showing mean (median for $\mathrm{pH}$ ) and ranges of these water-quality measurements is in table 14.

Table 14.--Summary of water-quality constituents and properties measured from sites on the Williams Fork

$\left[{ }^{\circ} \mathrm{C}\right.$, degree Celsius; umho, micromhos per centimeter at $25^{\circ} \mathrm{C}$; $\mathrm{mg} / \mathrm{L}$, milligrams per liter]

\begin{tabular}{lrrrrrrrr}
\hline Site & $\begin{array}{c}\text { Water } \\
\text { temperature } \\
\left({ }^{\circ} \mathrm{C}\right)\end{array}$ & \multicolumn{2}{c}{$\begin{array}{c}\text { Specific } \\
\text { conductance } \\
(\mu \mathrm{mho})\end{array}$} & \multicolumn{2}{c}{$\begin{array}{c}\mathrm{pH} \\
(\text { units })\end{array}$} & $\begin{array}{c}\text { Dissolved } \\
\text { oxygen } \\
(\mathrm{mg} / \mathrm{L})\end{array}$ \\
\cline { 2 - 9 } & Mean & Range & Mean & Range & Median & Range & Mean & Range \\
\hline WF-1-- & 11.8 & $0.0-21.5$ & 264 & $205-540$ & 8.1 & $7.8-8.7$ & 8.2 & $6.1-8.2$ \\
WF-2-- & 13.5 & $.5-25.1$ & 491 & $268-587$ & 8.0 & $7.8-8.7$ & 8.0 & $5.8-10.7$ \\
WF-3-- & 13.8 & $.2-24.0$ & 453 & $269-622$ & 7.9 & $7.2-8.5$ & 8.4 & $7.2-11.0$ \\
WF-4-- & 13.5 & $.4-24.1$ & 497 & $277-689$ & 7.9 & $7.7-8.8$ & 8.1 & $6.7-10.4$ \\
\hline
\end{tabular}


The only difference between sites in water quality was a slight increase in specific conductance downstream. This is a normal condition in most streams and is a result of the simple accumulation of soluble salts. Dissolved oxygen concentrations were reduced at the sites during the periods of warmest water temperature. The lowest concentration of dissolved oxygen was 5.8 milligrams per liter measured at site WF-2. On about one-half of the sampling dates and at all sites, the dissolved oxygen was less than saturation concentrations. At site WF-2, six out of eight measured dissolved oxygen concentrations were undersaturated. These concentrations may be even less during the night because of uptake from respiring plants and animals.

A size classification of bed material collected from the Williams Fork is in table 3 . The results show a slight decrease in the larger material downstream on the main stem. In conjunction with this decrease, there is a slight increase in the finer material downstream at site WF-4. The classification technique does not assess the proportion of larger (greater than gravel size) material, but upon observation site WF-4 has about 50 percent less larger material than sites WF-1 or WF-3. Bed material at site WF-3 is composed mainly of large boulders washed down from the valley canyon upstream. For this reason, WF- 3 was the most difficult site to sample because there were no small riffle sections.

\section{Benthic Invertebrate Composition and Occurrence}

There were 85 taxa identified at site WF-1, 79 at site WF-2, 75 at site WF-3, and 77 at site WF-4 (Britton, 1983). The decrease in number of taxa downstream was primarily because of decreases in Coleoptera, Diptera, and Trichoptera. Ranges and means of the percentage composition of the major taxonomic groups at each site are shown in figure 12. The percentage composition of Diptera and Coleoptera generally decreased downstream whereas the percentage composition of Trichoptera and Ephemeroptera generally increased. On all sampling dates the five orders of aquatic insects (Coleoptera, Diptera, Ephemeroptera, Plecoptera, and Trichoptera) comprised well over 90 percent of the mean density of organisms.

At site WF-1, a beetle (optioservus castanipennis) was the most abundant and frequently collected organism, followed by a Chironomid (Chironomidae Form 1) and a mayfly (Baetis bicaudatis). Chironomidae Form 1 was dominant at site WF-2, followed by a caddisfly (Hydropsyche) and a beetle (Optioservus castanipennis). Another caddisfly (Cheumatopsyche) dominated at site WF-3, followed by two mayflies, Baetis bicaudatis and Tricorythodes. Baetis bicaudatis dominated at site WF-4, followed by the two caddisflies, Hydropsyche and Cheumatopsyche.

Along with changes in the species composition of the benthic invertebrates, there were also subtle differences in the functional groups of the Williams Fork community. The relative abundance of benthic invertebrate functional groups is shown for all Williams Fork sites in table 15. Collector-type organisms, comprised mainly of mayflies and caddisflies, were the dominant functional group at all sites, and there was only a slight increase in total percentages downstream. Shredders were more numerous at 


\section{EXPLANATION}

7.9-36.9 RANGES IN PERCENTAGE COMPOSITION FOR ALL SAMPLING DATES
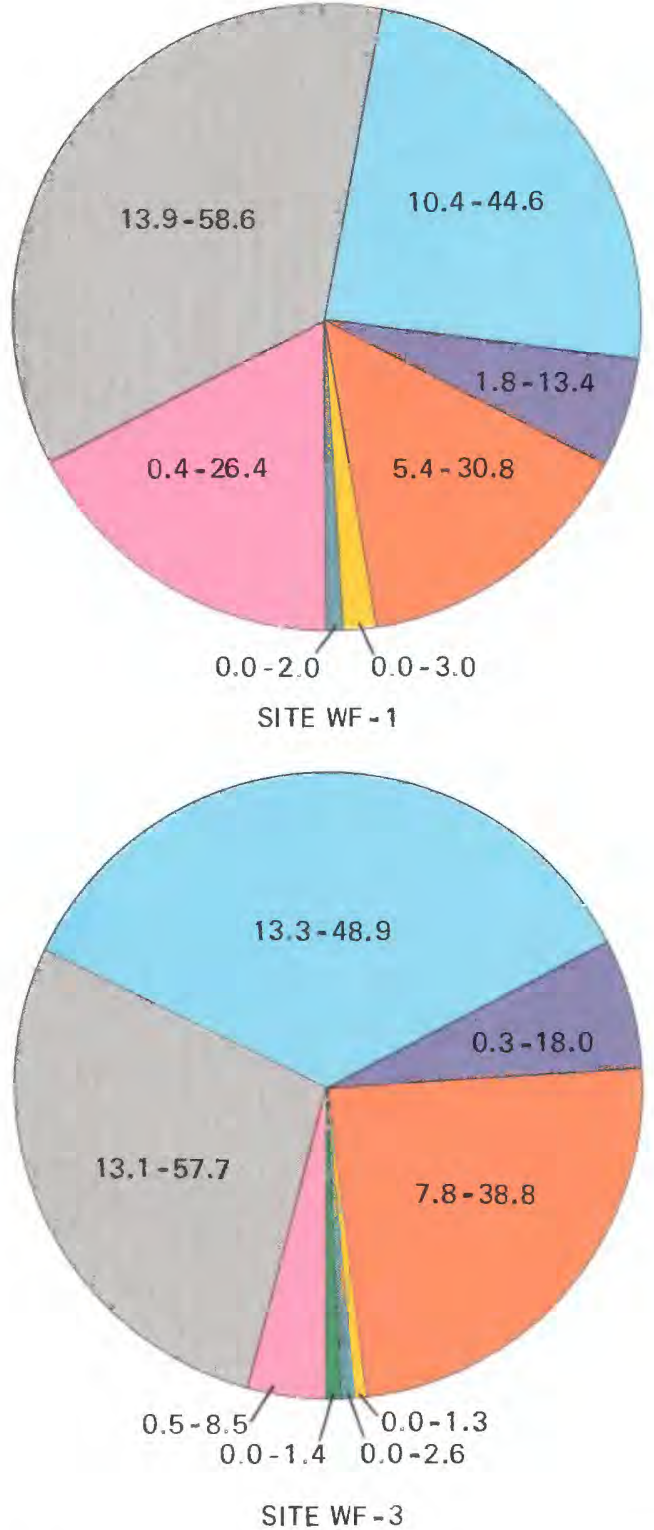
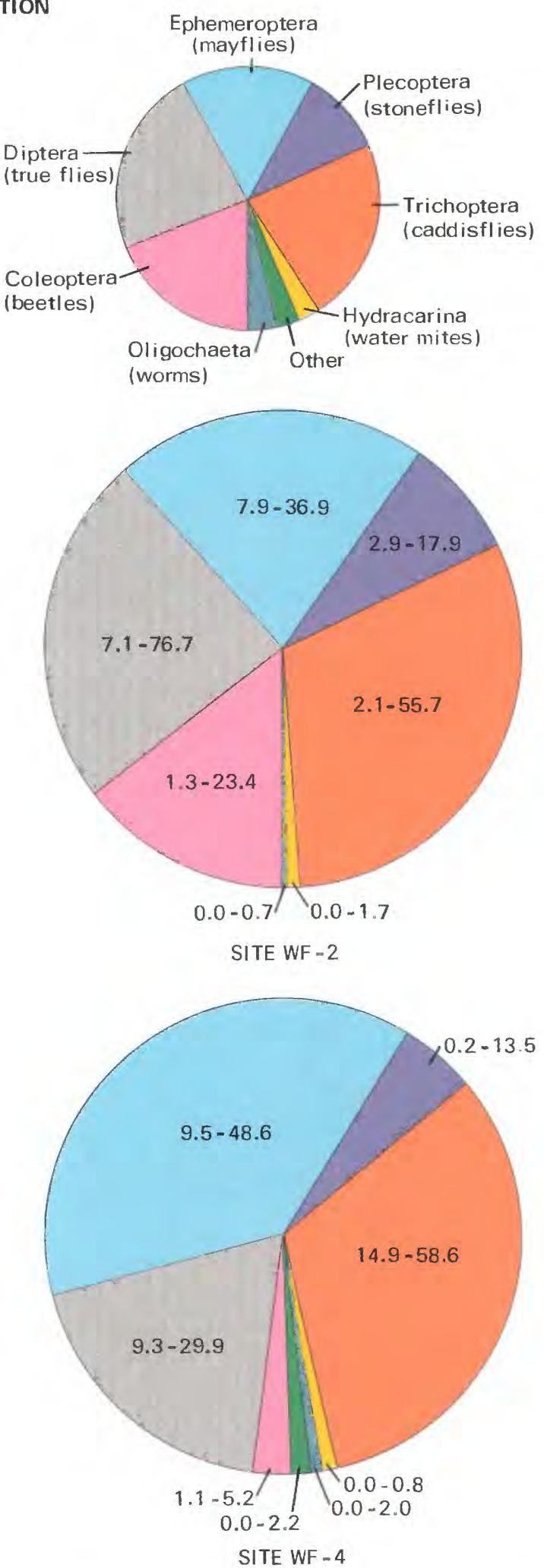

Figure 12.-- Mean percentage composition of major benthic invertebrate taxonomic groups collected from sites on the Williams Fork for all sampling dates. 
site WF-1 because a greater canopy or cover resulted in greater concentrations of leaf litter. Grazers are adapted to an environment in which they can scrape periphyton and other plant material from rocks and other surfaces. This algal growth, although not measured, seemed to be more extensive at sites WF-2 and WF-4. These growths should be investigated, especially because there is evidence of unsaturated dissolved oxygen conditions at site WF- 2 . Cattle grazing and hay production in meadows adjacent to this site may provide nutrients favorable for algal growth.

Table 15.--Relative abundance of benthic invertebrate functional groups collected from sites on the Williams Fork

\begin{tabular}{|c|c|c|c|c|}
\hline \multirow{2}{*}{ Functional group } & \multicolumn{4}{|c|}{ Percentage of total } \\
\hline & $W F-1$ & WF-2 & WF -3 & $W F-4$ \\
\hline $\begin{array}{l}\text { Shredders } \\
\text { Grazers } \\
\text { Col lectors-gatherers } \\
\text { Col lectors-filterers } \\
\text { Predators- }\end{array}$ & $\begin{array}{r}14 \\
17 \\
50 \\
8 \\
11\end{array}$ & $\begin{array}{r}4 \\
18 \\
33 \\
36 \\
9\end{array}$ & $\begin{array}{r}8 \\
6 \\
48 \\
29 \\
9\end{array}$ & $\begin{array}{r}3 \\
14 \\
44 \\
29 \\
10\end{array}$ \\
\hline Total- & 100 & 100 & 100 & 100 \\
\hline
\end{tabular}

The taxa present at each site were compared using the index of percentage similarity. Mean and ranges in similarity indices for the Williams Fork sites are shown in table 16. Sites WF-3 and WF-4 have the most similar taxa, largely because they are physically nearest each other. Sites WF-1 and WF-4 have the least similar taxa probably as a result of physical differences in habitat. Generally, the September 1980 samples had the greatest similarity and June 1981 samples were the least similar.

Table 16.--Similarity indices for benthic invertebrates collected from sites on the williams Fork

\begin{tabular}{|c|c|c|c|c|c|c|c|c|}
\hline \multirow{2}{*}{ Site } & \multicolumn{2}{|c|}{$W F-1$} & \multicolumn{2}{|c|}{$W F-2$} & \multicolumn{2}{|c|}{$W F-3$} & \multicolumn{2}{|c|}{$W F-4$} \\
\hline & Mean & Range & Mean & Range & Mean & Range & Mean & Range \\
\hline WF-1-- & --- & $-\cdots$ & 0.70 & $0.56-0.80$ & 0.63 & $0.55-0.73$ & 0.61 & $0.56-0.72$ \\
\hline WF-2-- & 0.70 & $0.56-0.80$ & --- & --- & .72 & $.58-.86$ & .67 & $.56-.80$ \\
\hline WF-3-- & .63 & $.55-.73$ & .72 & $.58-.86$ & $-\cdots$ & $-\cdots-$ & .78 & $.72-.86$ \\
\hline$W F-4--$ & .61 & $.56-.72$ & .67 & $.56-.80$ & .78 & $.72-.86$ & $-\cdots$ & ---- \\
\hline
\end{tabular}


Changes in the percentage composition of major taxonomic groups between sampling dates are shown in figure 13. At site WF-1, Diptera dominates during the spring and summer months but decreases in the fall and is replaced by Coleoptera, Ephemeroptera, and Trichoptera. At site WF-2, Diptera was dominant only during April 1981, whereas Coleoptera, Ephemeroptera, and Trichoptera dominated the composition on all other sampling dates. The same is true for site WF-3, except that Coleoptera decreased and Diptera were dominant in July 1980. Diptera were never dominant at site WF-4; but again, Trichoptera and Ephemeroptera were the co-dominant orders.

Benthic invertebrate densities per square meter at the Williams Fork sites, along with number of taxa collected on each sampling date, are shown in figure 14. Densities are lower in late spring and early summer and greater in summer and fall when larvae hatch from summer-laid eggs. Basically, peaks in density were in November 1980 and July 1981. The densities for all sites were extremely similar and exhibited two definite peaks and two definite declines. The highest density $(18,000)$ was collected at site WF-2 in July 1981; but site WF-4 had the highest mean density $(7,700)$, whereas, site WF-1 had the lowest mean density of 5,400 organisms per square meter. Site WF-4 had gravel-riffle beds suitable for sampling, whereas site WF-3 was a wide site subject to high flows and velocities, and had large boulders and little access to grave1-riffle habitats suitable for Surber sampling. Except for site WF-3, densities were slightly higher downstream, whereas number of taxa generally decreased downstream from a mean high of 38 taxa at site WF-1 to 32 taxa at site WF-3. However, site WF-4 had a mean of 35 taxa.

Species diversity was again used to quantify differences in the biological water quality of the Williams Fork. Mean and ranges of species diversity for all sites and sampling dates are shown in table 17. The species diversity reflected the stability of the benthic invertebrate communities with a mean high of 3.84 at site WF-1 and a low of 3.46 at site WF-2.

Table 17.--species diversity indices for benthic invertebrates collected from sites on the Williams Fork

Diversity Index (d)

\begin{tabular}{|c|c|c|c|c|c|}
\hline \multirow{3}{*}{ Site } & & & & & \\
\hline & \multirow{2}{*}{ Mean } & \multicolumn{4}{|c|}{ Range } \\
\hline & & Minimum & (Date) & Maximum & (Date) \\
\hline WF-1 $-\ldots \ldots$ & 3.84 & 3.24 & $(4-81)$ & 4.20 & $(9-81)$ \\
\hline WF-2 $\cdots \cdots \cdots$ & 3.46 & 2.34 & $(4-81)$ & 3.95 & $(6-81)$ \\
\hline WF-3- & 3.54 & 2.83 & $(7-80)$ & 3.89 & $(9-81)$ \\
\hline WF-4 & 3.62 & 2.29 & $(7-80)$ & 4.16 & $(11-80)$ \\
\hline
\end{tabular}




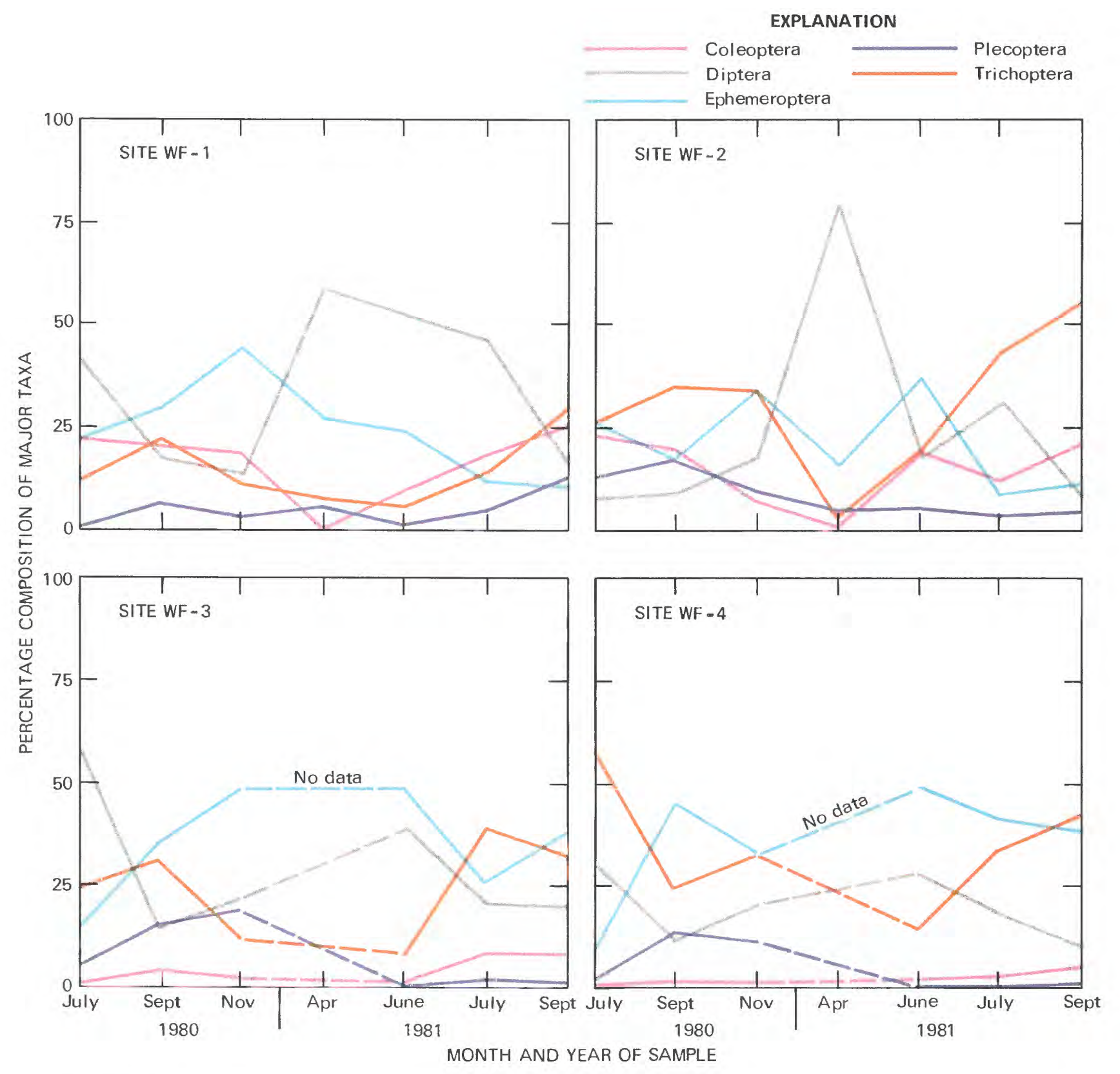

Figure 13.-- Percentage composition of major benthic invertebrate taxonomic groups collected from sites on the Williams Fork. 

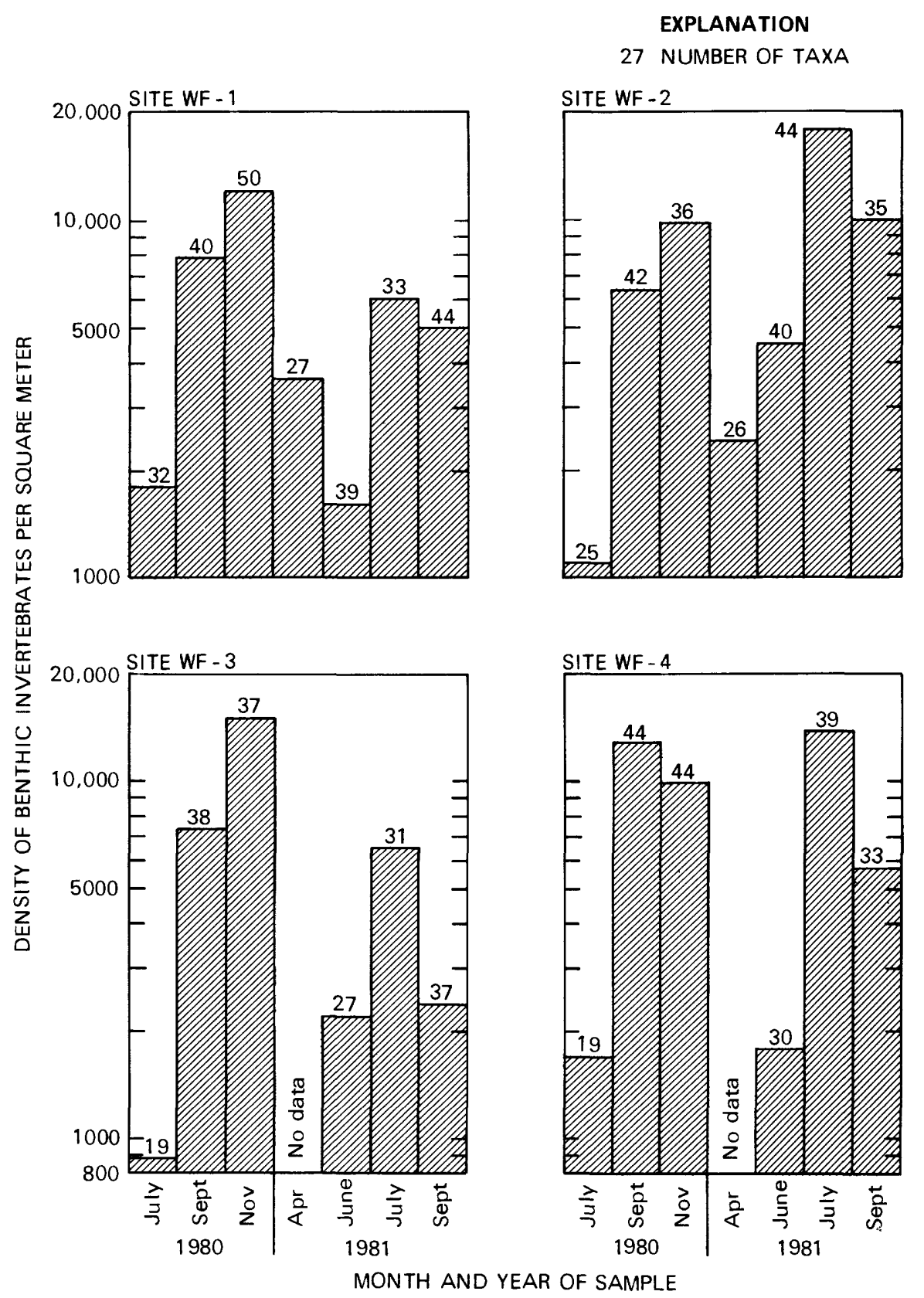

Figure 14.-- Density of benthic invertebrates and taxa, per square meter, collected from sites on the Williams Fork. 


\section{Statistical Analyses}

The benthic invertebrate data collected from the Williams Fork were tested for normality, and densities were less skewed after transformation to the $\log$ base 10 . Therefore, all statistical testing of benthic invertebrate densities was conducted on the transformed data.

An analysis of variance was run on the transformed counts to determine if there was a significant difference in counts among the four sites. Testing the mean densities on individual dates showed that there were significant differences in densities between sites WF-1 and WF- 2 on all dates except November 1980; between WF-1 and WF-3 on all dates except September 1980 and July 1981; between WF-1 and WF-4 on all dates except November 1980 and June 1981; between WF-2 and WF-3 on all dates except July and September 1980; between WF- 2 and WF-4 on all dates except November 1980; and between WF- 3 and WF-4 on all dates except June 1981. Statistical results for all dates showed that mean densities for sites WF-1 and WF-3 were not significantly different from each other, but mean densities for site WF-3 were significantly different from those for site WF-4. Mean densities for site WF-3 were also significantly different from WF-2, but WF-1 and WF-2 were not significantly different. The results are summarized as follows: mean densities having the same letter are not significantly different.

\begin{tabular}{lllll} 
Site & Log of Mean Counts & & \multicolumn{2}{c}{ Grouping } \\
\cline { 2 - 3 } WF-1 & 2.575718 & & A & B \\
WF-2 & 2.670374 & & A & \\
WF-3 & 2.518174 & & B \\
WF-4 & 2.688340 & A &
\end{tabular}

Assessment of trends in seasonal or sampling date differences showed significant differences in mean densities for all sites combined between most sampling dates. The largest significant difference was between the November and July 1980 samples. The smallest difference, which was not statistically significant, was between November 1980 and July 1981 samples.

A t-test was run on mean densities of benthic invertebrates in replicate samples from all sites and on all dates. At site WF-1 there was a significant difference in benthic invertebrate densities in replicate samples collected in September 1981. There were no other significant differences in benthic invertebrate densities in replicate samples collected at other sites or on other sampling dates.

The analysis of variance model also showed that there was no significant difference in mean number of taxa among the Williams Fork sites. The highest mean number of taxa (38) was collected at site WF-1, and the lowest mean number of taxa (31) was at site WF-3. In addition, the results showed that 95 percent of the variation in mean number of taxa was due to sampling date and 5 percent was due to site differences.

In summary, the analysis of variance and $t$-test results indicated variations in mean densities of benthic invertebrates, especially for different dates. The analysis of variance procedure showed that 68 percent of the 
variation in mean densities of benthic invertebrates was due to sampling date differences, both between and within sites, and about 20 percent was due to variations in replicate samples, and sampling and analytical error. The remaining 12 percent of the variation in mean densities was due to differences between the sites.

The log-transformed densities were correlated with each measured water-quality constituent to determine if there was a significant relationship. At site WF-1, there was a significant correlation of benthic invertebrate densities with dissolved oxygen $(r=0.79)$. The best correlation was a two-variable model including dissolved oxygen and $\mathrm{pH}$ which resulted in a significant $r$-value of 0.91 . The $r$-square value of 0.83 indicated that 83 percent of the variation in benthic invertebrate densities was associated with dissolved oxygen and $\mathrm{pH}$.

At site WF-2, $\mathrm{pH}$ had the best correlation with benthic invertebrate densities $(r=0.73)$, but was not significant. Adding the other three water-quality constituents and properties to the model increased the maximum $r$-square improvement from 0.53 to 0.59 . Therefore, 53 percent of the variation in benthic invertebrate densities can be associated with $\mathrm{pH}$ alone as compared to 59 percent for all four water-quality constituents combined.

At site WF-3, dissolved oxygen provided the best correlation with benthic invertebrate densities $(r=0.82)$, but was not significant. The best correlation was a four-variable model using dissolved oxygen, water temperature, $\mathrm{pH}$, and specific conductance which resulted in an r-value of 1.0 . Therefore, 100 percent of the variation in benthic invertebrate densities could be associated with these four water-quality variables. This strong correlation may be a factor of small sample size.

At site WF-4, no single water-quality constituent tested was significantly correlated with benthic invertebrate densities. The best model for correlation with densities used $\mathrm{pH}$, dissolved oxygen, and specific conductance which resulted in an r-value of 0.99 . Therefore, 99 percent of the variation in densities could be associated with these three water-quality constituents.

\section{Canadian River}

\section{Physical and Chemical Water Quality}

Water-quality field measurements and discharge data for the Canadian River are in Britton (1983). A summary showing means (median for $\mathrm{pH}$ ) and ranges of these water-quality measurements is in table 18.

Specific conductance provided the greatest difference in water quality between the two Canadian River sites. Generally, specific conductance was more than three times greater at site $C R-2$ than at site $C R-1$. The increase was probably due to the greater agricultural development downstream including grazing, hay production, and irrigation as well as normal accumulation of soluble salts from runoff. Water temperature and $\mathrm{pH}$ also increased slightly downstream at site CR-2. 
Table 18.--Summary of water-quality constituents and properties measured from sites on the Canadian River

$\left[{ }^{\circ} \mathrm{C}\right.$, degree Celsius; $\mu$ mho, micromhos per centimeter at $25^{\circ} \mathrm{C}$; $\mathrm{mg} / \mathrm{L}$, milligrams per liter]

\begin{tabular}{|c|c|c|c|c|c|c|c|c|}
\hline \multirow[t]{2}{*}{ Site } & \multicolumn{2}{|c|}{$\begin{array}{c}\text { Water } \\
\text { temperature } \\
\left({ }^{\circ} \mathrm{C}\right)\end{array}$} & \multicolumn{2}{|c|}{$\begin{array}{c}\text { Specific } \\
\text { conductance } \\
(\mu \mathrm{mho})\end{array}$} & \multicolumn{2}{|c|}{$\begin{array}{c}\mathrm{pH} \\
\text { (units) }\end{array}$} & \multicolumn{2}{|c|}{$\begin{array}{c}\text { Dissolved } \\
\text { oxygen } \\
(\mathrm{mg} / \mathrm{L})\end{array}$} \\
\hline & Mean & Range & Mean & Range & Median & Range & Mean & Range \\
\hline $\begin{array}{l}\text { CR-1-- } \\
\text { CR-2-- }\end{array}$ & $\begin{array}{r}9.9 \\
13.3\end{array}$ & $\begin{array}{r}0.0-20.0 \\
.0-22.2\end{array}$ & $\begin{array}{r}78 \\
287\end{array}$ & $\begin{array}{r}30-120 \\
216-373\end{array}$ & $\begin{array}{l}7.3 \\
7.7\end{array}$ & $\begin{array}{l}6.6-8.0 \\
7.5-8.6\end{array}$ & $\begin{array}{l}8.6 \\
8.1\end{array}$ & $\begin{array}{l}6.7-11.8 \\
6.9-10.3\end{array}$ \\
\hline
\end{tabular}

Although dissolved oxygen concentrations decreased downstream because of higher water temperatures, the water at both sites was nearly always saturated or supersaturated with dissolved oxygen. Previous studies conducted on North Park streams (Scherschligt, 1975; Britton, 1979) found unsaturated dissolved oxygen conditions which are primarily due to low stream gradient.

A size classification of bed material samples collected from the Canadian River sites is in table 4. The results showed a higher percentage of grave1size material at site CR-1 ( 89 percent) than at site CR-2 (66 percent). The percentage of sand and silt was consequently three times higher at the downstream site (CR-2). The amount of larger material decreases downstream probably because of reduced slope. The sediment load for the 1980 water year at site CR-2 was 3,367 tons compared to 522 tons at site CR-1 (U.S. Geological Survey, 1981).

\section{Benthic Invertebrate Composition and Occurrence}

There were 67 taxa identified at site CR-1 and 69 taxa at site CR-2 (Britton, 1983). Greater numbers of Diptera and Coleoptera taxa were collected at the downstream site $(C R-2)$, but at this site there were fewer Ephemeroptera and Trichoptera taxa. Ranges and means of the percentage composition of the major taxonomic groups at each site are in figure 15. The percentage of Diptera increased markedly at the downstream site (CR-2) from a mean of 26 percent at site CR-1 to 49 percent at CR-2. In contrast with this increase, almost all other major groups except Ephemeroptera decreased downstream. For example, Trichoptera decreased from a mean of 19 percent at site $\mathrm{CR}-1$ to 3 percent at site $\mathrm{CR}-2$, and Plecoptera decreased from 21 percent at CR-1 to 3.5 percent at site CR-2.

On all sampling dates at site $\mathrm{CR}-1$ and all sampling dates except June and July 1981 at site CR-2, the five orders of aquatic insects (Coleoptera, Diptera, Ephemeroptera, Plecoptera, and Trichoptera) comprised well over 90 percent of the mean density. 


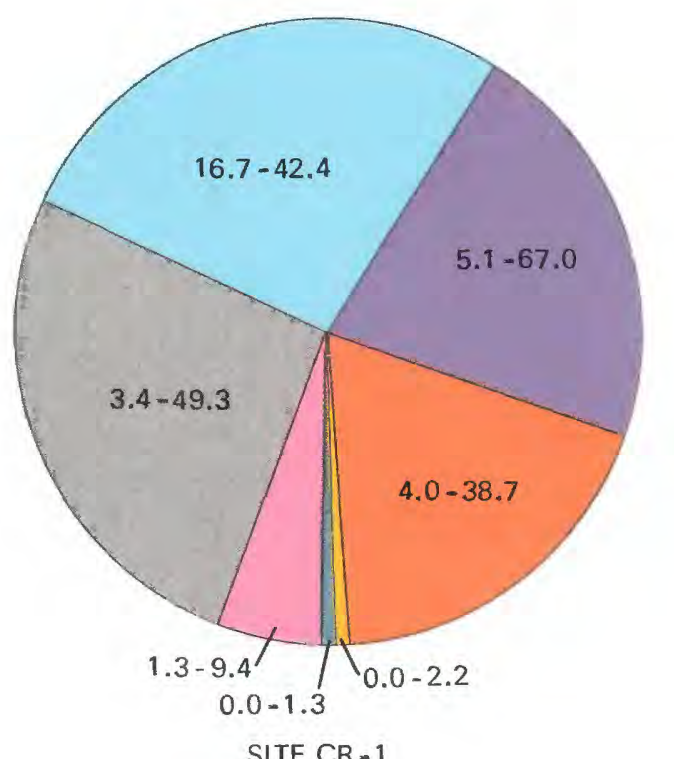

\section{EXPLANATION}

1.3-9.4 RANGES IN PERCENTAGE COMPOSITION FOR ALL SAMPLING DATES
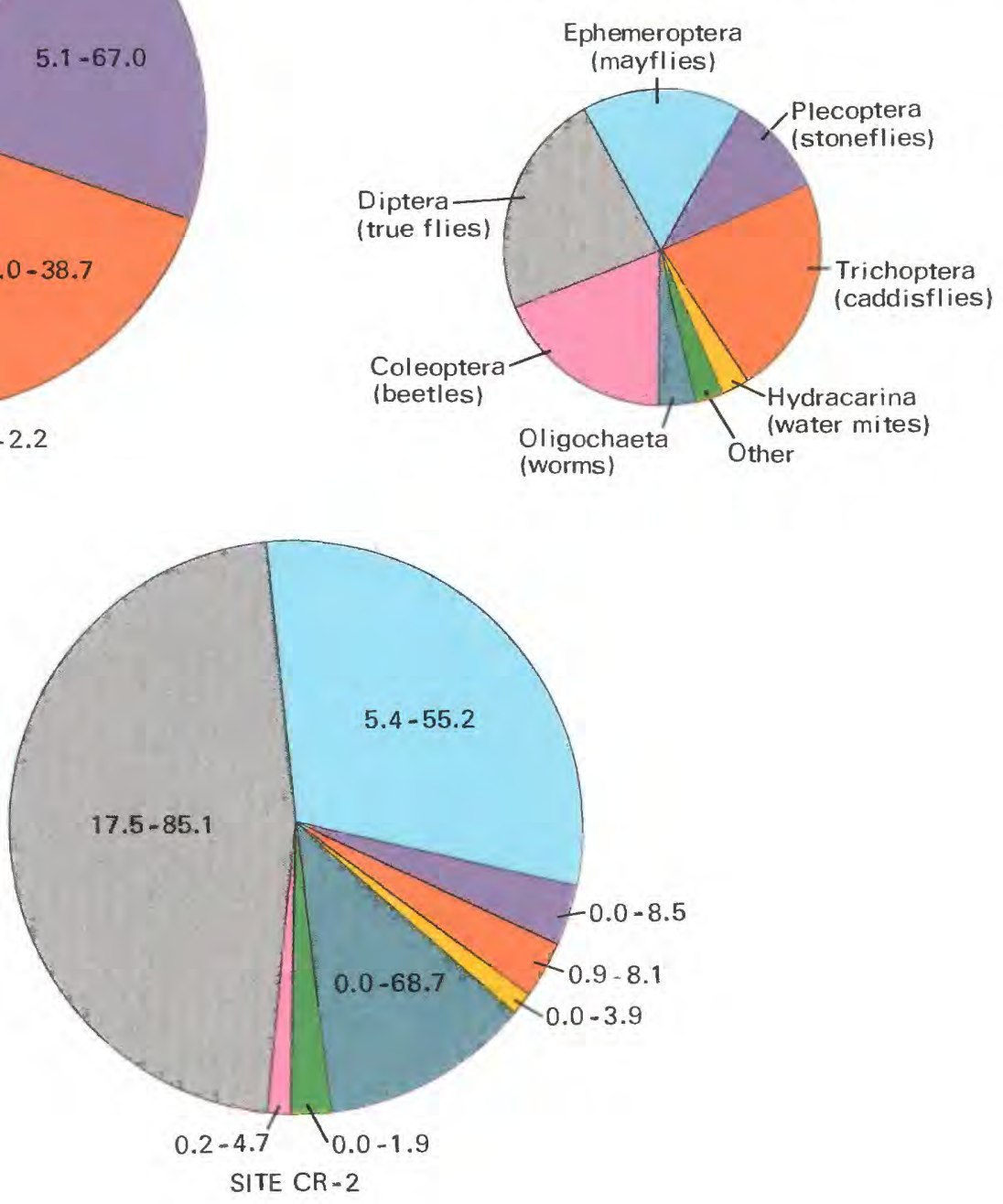

Figure 15.-- Mean percentage composition of major benthic invertebrate taxonomic groups collected from sites on the Canadian River for all sampling dates. 
Stoneflies of the family Chloroperlidae were the most abundant (mean = 1,400 organisms per square meter) and frequently collected organisms at site CR-1, followed by caddisflies (Hydropsyche) and mayflies (Baetis bicaudatis). Chironomid larvae, which had a mean density of 2,600 organisms per square meter, were the most frequently collected organisms at site CR-2, followed by mayflies (Tricorythodes). Limnodrilus of the class 0ligochaeta had the greatest mean density at site CR-2 of 2,700 organisms per square meter but was not collected as frequently.

Not only were there differences in the species or taxonomic composition between sites, but there were also differences in functional aspects of the Canadian River community. Relative abundance of functional groups in the Canadian River is given in table 19. The most obvious trend was the increased percentage of collector-gatherers at site CR-2. Collector-gatherers were more abundant at the downstream site because the river changes to a more open lowland system downstream, and the organisms rely on a food base of organic detritus imported from upstream. This high percentage of collector-gatherer type organisms indicates that the reach between sites $C R-1$ and $C R-2$ has a high enough primary productivity base to support a benthic community that is dependent on the supply of autochthonous (in stream) produced materials such as algae. For example, the increase in the 0ligochaeta group (11,000 organisms per square meter) collected in June at site CR-2 probably occurred as a result of inputs of fine particulate organic material derived from several sources, including shredder feces as a result of high spring runoff.

Table 19.--Relative abundance of benthic invertebrate functional groups collected from sites on the Canadian River

\begin{tabular}{|c|c|c|}
\hline \multirow{2}{*}{ Functional group } & \multicolumn{2}{|c|}{ Percentage of total } \\
\hline & $C R-1$ & $\mathrm{CR}-2$ \\
\hline $\begin{array}{l}\text { Shredders } \\
\text { Grazers } \\
\text { Col lectors-gatherers } \\
\text { Collectors-filterers } \\
\text { Predators }\end{array}$ & $\begin{array}{r}7 \\
8 \\
39 \\
23 \\
23\end{array}$ & $\begin{array}{r}7 \\
<1 \\
77 \\
12 \\
3\end{array}$ \\
\hline Total & 100 & 100 \\
\hline
\end{tabular}

Taxa at the two sites were compared using an index of percentage similarity. The similarity indices at the two Canadian River sites for all sampling dates are in table 20. Similarity indices range from 0.32 to 0.68 indicating that the two sites do not have very similar taxa. However, these streams are a great distance apart (about $20 \mathrm{miles}$ ), and the indices are only a little less than those furthest upstream and downstream sites on other stream reaches in this study. 
Table 20.--Similarity indices for benthic invertebrates collected from sites on the Canadian River

\begin{tabular}{ccccccccc}
\hline \multirow{2}{*}{$\begin{array}{c}\text { Sites } \\
\text { compared }\end{array}$} & \multicolumn{6}{c}{ Similarity indices } & \multirow{5}{*}{ Mean } \\
\cline { 2 - 7 } & $7 / 80$ & $9 / 80$ & $11 / 80$ & $4 / 81$ & $6 / 81$ & $7 / 81$ & $9 / 81$ \\
\hline CR-1 - CR-2-- & 0.32 & 0.56 & 0.48 & 0.68 & 0.57 & 0.52 & 0.51 & 0.52 \\
\hline
\end{tabular}

Changes in percentage composition of the major taxonomic groups between sampling dates are in figure 16. At site CR-1, a11 major groups except for Coleoptera dominate the composition on at least one sampling date. Typically, Diptera colonized and reproduced in the spring (April 1981) but decreased in percentage composition during the summer as Trichoptera and Plecoptera increased. The trend in percentage composition is different at site CR-2. Diptera dominated the composition on four of seven sampling dates, and as at site CR-1, had the highest percentage again in April. The percentage of Ephemeroptera decreased throughout the fall of 1980, reestablished itself again in June 1981, and increased slightly throughout the summer. The reason for the high percentage of 07 igochaeta in the June 1981 sample is unknown but may be due to incidences of high flows (introducing organic food material), shifting bed material from heavy spring rains, or simply a life history phenomenon.

Density and number of taxa per square meter collected at the Canadian River sites on each sampling date are in figure 17 . The trend in density at site CR-1 is fairly typical of Colorado streams; highest densities are in late summer and fall due to egg hatching in the summer, and lowest densities of organisms are in late spring due to emergence of adults and scour from spring runoff. The pattern at site CR-2 in 1980 is similar, but there were increasing densities from spring to throughout the summer. Generally, the densities increased at site CR-2; the mean at site CR-2 for all sampling dates was 9,900 organisms per square meter, while the mean at site CR-1 was about 6,800 organisms per square meter. The mean number of taxa at site CR-2 (27 taxa per square meter) was less than at site $C^{-1}$ (31 taxa per square meter).

Species diversity was used as a tool to quantify differences in the biological water quality of the Canadian River. Mean and ranges of species diversity indices for the Canadian River sites are in table 21. The species diversity index verified the changes in percentage composition between the two sites with a decrease from a mean of 3.45 at site $C R-1$ to 2.75 at site CR-2. 


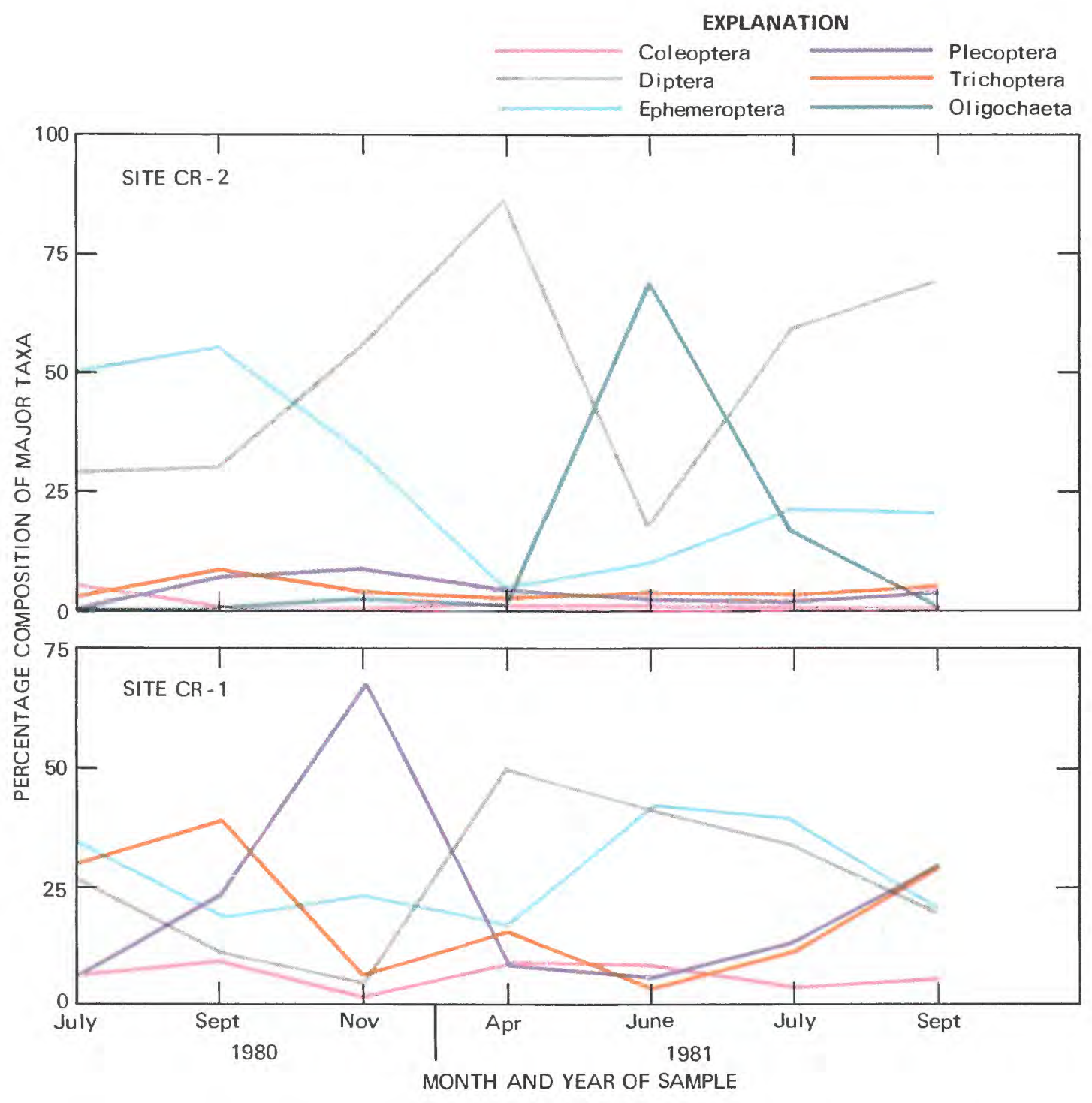

Figure 16.--Percentage composition of major benthic invertebrate taxonomic groups collected from sites on the Canadian River. 


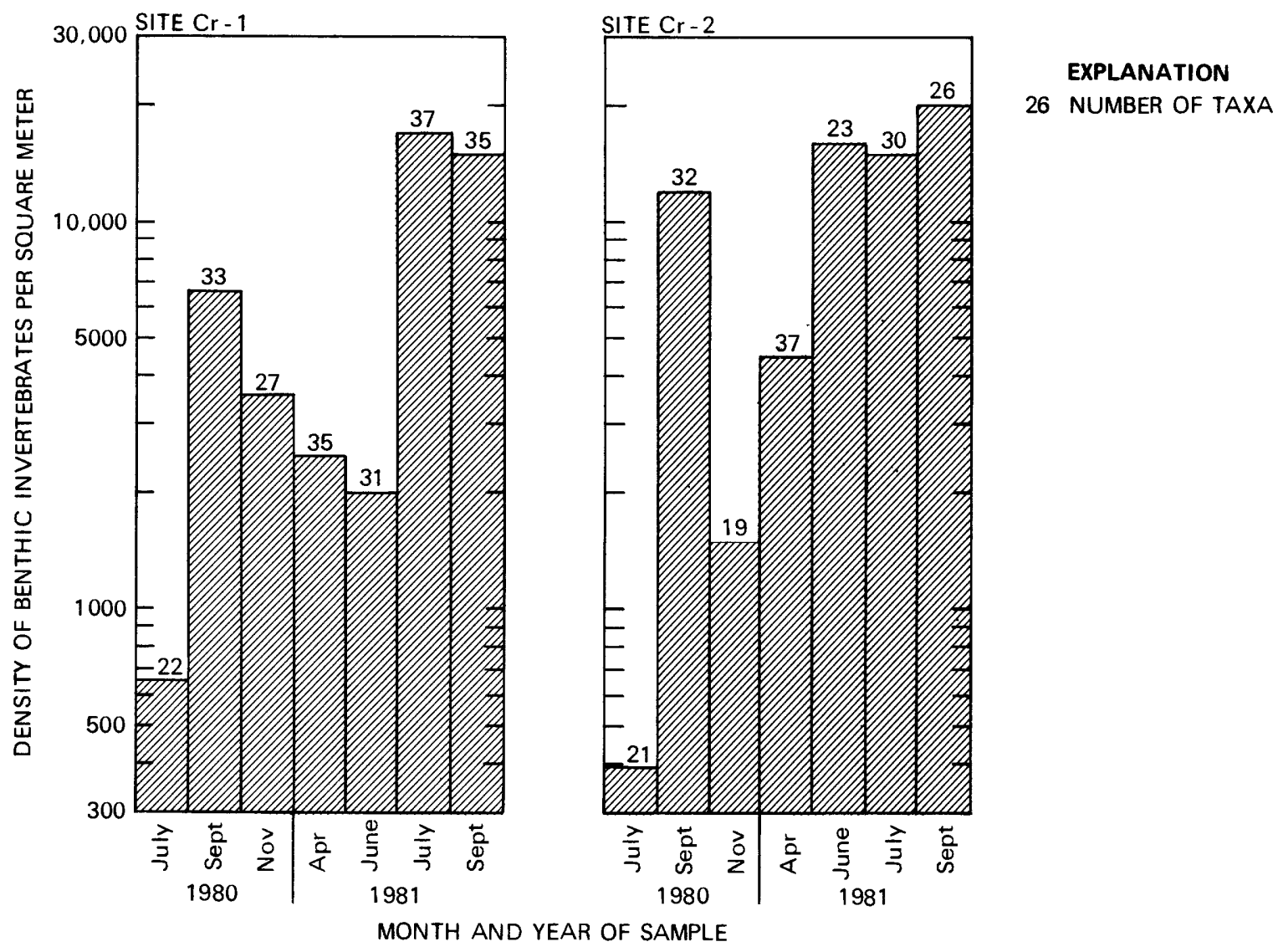

Figure 17.--Density of benthic invertebrates and taxa, per square meter, collected from sites on the Canadian River. 
Table 21.--species diversity indices for benthic invertebrates collected from sites on the Canadian River

\begin{tabular}{cccccc}
\hline & \multicolumn{5}{c}{ Diversity Index (d) } \\
\cline { 2 - 6 } Site & Mean & \multicolumn{4}{c}{ Range } \\
\cline { 2 - 6 } & & Minimum & (Date) & Maximum & (Date) \\
\hline CR-1-18 & & $(11-80)$ & 4.22 & $(4-81)$ \\
CR-2-10 & & 3.63 & $(7-80)$ \\
\hline
\end{tabular}

\section{Statistical Analyses}

The benthic invertebrate data collected from the Canadian River were tested using several statistical analysis techniques. The data were analyzed for normality, and densities were less skewed after transformation to the log base 10 . Therefore, all statistical testing of benthic invertebrate densities was conducted on the transformed data.

An analysis of variance was run on the benthic invertebrate densities to determine if there was a significant difference between the two sites. Overal1, mean densities for all dates were not significantly different between the sites. A comparison of combined mean densities on al1 dates and at both sites showed that July and November 1980 densities were significantly less than those on all other sampling dates. The mean densities on the remaining sampling dates, however, were not significantly different from each other.

A t-test was run on densities collected in replicate samples for all sampling dates at both Canadian River sites. A comparison of all replicates within each site showed there were no significant differences in mean densities in replicate samples at either Canadian River site.

The analysis of variance procedure also showed that there was no significant difference in mean number of taxa between the Canadian River sites. In addition, results showed that 90 percent of the variation in number of taxa was due to sampling date differences, and 10 percent was due to site differences.

In summary, the analysis of variance test showed that there was not a significant difference in mean densities between sites, but there were differences between sampling dates both between and within sites. The analysis of variance procedure showed that about 10 percent of the variation in mean densities was due to differences between sites, and about 78 percent of the variation was due to sampling date differences between and within sites. The remaining 12 percent of the variation in mean densities was due to replication and sampling and analytical error. 
The benthic invertebrate densities were correlated with each measured water-quality constituent to determine if there was a significant relationship. At site CR-1, mean densities did not significantly correlate with the tested water-quality constituents. The best model fit was obtained using a four-variable model that correlated mean densities with $\mathrm{pH}$, water temperature, specific conductance, and dissolved oxygen. The correlation, which was significant, resulted in an $r$-square value of 0.57 indicating that 57 percent of the variation in mean densities at site $C R-1$ was associated with these four water-quality constituents.

At site CR-2, mean densities did not significantly correlate with the tested water-quality constituents. A four variable model resulted in an $r$-square value of 0.38 which indicated that about 38 percent of the variation in densities at site CR-2 was associated with the four water-quality constituents.

\section{Little Grizzly and Grizzly Creeks}

Physical and Chemical Water Quality

Water-quality field measurements and discharge data for Little Grizzly and Grizzly Creeks are in Britton (1983). A summary showing means (median for $\mathrm{pH})$ and ranges of these water-quality measurements is in table 22.

Table 22.--summary of water-quality constituents and properties measured from sites on Little Grizzly and Grizzly Creeks

$\left[{ }^{\circ} \mathrm{C}\right.$, degree Celsius; $\mu$ mho, micromhos per centimeter at $25^{\circ} \mathrm{C}$; $\mathrm{mg} / \mathrm{L}$, milligrams per liter]

\begin{tabular}{lrrrrrrrc}
\hline Site & $\begin{array}{c}\text { Water } \\
\text { temperature } \\
\left({ }^{\circ} \mathrm{C}\right)\end{array}$ & $\begin{array}{c}\text { Specific } \\
\text { conductance } \\
(\mu \mathrm{mho})\end{array}$ & $\begin{array}{c}\mathrm{pH} \\
(\text { units })\end{array}$ & $\begin{array}{c}\text { Dissolved } \\
\text { oxygen } \\
(\mathrm{mg} / \mathrm{L})\end{array}$ \\
\cline { 2 - 9 } & Mean & Range & Mean & Range & Median & Range & Mean & Range \\
\hline LGr-1- & 9.2 & $0.0-20.0$ & 60 & $21-100$ & 7.3 & $6.4-7.6$ & 8.3 & $6.6-10.4$ \\
LGr-2- & 11.7 & $.3-21.3$ & 220 & $160-282$ & 7.5 & $7.1-8.9$ & 8.3 & $6.7-11.7$ \\
Gr-1-- & 12.3 & $.2-18.8$ & 216 & $154-286$ & 7.5 & $7.3-8.1$ & 7.0 & $5.2-10.4$ \\
\hline
\end{tabular}

Major differences in water quality between sites were in the specific conductance and dissolved oxygen. Specific conductance was more than threefold higher at sites $L G r-2$ and $G r-1$ than at site $L G r-1$. The upstream site was a control site having generally pristine forested conditions upstream. Agricultural activities such as grazing, hay production, and irrigation are major land uses downstream to site $\mathrm{Gr}-1$. These activities tend to contribute (by way of runoff) soluble salts to the stream; concentrations, however, would be considered low. Dissolved oxygen was saturated or supersaturated on at least 
50 percent of the sampling dates at sites $L G r-1$ and LGr-2. However, dissolved oxygen was unsaturated at site Gr-1 on all sampling dates. A diel study of dissolved oxygen concentrations at different seasonal water temperatures would be required to determine the duration of low dissolved oxygen concentrations at this site.

Bed material size classification at these sites is in table 5 . This table does not completely describe the substrate characteristics at these sites. Site LGr-1 is in a typical small, upper woodland-type stream having a variety of larger fist-sized cobbles mixed with gravel and sand. The amount of larger material decreases markedly downstream as Little Grizzly and Grizzly Creeks enter a wide, flat valley having little slope. At site Gr-1 there is virtually no substrate material larger than small cobbles, and only one riffle area has a gravel-mixture bottom.

\section{Benthic Invertebrate Composition and Occurrence}

There were 87 taxa collected and identified at site LGr-1, 80 at LGr-2, and 59 at site Gr-1 (Britton, 1983). The decrease in number of taxa downstream was due to decreases in number of taxa from every major group except Diptera. Ranges and means of percentage composition of major taxonomic groups for each site are in figure 18. The percentage of Diptera increased markedly downstream from a mean of 25 percent at site LGr-1 to 70 percent at site Gr-1. There was a marked decrease in Coleoptera and increases in Ephemeroptera, Diptera, and Trichoptera downstream.

On almost all sampling dates the five orders of aquatic insects (Coleoptera, Diptera, Ephemeroptera, Plecoptera, and Trichoptera) comprised more than 90 percent of the mean density. Two beetles (Optioservus castanipennis and Zaitzevia parvula) were the most frequently occurring and abundant organisms collected at site LGr-1. Hydropsyche, a caddisfly, was the next most dominant organism. A mayfly (Tricorythodes) was the most dominant organism at site LGr-2, followed by Chironomidae Form 1 and a caddisfly (Hydropsyche). At site Gr-1, three chironomids (Chironomidae Form 1, Chironomidae Form 7, and Chironomidae Form 5) were the more numerous and frequently collected organisms.

Not only were there differences in taxonomic composition between sites, but there also were some differences in the functional aspects of the benthic invertebrate communities. Relative abundance of the functional groups at Little Grizzly and Grizzly Creek sites is in table 23. 


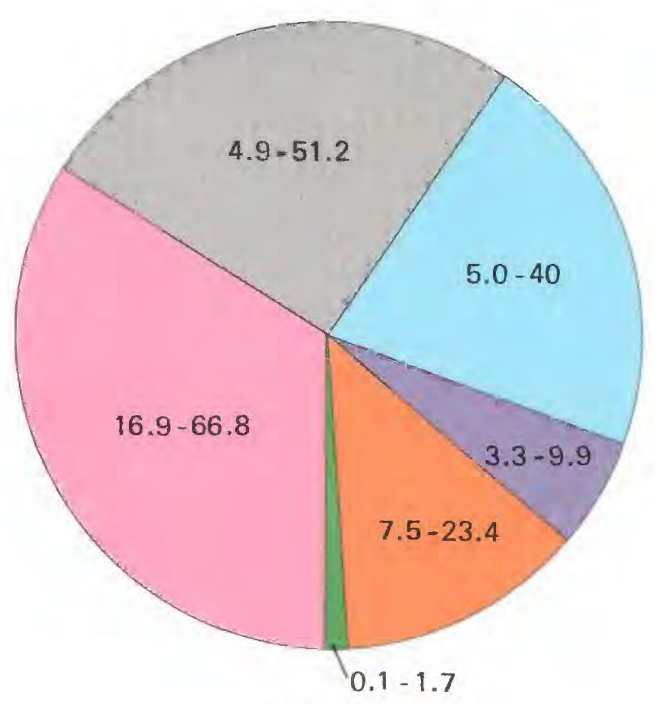

SITE LGr-1

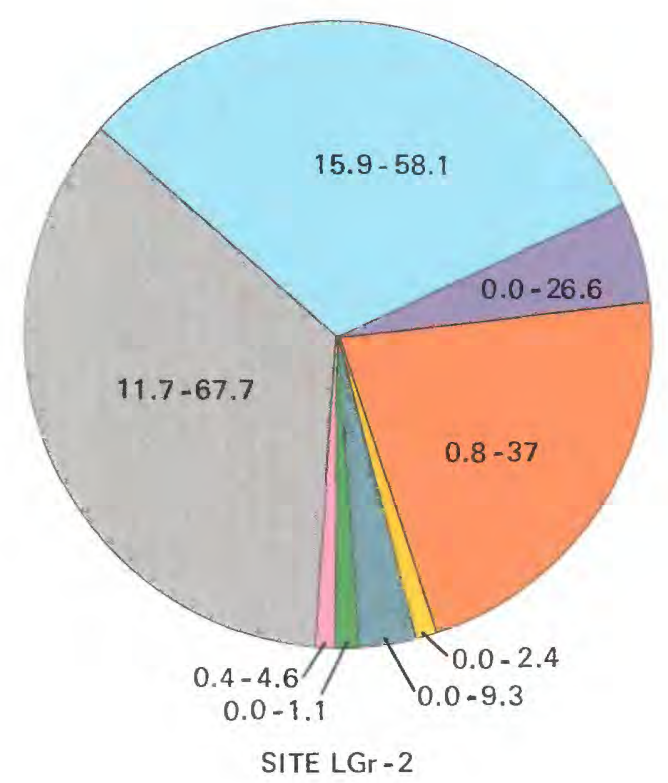

EXPLANATION

4.9-51.2 RANGES IN PERCENTAGE COMPOSITION FOR ALL SAMPLING DATES
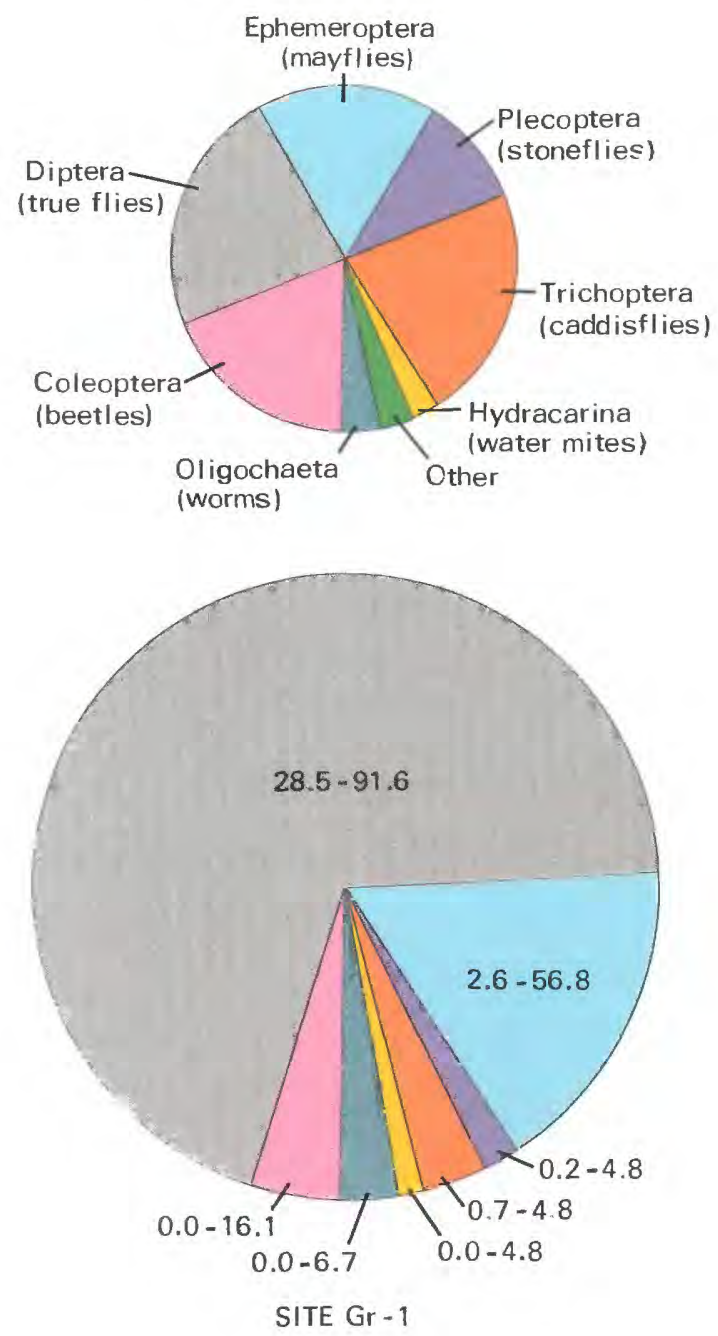

Figure 18.--Mean percentage composition of major benthic invertebrate taxonomic groups collected from sites on Little Grizzly and Grizzly Creeks for all sampling dates. 
Table 23.--Relative abundance of benthic invertebrate functional groups collected from sites on Little Grizzly and Grizzly Creeks

\begin{tabular}{lccc}
\hline \multirow{2}{*}{ Functional group } & \multicolumn{3}{c}{ Percentage of total } \\
\cline { 2 - 4 } & LGr-1 & LGr-2 & Gr-1 \\
\hline Shredders- & 6 & 5 & $<1$ \\
Grazers- & 33 & 4 & 5 \\
Collectors-gatherers- & 43 & 32 & 24 \\
Collectors-filterers- & 7 & 13 \\
Predators-- & 7 & 100 & 100 \\
\hline
\end{tabular}

Differences in the functional structure of the benthic invertebrate communities can be related to minor differences in environmental conditions. The obvious difference is the decrease in grazers downstream from site LGr-1 and the subsequent increases in the collector-type feeding groups. Grazers, such as beetles and caddisflies, become less important at the downstream sites mainly because of changes in flow and substrate. These organisms have morpho-behavioral adaptations for scraping periphyton from exposed surfaces in rapidly flowing, turbulent water. The flow conditions change downstream to a much slower and less turbulent pattern because of reduced slope. Sites LGr-2 and $\mathrm{Gr}-1$ are thus more suitable to organisms that collect and filter organic materials that accumulate from upstream. The result is an increase in Diptera adapted to slower moving water, less available oxygen, and a food base of fine organic detrital materials.

Taxa were compared between sites using an index of percentage similarity. Mean and ranges in similarity indices among the Grizzly Creek sites are in table 24. Sites LGr-2 and Gr-1 have the most similar taxa whereas sites LGr-1 and $\mathrm{Gr}^{-1}$ have the least similar taxa. This is a result partly of sites LGr-2 and $\mathrm{Gr}-1$ being physically nearest to each other and sites LGr-1 and Gr-1 being the furthest apart. Greatest similarities were found on various sampling dates, but the similarity indices for all sites were the least for September 1981.

Changes in percentage composition of the major taxonomic groups between sampling dates are in figure 19. At site $L G r-1$, Diptera dominated especially in the April and June samples, but Coleoptera and Ephemeroptera were dominant on the other sampling dates. At site LGr-2, Diptera dominated again during April and June, but Ephemeroptera and Trichoptera dominated the rest of the time. At site $\mathrm{Gr}-1$, Diptera dominated on every sampling date (comprising as much as 92 percent in Apri1), except during July 1980 when Ephemeroptera comprised the greatest percentage. 
Table 24.--Similarity indices for benthic invertebrates collected from sites on Little Grizzly and Grizzly Creeks

\begin{tabular}{|c|c|c|c|c|c|c|}
\hline \multirow{2}{*}{ Site } & \multicolumn{2}{|c|}{ LGr-1 } & \multicolumn{2}{|c|}{ LGr-2 } & \multicolumn{2}{|c|}{$\mathrm{Gr}-1$} \\
\hline & Mean & Range & Mean & Range & Mean & Range \\
\hline LGr-1---- & ---- & --- & 0.54 & $0.47-0.72$ & 0.47 & $0.36-0.58$ \\
\hline LGr-2-- - - - & 0.54 & $0.47-0.72$ & --- & ---- & .60 & $.46-.69$ \\
\hline $\mathrm{Gr}-1-\cdots-\cdots$ & .47 & $.36-.58$ & .60 & $.46-.69$ & $-\cdots$ & ---- \\
\hline
\end{tabular}

Densities per square meter at Little Grizzly and Grizzly Greek sites, along with number of taxa collected on each sampling date, are in figure 20 . Site LGr-2 had the greatest mean density of organisms $(8,800$ per square meter). Site LGr-1 had a mean density of 6,400 organisms, and $\mathrm{Gr}-1$ had a mean density of 2,400 organisms. Site $L G r-1$ had the greatest mean number of taxa (35 per square meter), whereas, there were 30 at site LGr-2 and 24 at site $\mathrm{Gr}-1$.

Species diversity was used as a statistical tool to quantify differences in the biological water quality of the Grizzly Creek sites. Mean and ranges in species diversity indices are shown in table 25. Diversity decreased downstream because percentage composition changed from a varied taxonomic fauna at site LGr-1 to a fauna consisting primarily of Diptera at site Gr-1. Actually, one would expect to see an even greater difference in diversity indices between sites $\mathrm{LGr}^{-1}$ and $\mathrm{Gr}-1$, but there were enough Diptera taxa to maintain a relatively high diversity index at site $\mathrm{Gr}-1$.

\section{Statistical Analyses}

Benthic invertebrate densities were tested using several statistical analysis techniques. The data were analyzed for normality, and the Little Grizzly and Grizzly Creek benthic invertebrate densities were found to be less skewed after transformation to the $\log$ base 10 . Therefore, all statistical testing of benthic invertebrate densities was conducted on the transformed data. 

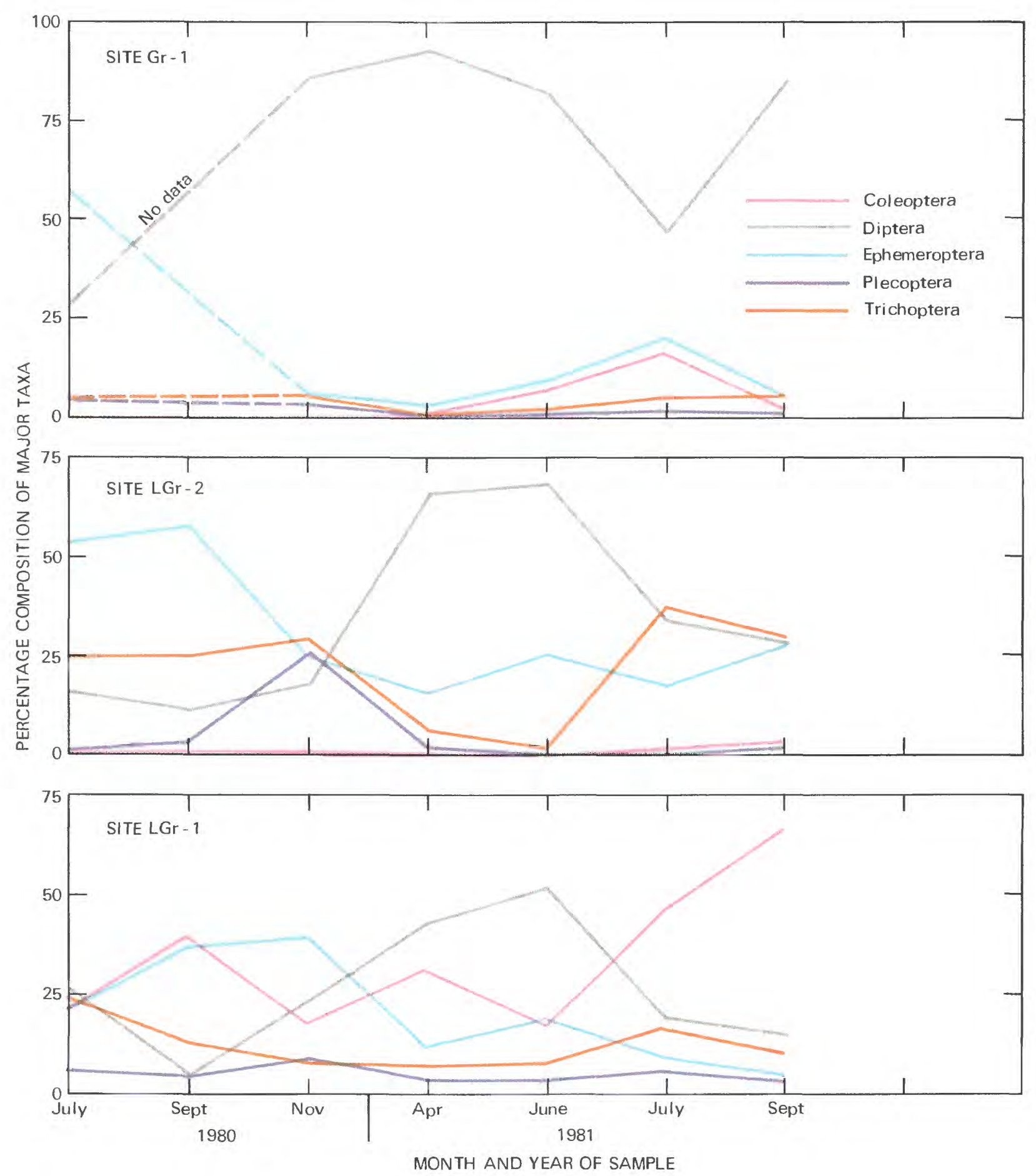

Figure 19.--Percentage composition of major benthic invertebrate taxonomic groups collected from sites on Little Grizzly and Grizzly Creeks. 

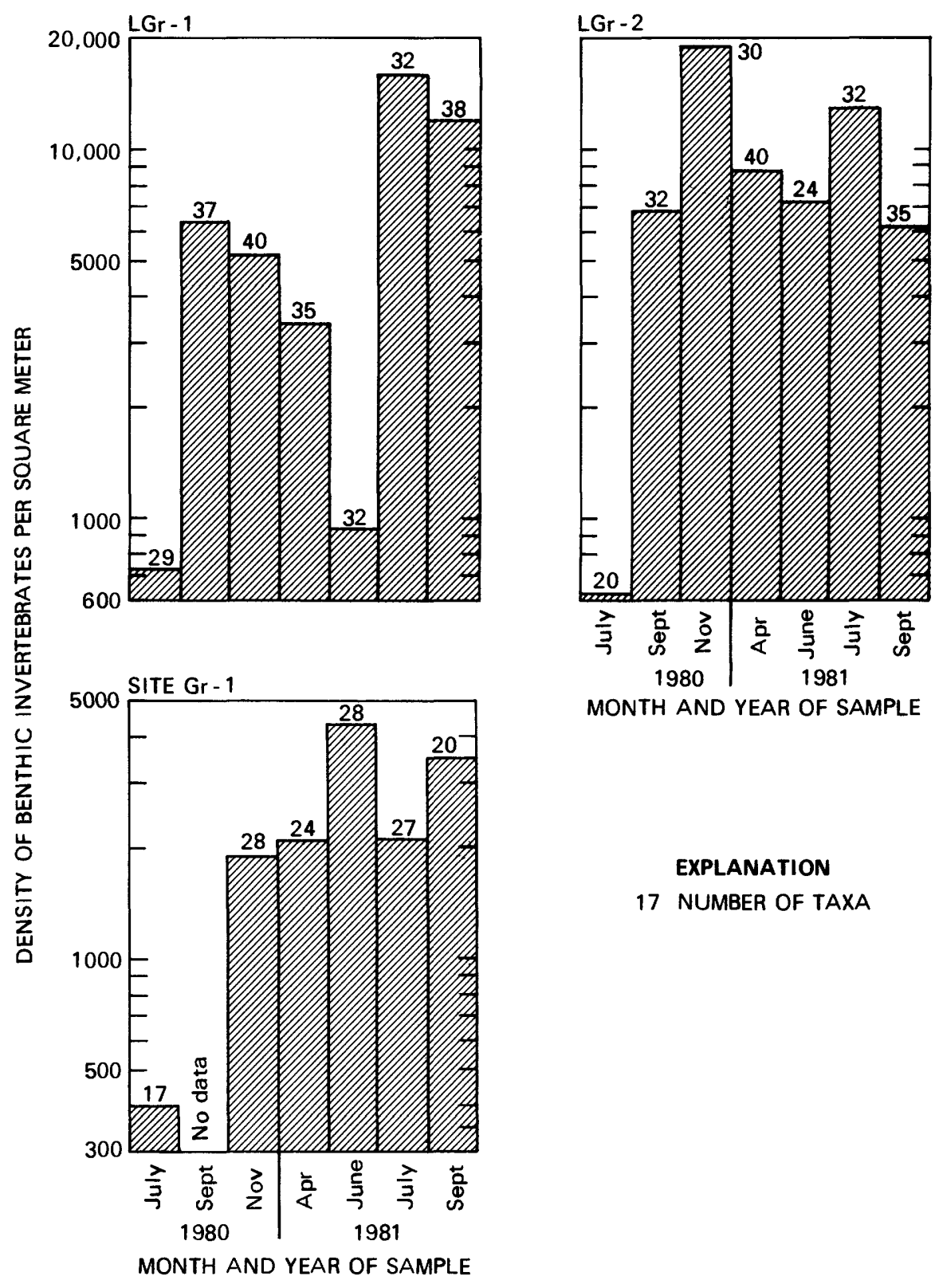

MONTH AND YEAR OF SAMPLE

EXPLANATION

17 NUMBER OF TAXA

Figure 20..-Density of benthic invertebrates and taxa, per square meter, collected from sites on the Little Grizzly and Grizzly Creeks. 
Table 25.--species diversity indices for benthic invertebrates collected from sites on Little Grizzly and Grizzly Creeks

\begin{tabular}{|c|c|c|c|c|c|}
\hline \multirow{3}{*}{ Site } & \multicolumn{5}{|c|}{ Diversity Index (d) } \\
\hline & \multirow{2}{*}{ Mean } & \multicolumn{4}{|c|}{ Range } \\
\hline & & Minimum & (Date) & Maximum & (Date) \\
\hline 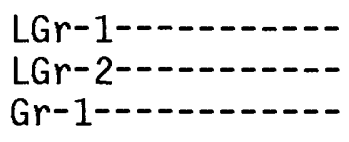 & $\begin{array}{l}3.67 \\
3.15 \\
2.97\end{array}$ & $\begin{array}{l}2.90 \\
2.42 \\
2.40\end{array}$ & $\begin{array}{l}(9-81) \\
(6-81) \\
(9-81)\end{array}$ & $\begin{array}{l}4.17 \\
3.55 \\
3.66\end{array}$ & $\begin{array}{r}(6-81) \\
(11-80) \\
(7-81)\end{array}$ \\
\hline
\end{tabular}

An analysis of variance was run on the mean densities to determine if there was a significant difference in mean densities among the three sites. Testing the mean densities for individual dates showed that there were significant differences between sites $L G r-1$ and $L G r-2$ on all sampling dates except July and September 1980. The mean densities between sites $\mathrm{LGr}-1$ and $\mathrm{Gr}-1$ were significantly different on all sampling dates except September 1981. Finally, the mean densities between sites $L G r-2$ and $G r-1$ were significantly different on all sampling dates except July 1980. Summarizing, the statistical results for all dates showed that the mean densities were significantly lower at site $\mathrm{Gr}-1$ as compared to sites $\mathrm{LGr}-1$ and $\mathrm{LGr}-2$.

An assessment of the trends of seasonal or sampling date differences showed significant differences in mean densities within and between sites for sampling dates. The highest mean densities for all sites combined were found in July 1981 and the lowest mean densities in July 1980.

A $t$-test was run on the densities collected in replicate samples for all sites and sampling dates. There were no significant differences in mean densities in replicate samples collected at any time or at any site.

The analysis of variance procedure also showed that there was a significant difference in mean number of taxa between the Grizzly Creek site (Gr-1) and the Little Grizzly Creek sites (LGr-1 and LGr-2). In addition, 47 percent of the variation in number of taxa was due to site differences and 53 percent was due to sampling date differences.

In summary, the analysis of variance results indicated variations in benthic invertebrate densities between sites and between and within sites on different sampling dates. The analysis of variance procedure showed that about 54 percent of the variation in mean densities was due to differences between sites, and about 33 percent of the variation was due to sampling date differences within and between sites. The remaining 13 percent was due to replication and sampling and analytical error. 
Benthic invertebrate densities were correlated with each measured waterquality constituent to determine if there was a significant relationship. At site $\mathrm{LGr}-1$, densities did not significantly correlate with any single tested water-quality constituent. However, the maximum $r$-square improvement model, adding water temperature, $\mathrm{pH}$, specific conductance, and dissolved oxygen to the correlation resulted in an $r$-square value of 1.0 . This correlation indicates that 100 percent of the variation in mean densities at site $\mathrm{LGr}-1$ was associated with these four water-quality constituents. This strong correlation may be a factor of small sample size.

At site LGr-2, mean benthic invertebrate densities were not significantly correlated with any of the tested water-quality constituents. The mode 1 showed the best improvement in $r$-square after addition of water temperature, $\mathrm{pH}$, dissolved oxygen, and specific conductance to a value of 0.79 indicating that 79 percent of the variation in density was associated with these four water-quality constituents.

At site $\mathrm{Gr}-1$, mean densities did not significantly correlate with any of the tested water-quality constituents. Adding all four water-quality constituents to the model increased the $r$-square to 0.54 indicating that 54 percent of the variation in mean densities was associated with water temperature, $\mathrm{pH}$, specific conductance, and dissolved oxygen.

\section{SUMMARY AND FUTURE MONITORING NEEDS}

\section{Trout Creek}

The density and number of benthic invertebrate taxa collected from Trout Creek increased from site $\mathrm{Tr}-1$ downstream to site $\mathrm{Tr}-3$. The diversity index decreased slightly downstream but failed to define adequately the differences in benthic communities of the Trout Creek sites. An examination of total community composition, including taxa, density and functional groups, indicated a significant difference in the benthic communities.

Density of organisms at site $\mathrm{Tr}-3$ was significantly different than the densities at sites $\mathrm{Tr}^{-1}$ and $\mathrm{Tr}-2$. Organism densities between sites $\mathrm{Tr}^{-1}$ and Tr-2 were not significantly different. The main reason for the difference in densities is that greater quantities of Diptera were collected at site $\mathrm{Tr}^{-3}$ than at the upstream sites. This difference in composition is not reflected in the diversity index because although the number of Diptera taxa and others increased downstream the density of organisms per taxa increased even more. 
Functional characteristics of the benthic community also differed between sites. Collectors were more abundant at the downstream site $(\mathrm{Tr}-3)$, and shredders and grazers were more abundant at the upstream sites. This trend was associated with the decrease in shredder-feeding caddisflies and increase in filter-feeding chironomids at site $\mathrm{Tr}-3$. Environmental or morphological changes in Trout Creek can account for much of this difference in benthic communities. The creek changes from a shaded headwater stream having an allochthonous food base, such as leaf litter, to a stream having an autochthonous food base of fine detrital organic material. The result is a shift from a well-balanced community composed more equally of several functional groups at sites $\mathrm{Tr}-1$ and $\mathrm{Tr}-2$ to a community comprised largely of collector-type organisms especially of the Diptera order at site Tr-3.

In summary, the study of benthic invertebrates in Trout Creek revealed a distinct difference in densities and taxa between the upstream sites ( $T r-1$, $\mathrm{Tr}-2)$ and the downstream site $(\mathrm{Tr}-3)$. The effect of the Edna Mine on the Trout Creek biota is difficult to evaluate. Sediment deposition and specific conductance were greater at site $\mathrm{Tr}-3$ than upstream. Much of this increase is due to agriculture, and because there has been mining in the basin for 40 years, the individual effect of coal mining as opposed to agriculture is difficult to determine.

Future monitoring of benthic invertebrates on Trout Creek at sites concentrated near the Edna Mine could aid in differentiating mining effects from agricultural effects. The Edna Mine probably will continue to mine coal downstream on Trout Creek, and one could incorporate other sites into a monitoring study as mining progresses. In addition, much of the variation in densities was due to sampling date, and little importance was associated with differences in replicate samples. Therefore, sampling at more frequent intervals while reducing the number of replicate samples would help reduce this variation.

\section{Fish Creek}

Density of benthic invertebrates collected from Fish Creek increased from sites $\mathrm{F}-1$ to $\mathrm{F}-2$ but was lowest at site $\mathrm{F}-3$. However, an analysis of variance test on mean densities showed that there was no significant difference between the three Fish Creek sites. There were, however, significant differences in mean densities on different sampling dates. Both the number of taxa and the corresponding diversity index decreased downstream. The diversity decreased because Diptera became more abundant downstream, and because there was an associated decrease in the number of other taxonomic groups.

The analysis of variance procedure also showed that there was a significant difference in mean number of taxa collected at site $\mathrm{F}-1$ compared with sites $\mathrm{F}-2$ and $\mathrm{F}-3$. Most of the variation in number of taxa was associated with sampling date. Functional group composition at site $\mathrm{F}-3$ was distinctly different from the functional group compositions at the upstream sites, because filtering-type organisms were more predominant. This trend is probably a result of land-use and environmental changes downstream. Although not measured, the sediment load probably increases downstream resulting in a 
food base of organic detrital material and a community of organisms that is adapted to filter food particles from the suspended sediments.

Benthic invertebrate densities at sites $F-2$ and $F-3$ were significantly correlated with dissolved oxygen. Specifically, as water temperature increases and dissolved oxygen decreases, there is an associated decrease in benthic invertebrate densities. The lower reach of Fish Creek is vulnerable to high summer water temperatures because of decreased shade or cover, and associated low dissolved oxygen concentrations may decrease below the minimum concentration required for maintenance of a well-balanced aquatic fauna.

Because sampling date was the major factor associated with variation in benthic invertebrate densities and taxa, future monitoring needs could include a greater frequency of sampling and a reduction in replicate sampling. A more thorough investigation of dissolved oxygen and water temperature correlations with benthic invertebrate densities would aid in determining whether densities could be estimated from water-quality measurements.

\section{Williams Fork}

Results of data analysis of benthic invertebrates collected from the Williams Fork indicated little variation in densities or taxa between sites. The river seems to have a healthy biotic community and a balanced taxonomic composition. Diptera dominated most frequently at the upstream site (WF-1), but they did not dominate the composition at site WF-4 downstream from the Williams Fork Strip No. 1 coal mine.

Mean densities at site WF-3 were significantly different from mean densities at sites WF-2 and WF-4. Most of the variation in densities, however, was due to variation in sampling dates. There were no significant differences in mean number of taxa between sites.

There were strong correlations of benthic invertebrate densities with water-quality constituents and properties especially at the main stem (WF-1, WF-3, WF-4) river sites. Dissolved oxygen and pH provided the best correlations with densities indicating the possibility of estimating benthic invertebrate densities from measurement of these water-quality constituents and properties.

There is no discernible effect of the Williams Fork Strip No. 1 coal mine on the stream biota. Settling ponds and a buffer zorie between the stream and spoil piles assure the maintenance of a stable benthic community. Because sampling date was the factor providing the most variation in benthic invertebrate densities and taxa, replicate sampling and number of sampling sites could be reduced in future monitoring; whereas, frequency of sampling could be increased. Correlation of water-quality data with benthic invertebrate densities needs to be investigated further to determine more clearly the actual relationship. 


\section{Canadian River}

Results of data analysis of benthic invertebrates collected from the Canadian River indicated differences in taxonomic composition between the two sites. The taxa were more diversified at site CR-1 than at site CR-2, and this was reflected in the species diversity index. Diptera comprised mainly of chironomids were much more abundant at the downstream site $(C R-2)$, where they dominated the composition on more than 50 percent of the sampling dates. The class 01 igochaeta, which has often been reported as a pollution-tolerant taxa, was also important at site $C R-2$. Taxonomic results were markedly different at site CR-1 where all groups except Coleoptera dominated the composition on at least one sampling date.

Differences in taxa between the sites are also. reflected in marked differences in functional groups. Approximately 89 percent of the organisms collected at site $\mathrm{CR}-2$ belong to the collector-type group, whereas, about 62 percent of the organisms at site CR-1 were of the collector-type. These results, combined with the remaining taxonomic information, indicate that the upstream site (CR-1) sustains a more stable, balanced community of organisms. However, the statistical results showed that there was no significant difference in number of taxa between sites, and sampling date was the greatest cause for variation in number of taxa.

Statistical results showed that there were no significant differences in mean densities between site $C R-2$ and site $C R-1$. In addition, 10 percent of the variation in mean densities was due to site, and 78 percent was due to sampling date. Therefore, sampling date is an important factor for variation of benthic invertebrate densities.

Statistical testing did not identify a strong correlation of waterquality measurements with benthic invertebrate densities. Ambient stream water quality has been well defined for the Canadian River (Kuhn, 1982); thus, future monitoring needs would preclude extensive monitoring of chemical water quality. Because differences in the benthic community are probably due to morphological and physical changes in the Canadian River, biological monitoring could be limited to quarterly monitoring unless land use, such as coal mining, drastically changes in the basin.

\section{Little Grizzly and Grizzly Creeks}

Composition of the major benthic invertebrate taxonomic groups varied only slightly between the Little Grizzly sites but was markedly different (because of increased percentage of Diptera) at the Grizzly Creek site (Gr-1). However, the functional group composition shifted between sites LGr-1 and LGr-2, and there was a marked decrease in grazer-type organisms and an associated increase in collector-type organisms (especially filterers) at site LGr-2. As in other streams in this study, this trend or shift in food base takes place because the physical character of the stream changes. 
Seasonal trends in percentage composition of taxonomic groups were similar at both Little Grizzly Creek sites, and Diptera were dominant only in the spring and early summer samples. At site $\mathrm{Gr}-1$, however, Diptera dominated the composition on all sampling dates except July 1980. This condition also is reflected in the lower mean diversity index of 2.97 calculated for site $\mathrm{Gr}^{-1}$.

Statistically, mean benthic invertebrate densities were significantly lower at site Gr-1 as compared to sites LGr-1 and LGr-2, and mean number of taxa at the Grizzly Creek $(\mathrm{Gr}-1)$ site was significantly lower than those at the Little Grizzly Creek sites. Most of the variation in mean densities and taxa was because of site differences. There were some correlations of benthic invertebrate densities with $\mathrm{pH}$, water temperature, dissolved oxygen, and specific conductance at the Little Grizzly and Grizzly Creek sites. This correlation suggests the possibility of estimating benthic invertebrate densities from field water-quality measurements. However, a larger sample size (greater frequency of sampling) may influence this relationship.

Presently, there is no coal mining or other development of energy resources in the basin. The results of this study could provide a basis for future monitoring should land use changes occur.

\section{REFERENCES CITED}

Brinkhurst, R. 0., and Cook, D. G., 1974, Aquatic Earthworms (Annelida: 01igochaeta), in Hart, C. W., Jr., and Fuller, Samuel, eds., Pollution ecology of freshwater invertebrates: New York, Academic Press, p. $143-156$.

Britton, L. J., 1979, Reconnaissance evaluation of surface-water quality in Eagle, Grand, Jackson, Pitkin, Routt, and Summit Counties, Colorado: U.S. Geological Survey Open-File Report 79-420, 285 p.

1983, Data compilation of benthic invertebrates collected from tributary streams of the Yampa and North Platte River basins, Colorado: U.S. Geological Survey Open-File Report 83-140, 99 p.

Cairns, John, Jr., and Dickson, K. L., 1971, A simple method for the biological assessment of the effects of waste discharges on aquatic bottom-dwelling organisms: Journal Water Pollution Control Federation, v. 43 , no. 5 , p. 755-772.

Canton, S. P., and Ward, J. V., 1977, Effects of coal mine drainage on macroinvertebrates of Trout Creek, Colorado: Fort Collins, Colorado State University, Environmental Research Paper 9, April 1977, 13 p. 1978, Environmental effects of western coal surface mining, Part II, The aquatic macroinvertebrates of Trout Creek, Colorado: Duluth, Minn., U.S. Environmental Protection Agency Ecological Research Series, EPA-600/3-78-095, $63 \mathrm{p}$.

1981, The aquatic insects, with emphasis on Trichoptera, of a Colorado stream affected by coal strip-mine drainage: The Southwestern Naturalist, v. 25, no. 4, p. 453-460.

Chadwick, J. W., and Canton, S. P., 1983, Coal mine drainage effects on a lotic ecosystem in Northwest Colorado, U.S.A.: Hydrobiologia, v. 107, p. 25-33. 
Colorado Division of Planning, 1979, Population estimates and projections: Colorado Population Reports, Series CP-25, no. $79(\mathrm{C})-1,18 \mathrm{p}$.

Cummins, K. W., and Klug, M. J., 1979, Feeding ecology of stream in vertebrates: Annual Review of ecology and systematics, v. 10, p. 147-172.

Elliott, J. M., 1971, Some methods for the statistical analysis of samples of benthic invertebrates: Freshwater Biological Association, Scientific Publication no. 25, 148 p.

Erdmann, C. E., 1941 (revised 1944), Preliminary report on the geology of the Coalmont district, Jackson County, Colorado: U.S. Geological Survey Open-File Report, $207 \mathrm{p}$.

Gaufin, A. R., Harris, E. K., and Walter, H. J., 1956, A statistical evaluation of stream bottom sampling data obtained from three standard samplers: Ecology, v. 37, no. 4, p. 643-648.

Goodnight, C. J., 1973, The use of aquatic macroinvertebrates as indicators of stream pollution: Transactions of the American Microscopical Society, v. 92 , no. 1,13 p.

Greeson, P. E., Ehlke, T. A., Irwin, G. A., Lium, B. W., and Slack, K. V., 1977, Methods for collection and analysis of aquatic biological and microbiological samples: U.S. Geological Survey Techniques of WaterResources Investigations, Book 5, Chapter A4, 332 p.

Guy, H. P., 1969, Laboratory theory and methods for sediment analysis: U.S. Geological Survey Techniques of Water-Resources Investigations, Book 5, Chapter C1, 58 p.

Harner-White Ecological Consultants, Inc., 1981, Aquatic biological survey of Fish, Foidel and Middle Creeks, Routt County, Colorado 1979-1981: Littleton, Colo., Harner-White Ecological Consultants, Inc., 35 p.

Jones, D. E., and Murray, D. K., 1976, Coal mines of Colorado--statistical data: Colorado Geological Survey Information Series 2, 27 p.

Kuhn, Gerhard, 1982, Statistical summaries of water-quality data for two coal areas of Jackson County, Colorado: U.S. Geological Survey Open-File Report 82-121, 23 p.

Odum, E. P., 1971, Fundamentals of ecology (3d ed.): Philadelphia, W. B. Saunders Co., 574 p.

SAS Institute Inc., 1982, SAS Users guide: Basics: Cary, North Carolina, SAS Institute Inc., $923 \mathrm{p}$.

Scherschligt, Jon, 1975, North Platte River basin water quality management plan: Denver, Colorado Department of Health, Water Quality Control Division, $83 \mathrm{p}$.

Speltz, C. N., 1976, Strippable coal resources of Colorado; Location, tonnage, and characteristics of coal and overburden: U.S. Bureau of Mines Information Circular 8713, $70 \mathrm{p}$.

Steele, T. D., Bauer, D. P., Wentz, D. A., and Warner, J. W., 1979, The Yampa River basin, Colorado and Wyoming--A preview to expanded coal-resource development and its impacts on regional water resources: U.S. Geological Survey Water-Resources Investigations 78-126, 133 p.; available from U.S. Department of Commerce, National Technical Information Service, Springfield, VA 22161, as Report PB-300 815.

U.S. Department of Agriculture, Agricultural Research Service, 1981, Agricultural surface-mined hydrology group research at Energy Fuels mine, Routt County, Colorado, Progress Report no. 2: Fort Collins, Colo., U.S. Department of Agriculture, Agricultural Research Service, 135 p. 
U.S. Department of Commerce, 1981, 1980 Census of population and housing, Colorado: Bureau of the Census, U.S. Department of Commerce District Offices, p. 7-1, 7-5.

U.S. Environmental Protection Agency, 1977, Quality criteria for water, 1976: Washington, D.C., U.S. Environmental Protection Agency, 256 p.

U.S. Geological Survey, 1981, Water resources data for Colorado--water year 1980: U.S. Geological Survey Water-Data Report C0-80-1, 535 p.

Ward, J. V., Canton, S. P., and Gray, L. J., 1978, The stream environment and macroinvertebrate communities: Contrasting effects of mining in Colorado and the eastern United States, in Thorp, J. H., and Gibbons, J. W., eds., Energy and Environmental Stress in Aquatic Systems: Springfield, Va., Department of Energy Symposium Series (Conf-771114), p. 176-187.

Wilhm, J. L., and Dorris, T. C., 1968, Biological parameters for water quality criteria: Bioscience, v. 18, p. 477-481.

Wilhm, J. L., 1970, Range of diversity index in benthic invertebrate populations: Journal Water Pollution Control Federation, v. 42, p. R221-R224. 